UNIVERSIDADE DE SÃO PAULO

ESCOLA DE ENGENHARIA DE LORENA

CLAUDIO DONATO DE OLIVEIRA SANTOS

Avaliação do emprego do arroz preto (Oryza sativa L.) submetido a hidrólise enzimática como adjunto na fabricação de cerveja 



\section{Avaliação do emprego do arroz preto (Oryza sativa L.) submetido a hidrólise enzimática como adjunto na fabricação de cerveja}

Dissertação apresentada à Escola de Engenharia de Lorena da Universidade de São Paulo para a obtenção do título de Mestre em Ciências do Programa de Pós Graduação em Biotecnologia Industrial, na Área de concentração: Microbiologia Aplicada

Orientador: Prof. Dr. João Batista de Almeida e Silva 
AUTORIZO A REPRODUÇÃO E DIVULGAÇÃO TOTAL OU PARCIAL DESTE TRABALHO, POR QUALQUER MEIO CONVENCIONAL OU ELETRÔNICO, PARA FINS DE ESTUDO E PESQUISA, DESDE QUE CITADA A FONTE.

Catalogação na Publicação

Biblioteca "Cel. Luiz Sylvio Teixeira Leite"

Escola de Engenharia de Lorena da Universidade de São Paulo

Santos, Claudio Donato de Oliveira

Avaliação do emprego do arroz preto (Oryza sativa L.) submetido à hidrólise enzimática como adjunto na fabricação de cerveja. / Claudio Donato de Oliveira Santos. - 2011.

75 p. : il.

Dissertação (Mestre em Ciências - Programa de Pós-Graduação em Biotecnologia Industrial na Área de Microbiologia Aplicada) - Escola de Engenharia de Lorena da Universidade de São Paulo.

Orientador: João Batista de Almeida e Silva.

1. Cervejas 2. Malte (Adjunto) 3. Amilase 4. Arroz preto 5. Levedura. I. Título 
À minha família e à Flavia, com amor, admiração e gratidão por vossa paciência, compreensão e apoio incondicionais. 



\section{AGRADECIMENTOS}

A Deus, Todo Poderoso, por todos os momentos de desafio e aprendizado proporcionados por Ele a mim. Muito obrigado.

Aos bons amigos, que residem nas esferas da Espiritualidade, que silenciosamente contribuem e nos dão forças para seguir pelos caminhos estreitos da vida. Muito obrigado.

Ao Prof. Dr. João Batista de Almeida e Silva, pelas lições, e pela valiosa oportunidade, confiança, orientação e ensinamentos transmitidos ao longo deste trabalho. Muito obrigado.

Ao Prof. Dr. Ismael Maciel de Mancilha, por todo o ensinamento e amizade sincera, e pelo apoio irrestrito a este trabalho. Muito obrigado.

À Prof ${ }^{a}$. Dr ${ }^{a}$ Maria Bernadete de Medeiros, pelo grande incentivo e apoio ao meu desejo de voltar a estudar. Muito obrigado.

Aos professores da EEL - Dr. Walter de Carvalho, pelo apoio inicial, ao me permitir assistir suas aulas de Bioquímica antes de prestar a prova do mestrado; $\mathrm{Dr}^{\mathrm{a}}$ Maria das Graças de Almeida Felipe, por todos os ensinamentos e por sua alegria constante; Dr. Arnaldo Marcio Ramalho Prata, pela amizade e ensinamento transmitido; Dr. Messias Borges Silva, pelo exemplo de didática e pela amizade de tanto tempo; $\mathrm{Dr}^{\mathrm{a}}$ Wilma Lucia Cardoso, pela sinceridade e por fazer de um assunto tão complicado, como Didática, se tornar tão prazeroso. A todos vocês que me abriram caminhos para a Ciência. Muito obrigado.

Aos professores Dr. Carlos Shigue, Dr. Hélcio José Izário Filho, Dr ${ }^{a}$ Ursula Lanfer Marquez, pelo apoio que tornou possível a realização deste trabalho. Muito obrigado. 
Aos bons amigos Juan Rivaldi, Fernando Moreira, Flavio Ferraz e Giovani Brandão, pela amizade verdadeira, pelos bons momentos compartilhados e pela troca produtiva de ideias. Muito obrigado.

Aos amigos e companheiros de brewing, Cléber Mateus Tomazi de Oliveira e Mário Martins; aos amigos da cervejaria: Beatriz Carvalho, Danilo Perucchi, Thais Caldas, Rodrigo Pitanga, à "agregada" Paula Bucharles, Ernesto, Larissa. Aos amigos da EEL, Tatiane Coutinho, Luanda Abreu, Adriele, Diego, Victor Tabosa, Paula Julião, Germano Siqueira, Cecéu Santi, Sergião Moreira (casadão) e Juliana Penido (casadona, esposa do casadão e futura mamãe), Carol Dell'Aquila, Bruno Guedes, João Paulo, Lívia Melo, Dani Cortez, Dani Garcia, Priscila Vaz, Priscila Maziero (iiihh!), Rafael Garcia, José Tavares (Zé Cobrinha), Naila Mori, Bruno Gambarato, Vinícius Fernandes (Jukebox), Rondinele Moutta, Robson Faria, Wiliam Vilar Garcia (Perigoso), Gina Seabra, Fernando Masarin, Fernandinha Carvalho, Daniela Gurpilhares, Guilherme Simões (Nerd), Wagner Freitas, Joseana Rocha, Levi Ezequiel (Asqueroso), e todos aqueles que conviveram comigo e me apoiaram nos momentos necessários. Muito obrigado.

Aos funcionários da EEL, Sandra Borges, Simone Colombo, Bruno Marton, Isnaldi Rodrigues, André Silva e Nadir Magalhães. Aos funcionários da Biblioteca, em especial Regina Horta, Dora, Joel, Nelson e Paulo, pela ajuda e compreensão. Aos técnicos, Cibele, Zé Cobrinha, Nicamor, Rita, Jussara, Brandão, Paulo Roberto (claaaaro!!). A todos os funcionários da oficina de manutenção da EEL, pela ajuda e amizade. Aos guardas patrimoniais da EEL, pela amizade e companhia. Aos funcionários da AFA, Paulão e Dani. Muito obrigado.

À Capes, pelas bolsas concedidas ao longo deste trabalho; à Malteria do Vale; pelo malte doado; à Wallerstein Com. e Ind., pela doação do lúpulo; à Prozyn, pelas enzimas concedidas; à WE Consultoria, pelas leveduras prontamente disponibilizadas; e em especial à Ruzene, pela doação do arroz preto utilizado no trabalho. Muito obrigado.

A todos aqueles que contribuíram, direta ou indiretamente, para a realização deste trabalho 


\section{RESUMO}

SANTOS, C. D. O. Avaliação do emprego do arroz preto (Oryza sativa L.) submetido a hidrólise enzimática como adjunto na fabricação de cerveja. 2011. $75 p$. Dissertação (Mestrado em Ciências) - Escola de Engenharia de Lorena, Universidade de São Paulo, 2011.

Segundo a legislação brasileira, em uma cerveja, parte do malte de cevada pode ser substituído por cereais maltados ou não, e por carboidratos de origem vegetal, transformados ou não, conhecidos como adjuntos. Os adjuntos tem por finalidade contribuir como fonte alternativa de substrato, por geralmente terem preços inferiores ao malte de cevada e proporcionar à bebida características sensoriais peculiares. Este trabalho teve como objetivo utilizar a quirera de arroz preto (Oryza sativa L.), que não apresenta valor comercial, com o propósito de aumentar a contribuição de açúcares deste adjunto em $45 \%$ no extrato de um mosto primitivo de uma cerveja. $\mathrm{O}$ arroz foi caracterizado em relação aos teores de amido total $(83,20 \% \pm 1,41$, b.s.) e suas frações, ao teor de metais e da temperatura de gelificação $\left(78,68^{\circ} \mathrm{C}\right)$. A $\alpha$-amilase termoestável utilizada no processo também foi caracterizada em relação ao teor de proteínas $(20,5 \pm 1,2$ $\mathrm{mg}$ de proteína/mL de extrato), atividade amilásica (112 $000 \mathrm{Ul} / \mathrm{mL}$ de extrato) e atividade específica (5 $463 \mathrm{Ul} / \mathrm{mg}$ de proteína). Foram otimizadas as condições de hidrólise em relação ao tempo de processamento e concentração da enzima, segundo um planejamento experimental fatorial completo $2^{2}$ com três pontos centrais e estudo rotacionado. A levedura (Saflager S-23) utilizada no processo foi selecionada por apresentar melhor desempenho fermentativo dentre 4 cepas avaliadas. Os ensaios de fermentação foram executados em escala de bancada e ampliados para a escala piloto, na qual foi obtida excelente eficiência de mosturação $(73,71 \% \pm 4,69)$. A cerveja obtida foi avaliada do ponto de vista sensorial e físico-químico. O processo apresentou bom rendimento fermentativo $(0,37 \pm 0,04 \mathrm{~g} / \mathrm{g})$, eficiência de fermentação $(72,48 \% \pm 7,61)$ e produtividade em álcool $\left(0,32 \mathrm{~g} \cdot \mathrm{L}^{-1} \cdot \mathrm{h}^{-1} \pm 0,02\right)$. Concluiu-se que o processo pode resultar num produto com bom rendimento e características sensoriais muito intensas e agradáveis, similar a uma cerveja forte, consumida tipicamente durante o inverno.

Palavras-chave: Malte (Adjunto). Amilase. Arroz preto. Levedura. Cervejas. 


\begin{abstract}
SANTOS, C. D. O. Assessment of the use of black rice (Oryza sativa L.) submitted to enzymatic hydrolysis as adjunct on beer manufacturing. 2011. 75p. Dissertation (Master of Science) - Escola de Engenharia de Lorena, Universidade de São Paulo, 2011.

As cited on Brazilian legislation, in a beer, part of the malt can be substituted by malted or non-malted cereals, and by carbohydrates from vegetal sources, called adjuncts. Adjuncts have the purpose of contributing as an altenative and cheaper source of sugars, when compared to barley malt, and provide peculiar sensory characteristics. This work aimed to use the black rice (Oryza sativa L.) grits, which does not have economic value, and use this raw material on the proportion of $45 \%$ on the primitive extract of a beer. On black rice, it was quantified starch $(83,20 \% \pm$ 1,41, d.b.) and metal content, and measured the gelatinization temperature $(78,68$ ${ }^{\circ} \mathrm{C}$ ). The enzyme (Brautec Alfa-TF) used in this work was characterized on protein content $(20,5 \pm 1,2 \mathrm{mg}$ protein $/ \mathrm{mL}$ de enzyme extract), activity $(112000 \mathrm{IU} / \mathrm{mL}$ of extract) and specific activity (5463 IU/mg of protein). The enzymatic hydrolysis conditions were optimized using a full factorial $2^{2}$ central composite design with star points aiming at it the sugar concentrations response on hydrolysate regarding the factors: enzyme concentration and processing time at $95{ }^{\circ} \mathrm{C}$. The yeast strain was selected among 4 strains regarding the factors: alcohol yield $(\mathrm{g} / \mathrm{g})$, fermentation efficiency $(\%)$ and alcohol productivity $\left(\mathrm{g} \cdot \mathrm{L}^{-1} \cdot \mathrm{h}^{-1}\right)$. Assays were carried out on benchtop scale and scaled up to pilot scale, and showed excellent mashing efficiency $(73,71 \% \pm 4,69)$. Beer was evaluated physico-chemically and sensorially and showed a good alcohol yield $(0,37 \pm 0,04 \mathrm{~g} / \mathrm{g})$, fermentation efficiency $(72,48 \% \pm 7,61)$ and alcohol productivity $\left(0,32 \mathrm{~g} \cdot \mathrm{L}^{-1} \cdot \mathrm{h}^{-1} \pm 0,02\right)$. It could be concluded that this process can result in product with good yield and very intense and pleasant sensory characteristics, similar to stronger beers, tipically consummed during the winter.
\end{abstract}

Keywords: Malt (Adjunct). Amylase. Black rice. Yeast. Beer. 


\section{LISTA DE FIGURAS}

Figura 1. Vias de metabolização apresentadas por S. cerevisiae. Fermentação alcoólica e respiração. Adaptado de Nelson; Cox (2004).

Figura 2. Fermentação alcoólica. Adaptado de Nelson; Cox (2004)......

Figura 3. Arroz preto integral (a), arroz branco integral (b), arroz branco polido (c), quirera de arroz preto $(d)$.

Figura 4. Estrutura de uma molécula de amilose. Adaptado de Andrade (2007). .28

Figura 5. Estrutura de uma molécula de amilopectina. Adaptado de Andrade (2007). .28

Figura 6. Gráfico da mosturação aplicada ao hidrolisado enzimático de arroz preto e malte. Adaptado de Tschope (2001)..... 38

Figura 7. Formulário utilizado no Teste de Comparação Pareada e Teste de Aceitação. 45

Figura 8. Gráfico comparativo do teor de alguns metais entre tipos diferentes de arroz 49

Figura 9. Consumo de açúcares durante o experimento de seleção de leveduras.. .52

Figura 10. Produção de álcool durante o experimento de seleção de leveduras. .53

Figura 11. Consumo de açúcares e produção de álcool durante as $168 \mathrm{~h}$ de fermentação do lote 1 .

Figura 12. Consumo de açúcares e produção de álcool durante as $144 \mathrm{~h}$ de fermentação do lote 2. 60

Figura 13. Consumo de açúcares e produção de álcool durante as $132 \mathrm{~h}$ de fermentação do lote 3. 60

Figura 14. Gráfico comparativo da produção de álcool durante as 3 fermentações. 60

Figura 15. Gráfico comparativo do consumo de açúcares durante as 3 fermentações. 60

Figura 16. Cerveja produzida utilizando o hidrolisado de arroz preto como adjunto. 61

Figura 17. Número de células suspensas em relação à produção de álcool durante a fermentação...

Figura 18. Distribuição dos provadores por faixa etária e sexo. 62 


\section{LISTA DE TABELAS}

Tabela 1 - Atributos do grão de cevada maltado e não-maltado. Adaptado de Kunze (1996)........16

Tabela 2 - Composição centesimal dos lúpulos comerciais. Adaptado de Hough (1985)..............18

Tabela 3 - Distribuição do consumo de água no processo cervejeiro. (KUNZE, 1996)...................19

Tabela 4 - Composição centesimal, teor de compostos fenólicos, teor de ferro, e valor calórico de diferentes tipos de arroz (base seca). Adaptado de Bassinelo et al (2008) ...................27

Tabela 5 - Composição Nutricional do Arroz preto IAC 600. Adaptado de IAC (2011)..................27

Tabela 6 - Temperatura, pH e alvo de ação das enzimas (TSCHOPE, 2001)................................31

Tabela 7 - Principais enzimas amilolíticas comerciais. Adaptado de Andrade (2007)....................33

Tabela 8 - Matriz do planejamento fatorial completo $2^{2}$ com três ensaios no ponto central e mais

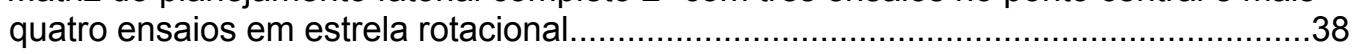

Tabela 9 - Cepas de leveduras utilizadas no experimento........................................................

Tabela 10 - Comparação entre as atividades declaradas e a atividade medida experimentalmente.

Tabela 11 - Tabela comparativa de temperaturas finais de gelificação do amido em 10 variedades de arroz.

Tabela 12 - Teores de metais na amostra de quirera de arroz preto. . .49

Tabela 13. Teores de amido total e amilose aparente em quirera de arroz preto IAC-600 .50

Tabela 14. Valores de extrato e rendimento obtidos nas diversas condições de hidrólise estudadas.

Tabela 15. Repetições da condição escolhida para a hidrólise da quirera de arroz........................53

Tabela 16. Parâmetros fermentativos após 48 horas de fermentação.............................................53

Tabela 17. Análises feitas com os mostos dos 3 lotes produzidos e a média dos resultados.........56

Tabela 18. Perfil de carboidratos no mosto com arroz preto, comparado com o perfil obtido por Andrade, (2007)

Tabela 19. Perfil centesimal de carboidratos no mosto. . .57

Tabela 20. Análises físico-químicas dos 3 lotes de cerveja com $45 \%$ de arroz preto ao final da fermentação.

Tabela 21. Parâmetros Fermentativos do estudo, em comparação com Andrade (2007)..............60

Tabela 22. Teste de aceitação, com as respostas divididas entre homens e mulheres..................64

Tabela 23. Teste de preferência, entre os provadores que comprariam a cerveja.........................64

Tabela 24. Notas médias das amostras entre os consumidores que comprariam a cerveja...........65 


\section{SUMÁRIO}

1. INTRODUCC̃̃O

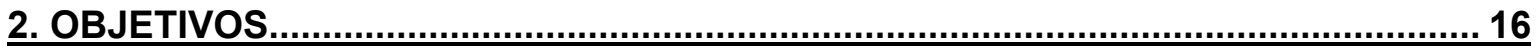

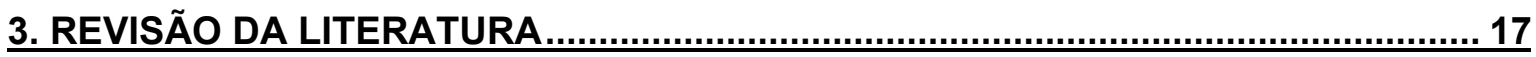

3.1.MATÉRIAS PRIMAS ................................................................................ 17

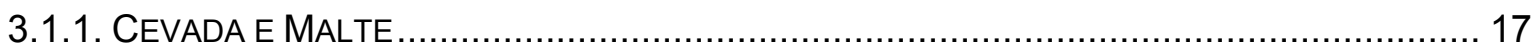

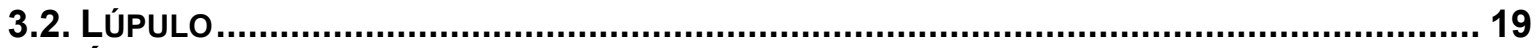

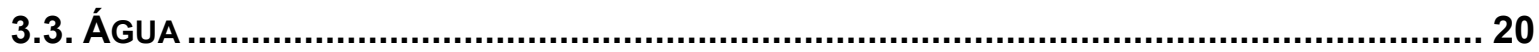

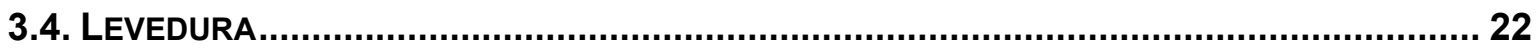

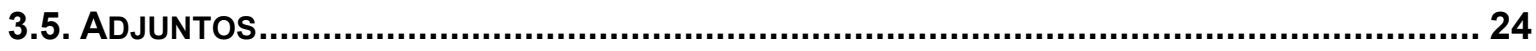

3.5.1. ARROZ PRETO - IAC 600 (ORYZA SATIVA) COMO ADJUNTO ................................... 27

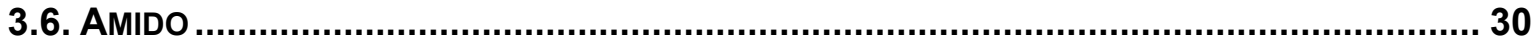

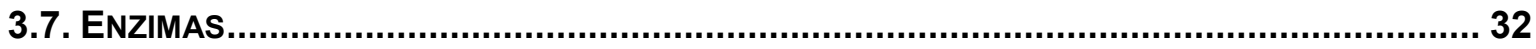

4. MATERIAL E MÉTODOS …………………

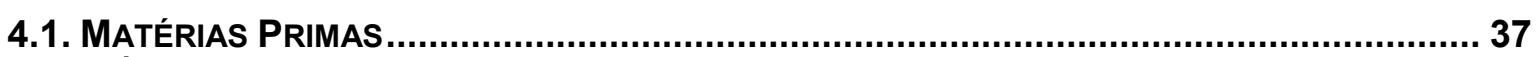

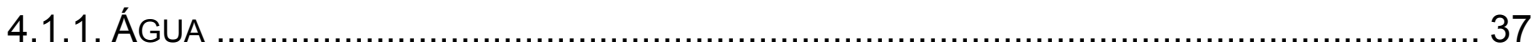

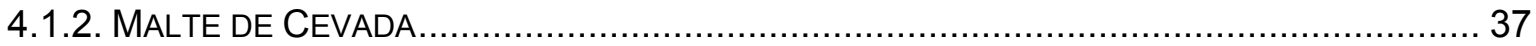

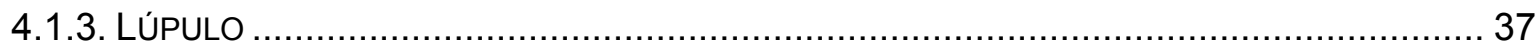

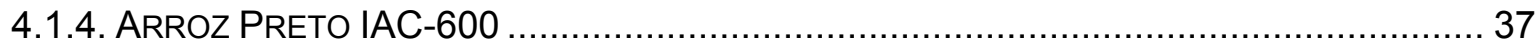

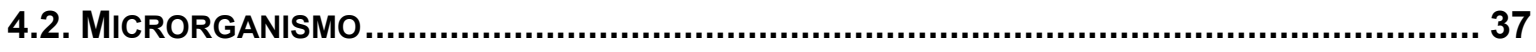

4.3. CARACTERIZAÇÃO DO ARROZ PRETO IAC-600 .................................................... 38

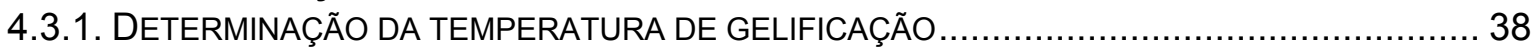

4.3.2. DETERMINAÇÃO DO TEOR DE METAIS NO ARROZ PRETO ………............................. 38

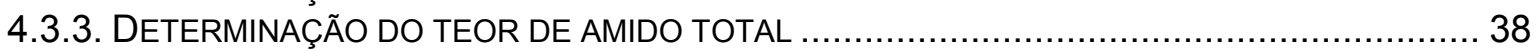

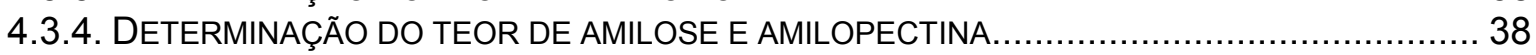

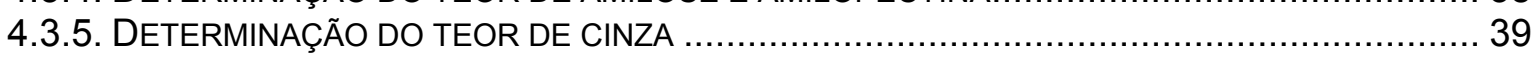

4.4. CARACTERIZAÇÃO DA $\alpha$-AMILASE TERMOESTÁVEL ……............................................ 39

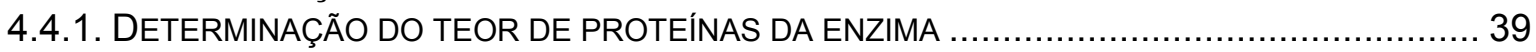

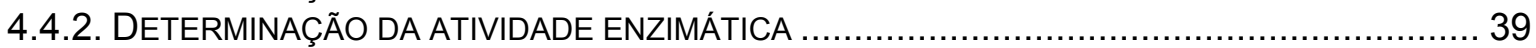

4.4.3. DETERMINAÇÃO DA ATIVIDADE ENZIMÁTICA ESPECCIFICA....................................... 40

4.5. DETERMINAÇÃO DA MELHOR CONDIÇÃO DE HIDRÓLISE DO ARROZ PRETO …...................40 40

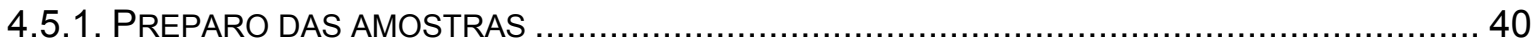

4.6. AVALIAÇÃO DA EFICIÊNCIA DA MOSTURAÇÃO COM ARROZ PRETO E MALTE E MOSTO PURO

MALTE. .............................................................................................................. 42

4.7. SELEÇÃo dA CEPA DE SACCHAROMYCES CEREVISIAE. …......................................... 42

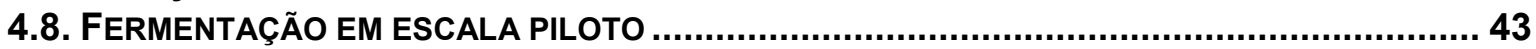

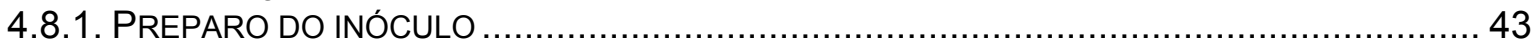

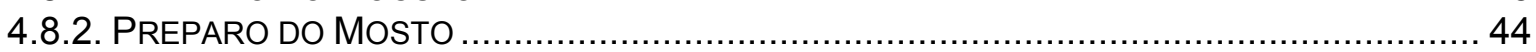

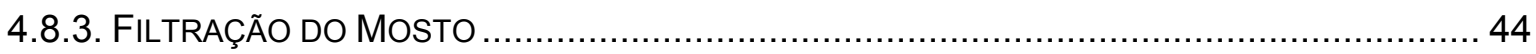

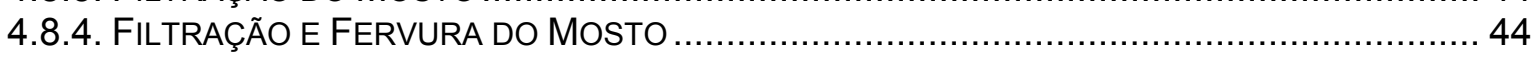

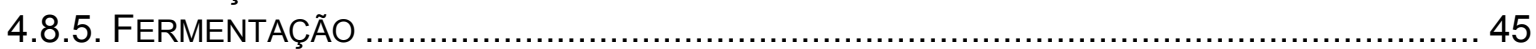

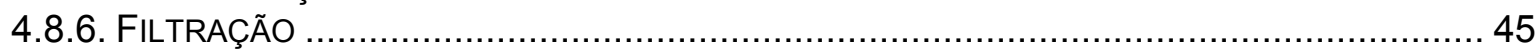

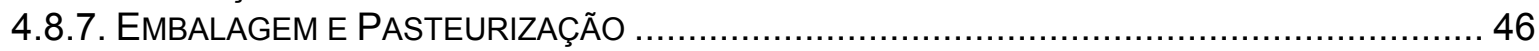

4.9. ACOMPANHAMENTO ANALÍTICO DA FERMENTAÇÃO ……..........................................46

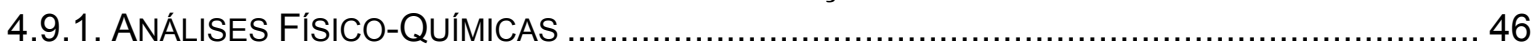

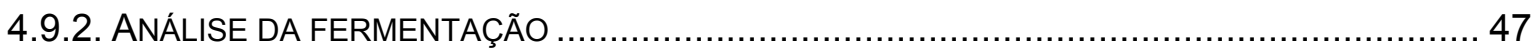

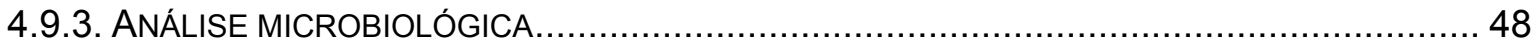

4.10. ANÁLISE SENSORIAL ..................................................................................... 48

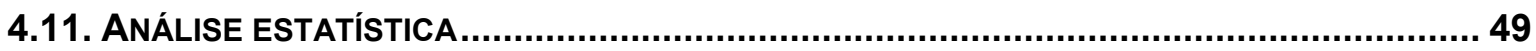




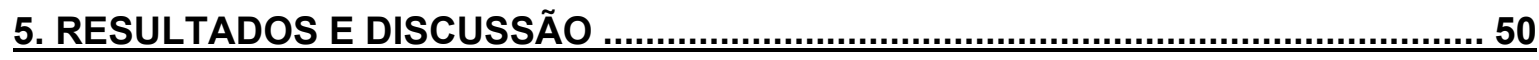

5.1. CaracterizaÇão da $\alpha$-Amilase termoestável Prozyn Brautec Alfa-TF ${ }^{\circledR}$......... 50

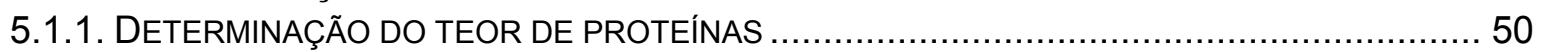

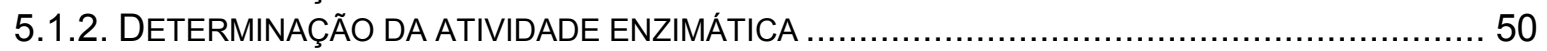

5.2. CARACTERIZAÇÃo do ARROZ PRETO IAC-600 (ORYZA SATIVA) .................................. 51

5.2.1. TEMPERATURA DE GELIFICAÇÃO DO ARROZ PRETO .............................................. 51

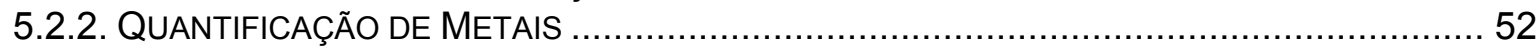

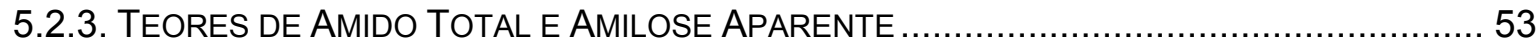

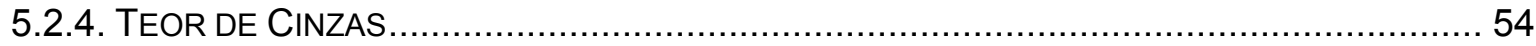

5.3. DETERMINAÇÃO DA MELHOR CONDIÇÃO DE HIDRÓLISE ENZIMÁTICA DO ARROZ PRETO ... 54

5.4. ESCOLHA DA CEPA DE SACCHAROMYCES CEREVISIAE ............................................... 55

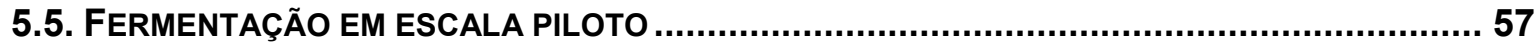

5.5.1. ANÁLISE FÍSICO-QUÍMICA DO MOSTO COM 45\% DE ARROZ PRETO .............................. 57

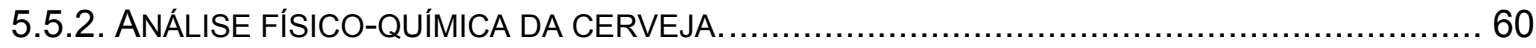

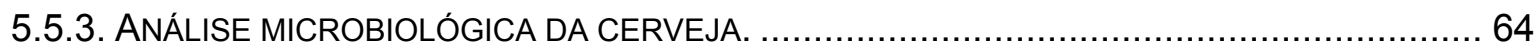

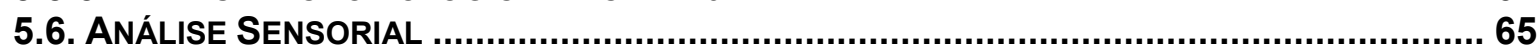

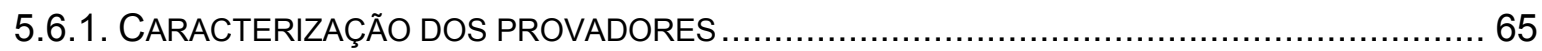

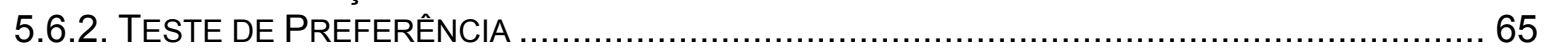

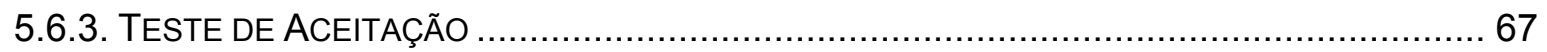

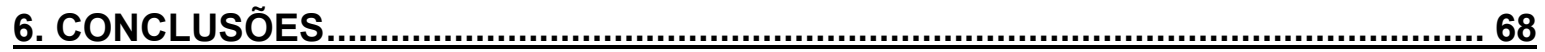

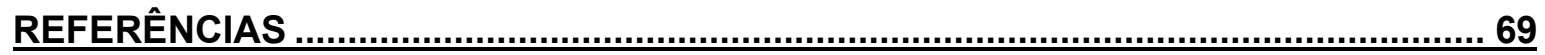




\section{INTRODUÇÃO}

O consumo de cerveja no Brasil quase dobrou nas duas últimas décadas, aumentando de 5,5 bilhões de litros em 1990 para 10,3 bilhões de litros em 2007, quantidade superada apenas pela China, com 35 bilhões de litros, Estados Unidos, com 23,6 bilhões de litros e Alemanha, com 10,7 bilhões de litros. Em 2010, a expectativa da indústria brasileira era ultrapassar os 12 bilhões de litros.

O setor cervejeiro é responsável por mais de 150 mil empregos diretos e indiretos no país, com investimentos crescentes a cada ano. Nos últimos cinco anos, as indústrias cervejeiras investiram mais de $\mathrm{R} \$ 3$ bilhões, com 10 novas plantas industriais, além de ampliações e modernizações das fábricas já existentes.

Além do aumento no consumo, no Brasil existe uma demanda crescente por cervejas especiais, sejam elas fruto da combinação de ingredientes de melhor qualidade ou feitas utilizando adjuntos não convencionais, tais como mel, fécula de mandioca, e rapadura, entre outros. A elaboração de cervejas utilizando adjuntos especiais é uma forma de reduzir o custo de fabricação da cerveja, em alguns casos e em outros casos para proporcionar características sensoriais singulares ao produto.

Tendo em vista esta tendência do mercado nacional, um dos adjuntos que pode ser utilizado para obtenção de cerveja com custo de produção mais econômico e com características especiais é a quirera de arroz preto. Esta variedade de arroz adaptada ao solo e clima brasileiro pelo Instituto Agronômico de Campinas, durante seu beneficiamento sofre grande perda pela quebra dos grãos, com isso estes resíduos denominados de quirera são utilizados apenas como ração animal, não gerando receita como os grãos inteiros.

Desta forma, além de contribuir para o desenvolvimento de um processo cervejeiro mais viável economicamente e agregar valor a este subproduto, este trabalho dá continuidade à linha de pesquisa do Grupo de Microbiologia Aplicada e Bioprocessos do Departamento de Biotecnologia da Escola de Engenharia de Lorena - USP, iniciada em 1997, com o apoio da Fapesp, CAPES e CNPq, visando o estudo de inovações tecnológicas na produção de bebidas alcoólicas. 


\section{OBJETIVOS}

O objetivo geral do trabalho é contribuir para o desenvolvimento de uma tecnologia de produção de cerveja empregando arroz preto como adjunto.

Os objetivos específicos deste trabalho são:

- Caracterizar o arroz preto que será utilizado como adjunto no processo cervejeiro;

- Caracterizar a enzima utilizada no processo de hidrólise do arroz preto;

- Determinar as melhores condições de hidrólise do arroz preto, utilizando $\alpha$ amilase termoestável;

- Selecionar a levedura cervejeira com melhor desempenho na fermentação de um mosto com $45 \%$ de arroz preto no extrato primitivo, em escala laboratorial;

- Obter a cerveja utilizando $45 \%$ de arroz preto no extrato primitivo, em escala piloto;

- Avaliar as características físico-química e sensorial da bebida obtida. 


\section{REVISÃO DA LITERATURA}

\subsection{Matérias Primas}

A cerveja é uma solução que contem $\mathrm{CO}_{2}$, etanol, sais inorgânicos e compostos orgânicos, preparada a partir de malte, água potável, lúpulo e leveduras, podendo ainda, ser utilizadas outras matérias primas amiláceas e açúcaradas como adjunto do malte (CARVALHO; BENTO; ALMEIDA e SILVA, 2007).

\subsubsection{Cevada e Malte}

A cevada é uma gramínea cultivada no mundo todo, porém melhor adaptada ao clima temperado. As espécies utilizadas para maltar são a Hordeum vulgare L. e a Hordeum distichon L., que visualmente se diferenciam por apresentarem ramos com seis e com duas fileiras de grãos, respectivamente (FREEMAN, 2002). Um grão de cevada contém, em média, $11 \%$ de casca, $2,5 \%$ de testa e pericarpo, $4,5 \%$ de aleurona, $80 \%$ de endosperma, e $2 \%$ de embrião, em relação à massa seca (PALMER, 2006).

As partes principais dos grãos de cevada são:

Endosperma: Parte do cereal que compreende o pericarpo, a testa, a aleurona, e o tecido amiláceo. O tecido amiláceo representa a maior estrutura do cereal e é formada por milhares de células. Além do amido, o endosperma amiláceo contém proteínas, como a hordeína e a glutelina, que constituem a maior parte da matriz protéica do endosperma, $40 \%$ e $30 \%$ respectivamente, seguidos pela albumina com $20 \%$ e globulinas $10 \%$ (PALMER, 2006).

Aleurona: É um tecido que contém de duas a três camadas de células, que cobre o endosperma amiláceo e se estende sobre o embrião. Durante a maltagem, o ácido giberélico secretado pelo embrião germinado induz as células da aleurona a produzir enzimas que degradam o endosperma (PALMER, 2006).

Embrião: é a parte que contém as células vivas da semente, rica em proteínas e ácidos nucléicos. Quando em condições propícias de temperatura e umidade, é responsável pelo processo de germinação, no qual degrada o amido e obtém energia para seu crescimento. A habilidade do grão de cevada de germinar é o ponto crucial do processo de maltagem. (FREEMAN, 2002). 
O malte é o produto da germinação controlada das sementes de cevada para o emprego industrial, utilizado na fabricação de cerveja, uísques, farináceos e outros produtos alimentícios (VENTURINI FILHO; CEREDA, 2001). No Brasil, quando o malte é de cevada, é chamado apenas de malte, e quando é de outros cereais, deve ser denominado "malte de..." seguido pelo nome do cereal (BRASIL, 2009). A maltagem é um processo que visa desenvolver as enzimas necessárias para a hidrólise dos grãos de amido contidos no cereal. Este processo é constituído por três etapas: maceração, germinação e secagem (KUNZE, 1996).

A Tabela 1 apresenta as diferenças entre os grãos de cevada antes e depois da maltagem, principalmente no que se refere ao seu conteúdo enzimático e sua atividade.

Tabela 1 - Atributos do grão de cevada maltado e não-maltado. Adaptado de Kunze (1996)

\begin{tabular}{lcc}
\hline \multicolumn{1}{c}{ Atributo } & Cevada & Malte \\
\hline Massa do grão (mg) & $32-36$ & $29-33$ \\
Umidade (\%) & $10-14$ & $4-6$ \\
Amido (\%) & $55-60$ & $50-55$ \\
Açúcares (\%) & $0,5-1,0$ & $8-10$ \\
Nitrogênio Total (\%) & $1,8-2,3$ & $1,8-2,3$ \\
N solúvel / N total (\%) & $10-12$ & $35-50$ \\
Poder diastásico, ( ${ }^{\circ}$ Lintner) & $50-60$ & $100-250$ \\
$\alpha$ - amilase, DU & Traços & $30-60$ \\
\hline
\end{tabular}

A eficiência da maltagem é medida através de três parâmetros: citólise, proteólise, e amilólise.

A citólise descreve a degradação da parede das células que armazenam o amido no endosperma, e sua extensão pode ser medida através de fatores como o teor de $\beta$-glucana. Uma degradação mais extensa destes compostos durante a maltagem facilita o ataque enzimático ao amido no curso da brassagem. O teor de $\beta$-glucana é considerado o melhor indicador de qualidade do malte e, juntamente com a friabilidade do malte e a viscosidade do mosto, mostra a extensão da modificação da parede celular (NOOTS, 2001).

A proteólise descreve a degradação das proteínas do malte, e sua transferência para o mosto, em compostos de baixo, médio e alto peso molecular. A hidrólise das proteínas não deve ser excessiva, nem tão baixa, para que não 
prejudique a fermentação. A baixa hidrólise das proteínas pode não fornecer os compostos nitrogenados necessários ao crescimento das leveduras e resultar em baixa propagação das leveduras e o desenvolvimento de subprodutos indesejáveis na fermentação, como o diacetil. (KREISZ, 2009).

O grau de amilólise representa quanto o malte pode render em termos de açúcares fermentáveis, entre os parâmetros medidos devemos destacar o teor de extrato, o grau de atenuação final, e o poder diastático como uma estimativa da atividade da $\alpha$-e $\beta$-amilases.

\subsection{Lúpulo}

O lúpulo (Humulus lupulus L.) é uma planta pertencente à familia Cannabinaceae, que apesar do parentesco com a Cannabis, não contém substâncias alucinógenas. O lúpulo tem caráter dióico, ou seja, apresenta flores masculinas e femininas em indivíduos diferentes, não havendo, assim, planta hermafrodita (VENTURINI FILHO; CEREDA, 2001).

$O$ interesse industrial recai sobre a planta feminina, mais precisamente sobre as flores, na forma de cone, e seus frutos (VENTURINI FILHO; CEREDA, 2001). Estas inflorescências são utilizadas na indústria cervejeira para conferir amargor e aroma à cerveja, proveniente de óleos essenciais e resinas amargas contidas nas glândulas de lupulina (LAMAGNA, 2004; KUNZE, 1996). Além do aroma e amargor, o lúpulo apresenta ação antisséptica, pois os iso- $\alpha$-ácidos são bacteriostáticos, e contribuem para a estabilidade do sabor e espuma da cerveja (VENTURINI FILHO; CEREDA, 2001).

As substâncias amargas não são apenas um tipo único de composto químico, mas uma mistura de vários ácidos e resinas que se modificam como resultado dos efeitos do oxigênio, calor e umidade sobre estes compostos (HOUGH, 1985).

A Tabela 2 apresenta dados de composição centesimal dos lúpulos comerciais, sendo os mais relevantes os óleos essenciais e as resinas. 
Tabela 2 - Composição centesimal dos lúpulos comerciais. Adaptado de Hough (1985)

\begin{tabular}{lc}
\hline Componente & Concentração (\%) \\
\hline Água & 10,0 \\
Resinas Totais & 15,0 \\
Óleos Essenciais & 0,5 \\
Taninos & 4,0 \\
Monossacarídeos & 2,0 \\
Pectina & 2,0 \\
Aminoácidos & 0,1 \\
Proteína Bruta & 15,0 \\
Lipídeos e ceras & 3,0 \\
Cinzas & 8,0 \\
Celulose, lignina, etc & 40,4 \\
Total & 100,0 \\
\hline
\end{tabular}

A propriedade mais importante da resina é o valor de amargor que ela pode conferir à cerveja (KUNZE, 1996). Os principais compostos presentes nas resinas macias são os ácidos amargos, que podem ser divididos em a-ácidos (3-17\%) e $\beta$-ácidos (2-7\%). Os homólogos dos $\alpha$-ácidos e $\beta$-ácidos são denominados humulonas e lupulonas, respectivamente (KROTTENTHALER, 2009).

Os $\alpha$-ácidos proporcionam 9 vezes mais amargor para a cerveja que os $\beta$ ácidos presentes no lúpulo. O amargor depende, principalmente, da extensão em que os $\alpha$-ácidos são isomerizados a iso- $\alpha$-ácidos. Esta conversão ocorre quando a mistura é submetida a uma ebulição por tempo prolongado ou a um tratamento alcalino. (KUNZE, 1996).

Outros compostos de interesse são os óleos essenciais contidos na flor e que, apesar de desejáveis são muito voláteis, entre 96 e 98\% do seu conteúdo se perde durante a fervura, o restante, mesmo em baixa concentração, sofre oxidação e confere o caráter aromático do lúpulo à cerveja (TSCHOPE, 2001).

\section{3. Água}

A água é o ingrediente em maior proporção na cerveja, mais de $90 \%$ do produto final (TAYLOR, 2006). Porém, esta quantidade representa apenas de 16 a $20 \%$ do total de água utilizada no processo de fabricação. Em média, para cada hectolitro de cerveja produzida, são consumidos 6 hectolitros de água, de acordo com a Tabela 3. (FILLAUDEAU, 2005; TAYLOR, 2006) 
Tabela 3 - Distribuição do consumo de água no processo cervejeiro. (KUNZE, 1996)

\begin{tabular}{lc}
\hline \multicolumn{1}{c}{ Tipo de água } & Volume (hL) \\
\hline Água de brassagem & 2,7 \\
Água de processo & 2,1 \\
Água de uso geral & 1,0 \\
Água de serviço & 0,2 \\
\hline
\end{tabular}

A água de brassagem contribui diretamente como um ingrediente da cerveja e requer tratamento para que se enquadre nos parâmetros de qualidade necessários para ser usada no processo, pois alguns de seus atributos tem influência direta na qualidade da cerveja, tais como, dureza, $\mathrm{pH}$ e carga bacteriana, entre outros (TAYLOR, 2006).

No processo cervejeiro, podem ser usados dois tipos de água, a de superfície, proveniente de rios e lagos, e a água subterrânea, proveniente de poços. As águas de superfície estão sempre sujeitas a maiores variações na qualidade e na composição, devido à exposição ao ambiente, poluição, contaminação por efluentes orgânicos e inorgânicos. As águas subterrâneas tem melhor qualidade em relação à superficial, e por este motivo são as mais utilizadas em cervejarias. Estas águas percolam através do solo e apresentam menos partículas suspensas e menor chance de contaminação por microrganismos (KUNZE, 1996; TAYLOR, 2006).

Apesar de potável, nas grandes indústrias a água é tratada, com o objetivo de manter a uniformidade da qualidade, e este processo ocorre em três estágios: remoção de material em suspensão, de material dissolvido e de microrganismos (KUNZE, 1996).

A dureza é um parâmetro primordial na qualidade da água, que se conceitua como o teor de íons cálcio e magnésio presentes na água. (KUNZE, 1996; TAYLOR, 2006; KROTTENTHALER, GLAS, 2009). Outros íons possivelmente presentes na cerveja apresentam influência direta na sua qualidade sensorial, fazendo com que a cerveja apresente gosto salgado, amargo, doce ou azedo, dependendo do íon e sua concentração (TAYLOR, 2006). 


\subsection{Levedura}

Leveduras são organismos unicelulares pertencentes ao reino Fungi, que se reproduzem vegetativamente por brotamento (TENGE, 2009).

No passado, a nomenclatura das espécies de leveduras variava de acordo com características fenotípicas, nutricionais ou outros critérios que resultavam em classificações distintas, fazendo com que fossem classificadas em diferentes espécies, tais como S. uvarum, S. cerevisiae, S. carlsbergensis. Porém, análises feitas com o DNA destas espécies revelou bases comuns entre elas, isso fez com que os taxonomistas designassem todas as cepas usadas na produção de cerveja como Saccharomyces cerevisiae (RUSSEL, 2006).

As leveduras são classificadas de acordo com o seu comportamento durante o processo fermentativo, podendo decantar ao fundo do fermentador, neste caso as leveduras são classificadas como tipo lager, conhecidas como leveduras de "baixa fermentação", em outro caso, as leveduras podem flutuar na superfície do mosto em fermentação, então classificadas como leveduras tipo ale, chamadas de leveduras de "alta fermentação" (HOUGH, 1985).

As leveduras de alta fermentação formam cadeias de células que retêm o $\mathrm{CO}_{2}$ formado durante a fermentação, que faz com que os aglomerados flutuem no tanque. As leveduras de baixa fermentação tendem a flocular, precipitando-se no final do processo fermentativo. A grande maioria das cervejarias no Brasil utilizam leveduras de baixa fermentação no seu processo devido a melhor coleta da levedura após a fermentação e filtrabilidade da cerveja. (TSCHOPE, 2001)

Segundo Stewart (2000), as características de sabor e aroma da cerveja são determinadas na maior parte pelo tipo de levedura utilizada. Embora o etanol seja o principal produto de metabolismo da levedura durante a fermentação, este tem pequeno impacto sobre o sabor da cerveja. Vários fatores podem influenciar no sabor da cerveja, incluindo: a cepa de levedura, a temperatura e o pH de fermentação, o tipo e o nível de adjunto, o modelo de fermentador e a concentração do mosto.

As apresentações comerciais de leveduras cervejeiras podem ser secas ou na forma de creme de leveduras. A levedura seca apresenta as vantagens de ser mais estável, ser mais fácil de dosar e ter vida útil de 24 meses após fabricação, 
se conservada em condições satisfatórias, enquanto no creme de leveduras a vida útil não excede 90 dias (FERMENTIS, 2010)

O metabolismo das leveduras pode ser tanto respiratório quanto fermentativo, dependendo da presença ou ausência de $\mathrm{O}_{2}$. Quando na presença de oxigênio, a levedura tende a respirar, metabolizando a glicose pela Via Glicolítica ou Embden Meyerhof Parnas (EMP) e, posteriormente, oxidando o ácido pirúvico resultante pela via do ácido cítrico, gerando como subprodutos, $\mathrm{CO}_{2}, \mathrm{H}_{2} \mathrm{O}$ e energia suficiente para que a célula sobreviva e se divida. Em anaerobiose, a célula metaboliza a glicose pela via EMP e oxida os produtos pela via fermentativa alcoólica, gerando etanol, $\mathrm{CO}_{2}$ e energia o suficiente para sua sobrevivência. O destino da glicose e a via fermentativa alcoólica estão ilustrados nas figuras 1 e 2 (NELSON; COX, 2004).

\section{Glicose}

\section{Glicólise}

(10 Reações

Sucessivas)

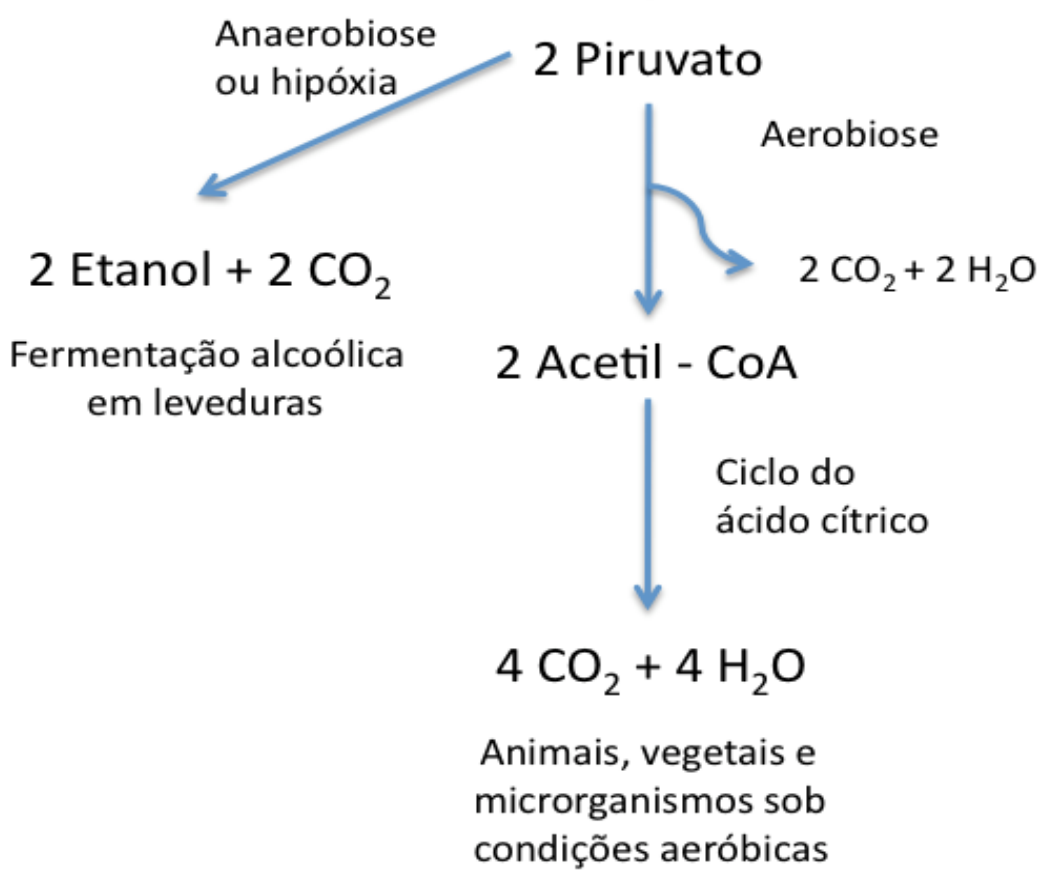

Figura 1. Vias de metabolização apresentadas por S. cerevisiae. Fermentação alcoólica e respiração. Adaptado de Nelson; Cox (2004). 


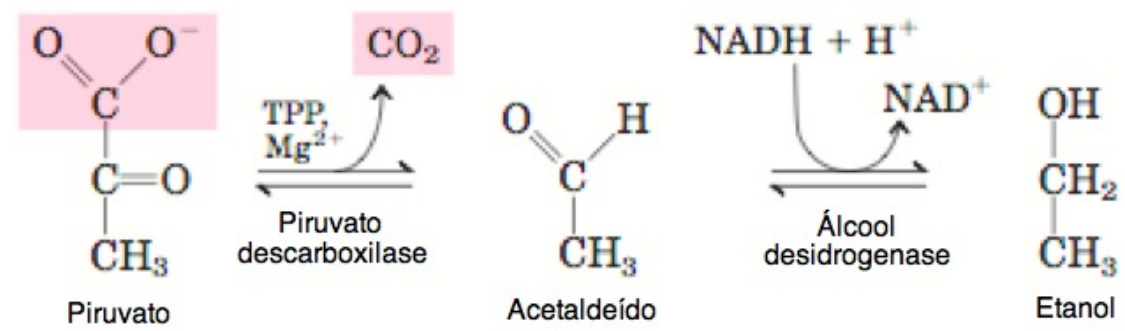

Figura 2. Fermentação alcoólica. Adaptado de Nelson; Cox (2004).

\subsection{Adjuntos}

Os adjuntos na produção de cerveja podem ser definidos como qualquer fonte de carboidrato, diferente do malte de cevada, que contribua com açúcares fermentescíveis na composição do mosto (STEWART, 1994).

A utilização de adjuntos, na maioria dos casos, contribui para a redução do custo de produção de cerveja e confere suavidade ao produto final. Lewis e Young (1995) afirmam que o uso de adjuntos pode tornar a cerveja mais clara e de sabor e aroma mais delicados, haja vista que reduzem as concentrações de sólidos solúveis do malte.

Para Briggs et al. (2004) os adjuntos amiláceos podem ser separados em três classes: aqueles que podem ser misturados sem um pré-cozimento, como a farinha de trigo, aqueles que necessitam de um pré-cozimento antes do início da mosturação, como o floco de milho, e os que obrigatoriamente passam por um processo de cozimento como parte do programa de mosturação, tais como: quirera de milho, arroz e sorgo.

As fontes comerciais de amido são os grãos de cereais, que apresentam de 40 a $90 \%$ da massa seca constituída por amido (CARGILL, 2003). As cinco principais espécies consideradas mundialmente como fontes comerciais de amido são: milho, trigo, arroz, batata e mandioca. Para Cereda (1983), qualquer planta que contenha amido, teoricamente, pode ser utilizada como complemento; se for cereal, não deverá ser maltado.

De acordo com Meussdoerfer e Zarnkow (2009) o uso de matérias-primas diferentes do malte de cevada tem três razões principais que são: preço favorável, disponibilidade em regiões não apropriadas à produção de cevada e características especiais de cor e aroma em novos tipos de bebidas. Além destas características, dois outros critérios são importantes na escolha de uma fonte 
amilácea como adjunto de malte: o teor de amido e a qualidade da bebida resultante e sua aceitação pelo consumidor.

A utilização da cevada como adjunto de malte foi estudada comparando quanto ao valor energético, características físico-químicas e sensoriais, com cervejas puro malte e com cervejas produzidas com proporções diferentes de malte, cevada e maltose de milho em pó. Embora a estabilidade de espuma tenha aumentado e a quantidade de calorias da bebida resultante não tenha sido alterada em relação a uma cerveja puro malte, o rendimento da mosturação diminuiu, o que pode aumentar o custo de produção da bebida, inviabilizando sua utilização (CURI, 2006).

De acordo com Briggs et al. (2004) o trigo tem sido utilizado de várias formas, entretanto a mais usada é o trigo na forma de farinha. Atualmente algumas cervejarias inglesas utilizam entre 5 e $10 \%$ de farinha de trigo em substituição ao malte, no passado, proporções bem mais altas eram utilizadas, entre 25 e 36\%. A farinha de trigo fornece um alto conteúdo de extrato, próximo de $90,7 \%$ (base seca), e seu uso favorece a estabilidade da espuma e a baixa turvação. O adjunto é adicionado diretamente no tanque de mosturação, embora melhores extratos sejam obtidos, se a farinha for pré-umedecida ou pré-cozida.

A avaliação da utilização da fécula de batata como adjunto de malte quando comparado com o amido de milho demonstrou que o milho disponibilizou maior quantidade de açúcar solúvel para o meio comparado com a batata. Atribuiu-se essa diferença à constituição química das duas fontes de amido em termos de amilose e amilopectina. Ainda assim, a conclusão é que a fécula de batata apresenta potencial como adjunto amiláceo por ter elevado teor de amido e baixo teor de proteínas e de óleo, o que diminui o risco de turvação, melhora a estabilidade da espuma da cerveja e reduz gastos com o uso de estabilizantes (Matos et al., 2005).

Venturini Filho e Cereda (1998) produziram cervejas Pilsen em laboratório, utilizando hidrolisados de mandioca e milho como adjuntos de malte. Os hidrolisados foram obtidos a partir de fécula de mandioca e amido de milho, utilizando enzimas comerciais Termamyl ( $\alpha$-amilase bacteriana) e Fungamyl ( $\alpha$ amilase fúngica) na liquefação e sacarificação dessas matérias-primas. As cervejas foram comparadas química e sensorialmente, e não houve diferença significativa. Os autores concluíram que a fécula de mandioca apresenta potencial 
de uso como matéria prima para a produção de xarope de maltose para uso cervejeiro.

As quireras de milho e arroz são alternativas satisfatórias para as indústrias cervejeiras. Estas matérias primas necessitam passar por um processo de cozimento em altas temperaturas antes de ser misturadas ao malte durante a mosturação. Durante o cozimento devem ser incluídas enzimas como a $\alpha$-amilase bacteriana ou uma pequena quantidade de malte. Deste modo, é reduzida a viscosidade da mistura e é prevenida a retrogradação do amido (CEREDA, 1983; BRIGGS et al., 2004).

No Zimbabwe o grão de sorgo é usualmente utilizado como adjunto de malte e na forma maltada para a produção de cervejas (BVOCHORA, 2004).

Goode e Arendt (2003) elaboraram, em escala piloto, uma cerveja tipo lager utilizando $50 \%$ de sorgo não maltado e 50\% malte de cevada, e não encontraram diferença significativa em relação ao aroma entra as amostras de cerveja de sorgo, cerveja puro malte e cerveja comercial. Na análise sensorial 10 dos 23 avaliadores preferiram a cerveja de sorgo à puro malte. Concluiu-se que o sorgo pode gerar um produto com qualidade comparável a uma cerveja puro malte.

Briggs et al. (2004) esclarece que ao utilizar quirera de sorgo na produção de cerveja, foi obtido um produto de sabor desagradável, entretanto otimizações na técnica de moagem e redução na quantidade de taninos do grão, colaboraram para a obtenção de um produto a níveis aceitáveis.

Carvalho (2009) estudou a obtenção de cerveja utilizando banana como adjunto e aromatizante, obtendo uma cerveja que foi tão aceita pelo consumidor quanto as amostras de cerveja do mercado comparadas na análise sensorial.

Andrade (2007) avaliou o uso do arroz preto IAC-600 em várias concentrações como adjunto cervejeiro, e obteve um chope de propriedades sensoriais agradáveis utilizando as porcentagens malte de cevada e arroz preto em $65 \%$ e $35 \%$, respectivamente. O autor concluiu que o arroz preto apresenta grande potencial como adjunto cervejeiro, mas que outros estudos devem ser feitos de modo a aumentar a eficiência da mosturação, utilizando-se de enzimas comerciais e/ou malte com maior poder diastático. 


\subsubsection{Arroz Preto - IAC 600 (Oryza sativa) como adjunto}

O arroz é o principal componente da dieta básica da população mundial. Segundo a FAO (2004), o arroz é o responsável por $20 \%$ da fonte da energia alimentar da população mundial, enquanto o trigo equivale a $19 \%$ e o milho $5 \%$. Somente nos países asiáticos, mais de dois bilhões de habitantes têm o arroz e seus derivados como fontes de da maior parte das calorias ingeridas diariamente.

O arroz preto é bastante aromático e faz parte do cotidiano dos asiáticos desde a antiguidade, é exaltado por suas características nutricionais e, em alguns casos, medicinais (GODOY, 2005).

Pesquisas iniciadas em 1994 pelo Instituto Agronômico de Campinas (IAC) resultaram na variedade IAC-600, o primeiro cultivar de arroz preto do Brasil, para o plantio em São Paulo. Até aquele momento não existia qualquer cultivar brasileira deste tipo de arroz exótico, o que se consumia no país era importado. $\mathrm{O}$ objetivo da pesquisa foi abrir novas oportunidades para os produtores atingirem um nicho específico de mercado, com potencial de consumo interno e externo (IAC, 2004).

A variedade brasileira foi desenvolvida a partir de material selecionado da variedade Wang Xue Ren, que veio da China. O arroz preto IAC-600 tem aroma e sabor acastanhados e grãos macios, e alto teor de compostos fenólicos. Devido a esta característica acentuada, o que faz com que seu odor seja mais perceptível e sua coloração distinta, o arroz preto com qualidade recebe a denominação de arroz gourmet, e os grãos que apresentam defeitos não possuem valor de mercado (GODOY, 2005).

O interesse na associação entre o consumo de arroz pigmentado e os benefícios à saúde humana é devido ao potencial antioxidante dos compostos fenólicos que estas variedades de arroz contêm localizados na camada de aleurona, como uma mistura de antocianinas ( $\mathrm{HU}$ et al, 2003). O arroz preto apresenta dez vezes mais compostos fenólicos que o arroz branco integral (IAC, 2004).

Ruzene relatou que, no ano de 2010, foram colhidas 500 toneladas de arroz preto no Brasil, sendo que o Vale do Paraíba, no cone leste paulista, foi responsável por quase todo o cultivo realizado no país (informação pessoal) ${ }^{1}$. No campo, o arroz preto não apresenta a mesma produtividade obtida por variedades 
tradicionais, atingindo cerca de $3000 \mathrm{~kg} / \mathrm{ha}$ contra $7000 \mathrm{~kg} / \mathrm{ha}$ do arroz agulhinha, parte da baixa produtividade se deve ao acamamento, característica negativa apresentada pelo IAC-600. Ocorre ainda, durante a industrialização, a perda de aproximadamente $45 \%$, entre casca, quirera e meio arroz, diminuindo ainda mais a produtividade da variedade, o que explica o alto preço praticado para 0 consumidor final, cerca de

$R \$ 20,00 / \mathrm{kg}$. Este sub-produto do beneficiamento, caracterizado por grãos partidos e esfarelados (quirera), não tem valor de mercado e, atualmente é utilizado como ração animal.

$\mathrm{Na}$ Figura 3,0 arroz preto e sua quirera podem ser visualizados, juntamente com outros tipos de arroz.

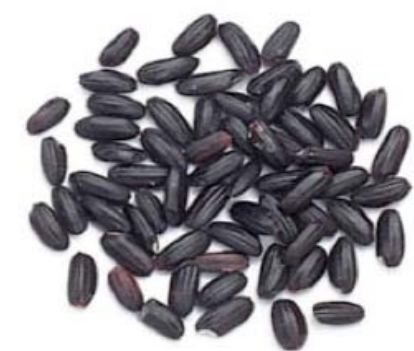

(a)
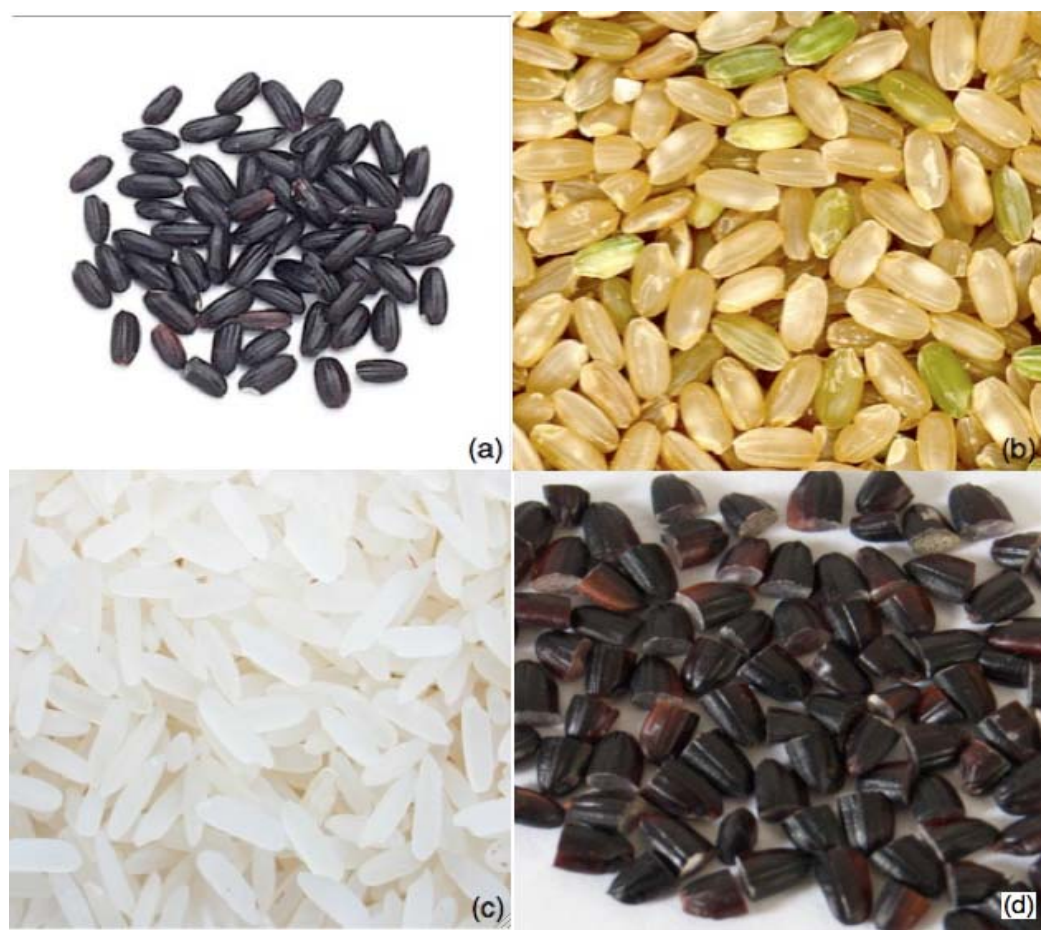

Figura 3. Arroz preto integral (a), arroz branco integral (b), arroz branco polido (c), quirera de arroz preto (d). Fontes: Foto (a) em http://www.chinese-black-rice.com/. Foto (b) em http://www.pepekitchen.com/articulo/ tipos-de-arroz-usos-culinarios/. Foto (c) adaptado de http://cozinhapequena.com/?p=1316. Foto (d): própria.

1 Informação fornecida por Francisco Ruzene. Mensagem recebida por donato@debiq.eel.usp.br em 10 fev. 2011. 
Bassinelo et al (2008b) avaliaram as características nutricionais das variedades de arroz preto IAC-600 e CNA 10887, esta oriunda da variedade indiana Heibao, e apresentaram a composição centesimal, teor de compostos fenólicos, ferro e valor calórico destas variedades em comparação com diferentes tipos de arroz. A Tabela 4 apresenta estes dados.

Tabela 4 - Composição centesimal, teor de compostos fenólicos, teor de ferro, e valor calórico de diferentes tipos de arroz (base seca). Adaptado de Bassinelo et al (2008).

\begin{tabular}{lccccc}
\hline \multicolumn{1}{c}{ PARÂMETROS } & $\begin{array}{c}\text { IAC - } \\
\mathbf{6 0 0}\end{array}$ & $\begin{array}{c}\text { CNA } \\
\mathbf{1 0 8 8 7}\end{array}$ & $\begin{array}{c}\text { ARROZ } \\
\text { INTEGRAL }\end{array}$ & $\begin{array}{c}\text { ARROZ } \\
\text { POLIDO }\end{array}$ & $\begin{array}{c}\text { ARROZ } \\
\text { BRUTO }\end{array}$ \\
\hline Ferro (mg/100g) & - & 1,39 & 1,0 & 0,7 & - \\
Cinza (\%) & 1,40 & 1,64 & $1,1-1,7$ & $0,3-0,9$ & $3,4-6,0$ \\
Gordura (\%) & 1,83 & 2,94 & $1,9-3,2$ & $0,3-0,6$ & $1,7-2,7$ \\
Proteína (\%) & 10,7 & 9,56 & $8,3-9,6$ & $7,3-8,2$ & $6,7-8,9$ \\
Fibra (\%) & 2,20 & 5,1 & $0,7-1,1$ & $0,2-0,6$ & $8,4-12,0$ \\
Carboidratos (\%) & 83,90 & 80,77 & $85-88$ & $77-89$ & $70-79$ \\
Valor calórico & 395,27 & 387,76 & 404,25 & 367,05 & - \\
(kcal) & & & & & - \\
Compostos & & & & & \\
fenólicos (mM & 906 & - & & & \\
trolox/g) & & & & & \\
\hline
\end{tabular}

A Tabela 5 apresenta a composição centesimal do arroz preto IAC-600 em comparação com arroz integral e arroz polido, segundo IAC (2011).

Tabela 5 - Composição Nutricional do Arroz preto IAC 600. Adaptado de IAC (2011)

\begin{tabular}{lccc}
\hline \multicolumn{1}{c}{ PARÂMETROS } & IAC - 600 & $\begin{array}{c}\text { ARROZ } \\
\text { INTEGRAL }\end{array}$ & $\begin{array}{c}\text { ARROZ } \\
\text { POLIDO }\end{array}$ \\
\hline Umidade \% & 8,89 & 9,77 & 9,81 \\
Cinza \% & 1,28 & 1,46 & 0,25 \\
Gordura \% & 1,67 & 2,63 & 0,38 \\
Proteína bruta \% & 9,71 & 7,04 & 6,02 \\
Fibra \% & 2,02 & 1,42 & 0,32 \\
Carboidratos \% & 80,12 & 77,68 & 79,53 \\
Valor calórico (kcal) & 359,59 & 362,55 & 360,38 \\
Compostos fenólicos ( $\mu$ M trolox/g) & 825 & 79 & - \\
\hline
\end{tabular}

Nakazawa et al (1984) estudaram o comportamento da gelificação do amido de arroz em diferentes proporções de água:arroz por Calorimetria Exploratória Diferencial (DSC), e observaram que o aumento da temperatura de conclusão $\left(T_{c}\right)$ é proporcional ao aumento da proporção de arroz. 
A temperatura de gelificação é alterada pela razão amilose/amilopectina do amido, o amido com baixo conteúdo de amilose tem menos regiões amorfas e mais cristalinas, o que aumenta a temperatura de gelificação e a entalpia endotérmica. (SASAKI et al., 2000).

O teor de amilose influencia não apenas a temperatura de gelificação, mas também fornece informações sobre as mudanças que ocorrem durante 0 processo de cocção. Arroz com alto teor de amilose, normalmente, apresenta grãos secos, soltos e com tendência à retrogradação. Os tipos com baixo teor de amilose apresentam grãos macios e pegajosos no cozimento. $\mathrm{O}$ arroz com teor intermediário apresentam grãos enxutos, soltos e macios, mesmo após o resfriamento (CASTRO; FERREIRA; MORAIS, 2003).

Heinemann et al. (2005) analisaram a composição nutricional de 3 tipos comerciais de arroz do Brasil: integral, parboilizado e polido, em relação aos teores de umidade, proteínas, gorduras e cinzas, além de teor de metais: $\mathrm{P}, \mathrm{K}$, $\mathrm{Ca}, \mathrm{Mg}, \mathrm{Mn}, \mathrm{Zn}, \mathrm{Fe}, \mathrm{Na}, \mathrm{Cu}$, Se.

\subsection{Amido}

O amido é um polissacarídeo formado apenas por unidades de $\alpha$-D-glicose, podendo ser considerado uma homoglucana (ou homopolissacarídeo). O polímero se apresenta na forma de grânulos com formato e tamanho diferentes dependendo da sua fonte botânica. É composto basicamente por duas formas de macromoléculas: amilose e amilopectina. (BILIADERIS,1991).

As moléculas de amilose e amilopectina, a estrutura do grânulo, a natureza e o teor de lipídeos presente nos grânulos variam conforme a origem do amido, isto é, são únicas para cada fonte (PÉREZ; BALDWIN; GALLANT, 2009).

A amilose é uma molécula essencialmente linear formada por unidades de D-glicose ligadas em $\alpha-(1 \rightarrow 4)$, com um pequeno numero de ramificações, cerca de uma em cada 180-320 unidades, ou 0,3 - 0,5\% (BULÉON et al.,1998). A massa molar desse polímero é variável conforme a fonte e as condições de processamento empregadas na extração do amido, podendo conter de 200 a 2000 unidades de glicose. Em uma das extremidades da cadeia polimérica a unidade terminal de glicose apresenta uma hidroxila primária e duas secundárias, assim como um grupamento aldeído redutor na forma de um hemiacetal interno, sendo denominado de final redutor da molécula (WURZBURG,1986). 
A maioria dos amidos contém aproximadamente $25 \%$ de amilose (BeMILLER; WHISTLER, 2009). A estrutura da molécula de amilose pode ser visualizada na Figura 4.

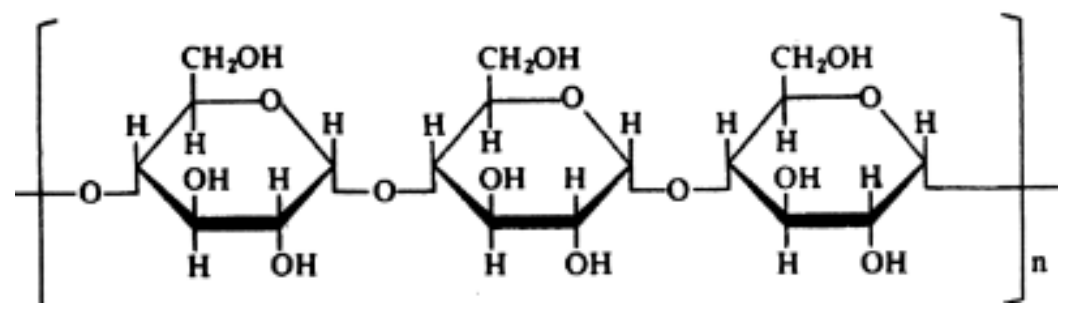

Figura 4. Estrutura de uma molécula de amilose. Adaptado de Andrade (2007).

A amilopectina é uma molécula ramificada formada por unidades D-glicose ligadas em $\alpha-(1 \rightarrow 4)$ com 5 a $6 \%$ de ligações $\alpha-(1 \rightarrow 6)$ nos pontos de ramificação (BULÉON et al.,1998). Apresentam o comprimento das ramificações variável, mais comum entre 20-30 unidades de glicose (WURZBURG,1986). Em presença de iodo a amilopectina apresenta coloração avermelhada e é estável em soluções aquosas diluídas (BILIADERIS,1991). A estrutura de uma molécula de amilopectina é apresentada na Figura 5.

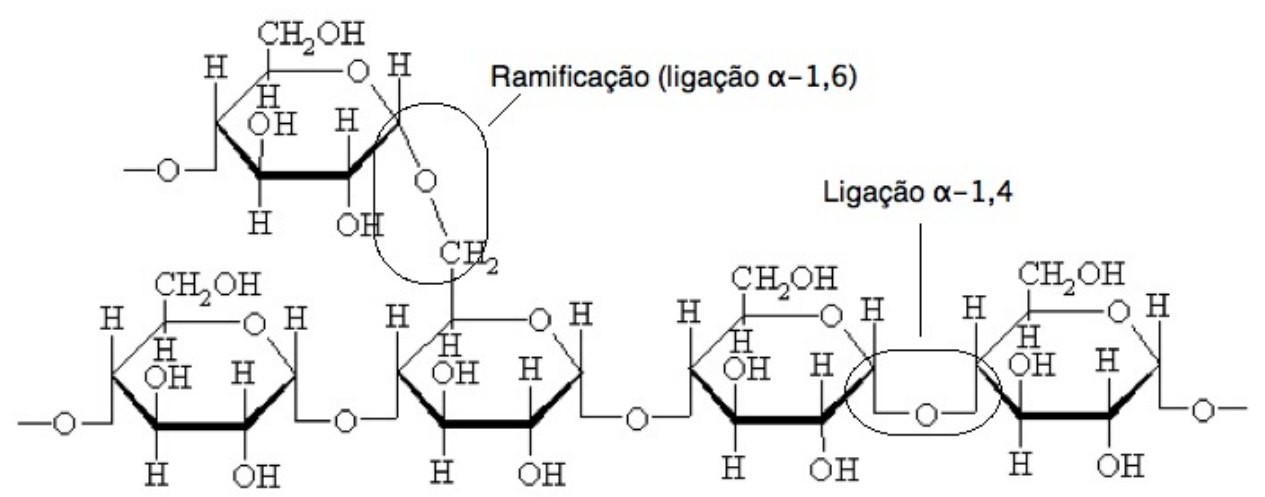

Figura 5. Estrutura de uma molécula de amilopectina. Adaptado de Andrade (2007).

O amido representa aproximadamente $85 \%$ do malte, em base seca, bem como na grande parte dos adjuntos. Os produtos de hidrólise do amido são responsáveis pela grande parte do extrato do mosto (BRIGGS et al., 2004).

Os produtos de conversão enzimática variam entre glicose e dextrinas de peso molecular elevado. Os grânulos de amido são insolúveis na água fria. A água quando penetra nas áreas amorfas do grânulo, forma ligações de hidrogênio 
com os grupos hidrófilos livres da molécula de amido. Essas ligações são fracas, mas o número de ligações é tão alto que impede sua dissolução. Quando o amido é aquecido progressivamente em presença de água, o grânulo começa a absorver esta água e inchar irreversivelmente. Este processo, associado à ruptura da estrutura granular é chamado de gelificação. A gelificação é a perda da ordem molecular no grânulo, associado a mudanças irreversíveis nas propriedades do amido, tais como, absorção de água, inchaço granular, aumento da viscosidade da mistura e solubilização do amido, entre outros. Este processo é o primeiro passo para a hidrólise, pois facilita a ação das enzimas amilolíticas. (BeMILLER; WHISTLER, 2009).

\subsection{Enzimas}

Enzimas são proteínas que catalisam reações químicas, isto é, aumentam a velocidade de reações, diminuindo sua energia de ativação. A nomenclatura de enzimas é feita de acordo com a reação catalisada. Normalmente, o sufixo "ase" é adicionado ao nome do substrato, por exemplo, amilase, pois catalisa a hidrólise do amido (OORT, 2010).

No malte, a hidrólise do amido é atribuída às atividades das $\alpha$ - e $\beta$ amilases. Enquanto estas são as principais enzimas envolvidas em temperaturas de mosturação programadas, outras enzimas atuam cumprindo funções importantes (BRIGGS, 2004). As principais enzimas atuantes, suas temperaturas e pH de atuação são mostradas na Tabela 6.

As amilases podem ser divididas em duas categorias, endo e exoamilase. As endoamilases catalisam a hidrólise das ligações glicosídicas $\alpha, 1 \rightarrow 6$ e $\alpha, 1 \rightarrow 4$ de maneira aleatória no interior da molécula de amido, formando oligossacarídeos de cadeias lineares e ramificadas de vários tamanhos. As exoamilases hidrolisam a partir da terminação não-redutora, resultando sucessivamente em produtos de cadeias pequenas. Um grande número de enzimas é conhecido por hidrolisar a molécula de amido gerando diferentes produtos e uma ação combinada de várias enzimas é necessária para a completa hidrólise do amido (AEHLE, 2007). 
Tabela 6 - Temperatura, pH e alvo de ação das enzimas (TSCHOPE, 2001)

\begin{tabular}{lccl}
\hline Enzimas & $\begin{array}{c}\text { Temperatura } \\
\text { Ótima }\left({ }^{\circ} \mathrm{C}\right)\end{array}$ & pH ótimo & \multicolumn{1}{c}{ Atuação } \\
\hline Hemicelulases & 40 a 45 & 4,5 a 4,7 & $\begin{array}{l}\text { Decomposição da hemicelulose em glucanas } \\
\text { de médio e baixo peso molecular }\end{array}$ \\
\hline Exopeptidades & 40 a 50 & 5,2 a 8,2 & $\begin{array}{l}\text { Decomposição das proteínas de alto e médio } \\
\text { peso molecular em aminoácidos }\end{array}$ \\
\hline Endopeptidases & 50 a 60 & 5,0 & $\begin{array}{l}\text { Decomposição das proteínas em produtos } \\
\text { intermediários de alto e médio peso molecular }\end{array}$ \\
\hline Dextrinase & 55 a 60 & 5,1 & $\begin{array}{l}\text { Decomposição do amido em maltose e } \\
\text { maltotriose pela hidrólise das ligações } \alpha, 1 \rightarrow 6\end{array}$ \\
\hline Beta-amilase & 60 a 65 & 5,4 a 5,6 & $\begin{array}{l}\text { Decomposição do amido em maltose pela } \\
\text { hidrólise das ligações } \alpha, 1 \rightarrow 4\end{array}$ \\
\hline Alfa-amilase & 70 a 75 & 5,6 a 5,8 & $\begin{array}{l}\text { Decomposição do amido em dextrinas } \\
\text { inferiores pela hidrólise das ligações } \alpha, 1 \rightarrow 4\end{array}$ \\
\hline
\end{tabular}

A $\alpha$-amilase é descrita como uma endoglucanase que catalisa a clivagem das ligações glicosídicas no amido e em polissacarídeos, e produzem dextrinas e oligossacarídeos. Esta enzima, usada em cervejaria, pode ser proveniente de várias fontes e apresentam estabilidade térmica em diferentes temperaturas, dependendo de sua origem (WONG; ROBERTSON, 2003). As a-amilases são estabilizadas por elevados níveis de íons cálcio, além de seus substratos, amido e dextrinas. A a-amilase é considerada uma enzima liquidificante, porque reduz a viscosidade de pastas gelificadas de amido (VAN DER MAAREL, 2010; AEHLE, 2007).

São denominadas "diástases" as enzimas provenientes do malte responsáveis pela hidrólise do amido. Destas, somente a atividade da $\beta$-amilase possui uma forte correlação com o poder diastásico, e representa $90 \%$ deste poder (BRIGGS et al, 2004; PALMER, 2006). Ela catalisa especificamente a hidrólise das ligações $\alpha-(1 \rightarrow 4)$ do amido a partir de uma extremidade redutora produzindo somente maltose, açúcar composto de duas unidades de glicose unidas por ligações $\alpha-(1 \rightarrow 4)$, com apenas uma extremidade redutora. A $\beta$-amilase é considerada uma enzima sacarificante porque produz açúcares de baixa massa molar a partir do amido (AEHLE, 2007; WONG; ROBERTSON, 2003b).

Além da maltose, a ação conjunta das $\alpha$ - e $\beta$-amilases sobre a amilopectina produz dextrinas ramificadas e lineares. A região da ramificação na amilopectina apresenta uma ligação glicosídica $\alpha-(1 \rightarrow 6)$ que é resistente ao ataque das 
amilases (MacGREGOR et al., 1999). Estas dextrinas são chamadas de dextrinas-limite e não são fermentadas pelas leveduras, o que representa uma perda de rendimento na produção de álcool (ROSS et al., 2003). A enzima dextrinase-limite hidrolisa a ligação $\alpha-(1 \rightarrow 6)$ que são os pontos de ramificação e disponibilizam dextrinas lineares para que sofram ação pela $\beta$-amilase e se converta em maltose e aumente o rendimento da mosturação (MacGREGOR et al., 1999).

Quanto maior for a proporção de adjuntos utilizados no mosto, maior a dificuldade de obter boa recuperação de extrato e maior será a viscosidade do mosto, a filtração terá seu tempo aumentado e a fermentabilidade será reduzida. Isso acontece porque em algum estágio da mosturação a quantidade de enzimas disponíveis no malte é insuficiente para hidrolisar o amido de forma adequada. Além dos problemas descritos, os níveis de nitrogênio solúvel e amino nitrogênio livre (FAN) podem diminuir até níveis que impeçam o crescimento das leveduras e a fermentação de forma satisfatória. No sistema de brassagem dupla ou duas decocções, até $60 \%$ de quirera de milho ou sorgo podem ser usados em conjunto com malte rico em enzimas e nitrogênio. Porém, mesmo neste sistema é vantajoso usar enzimas, tais como $\alpha$-amilase termoestável, para liquefazer e dextrinizar a quirera (BRIGGS et al., 2004).

Quando a quantidade de dextrinas remanescentes na cerveja é muito grande, a adição de glicoamilase ao tanque de mosturação hidrolisa a ligação glicosídica terminal $\alpha, 1 \rightarrow 6$ de oligossacarídeos, aumentando a concentração de glicose fermentescível no mosto. Porém, como a glicoamilase reage apenas com oligossacarídeos de no máximo 10 a 15 unidades de glicose, esta enzima não previne a turvação causada por moléculas de amilose e amilopectina de alta massa molar na cerveja (AEHLE, 2007).

$\mathrm{Na}$ etapa de filtração, a temperatura de $78^{\circ} \mathrm{C}$ do mosto no final da brassagem resulta em uma melhor separação do mosto da camada filtrante. Com a adição de uma $\alpha$-amilase bacteriana, a temperatura pode ser aumentada para $85^{\circ} \mathrm{C}$ na fase final da mosturação. A enzima exógena estende a degradação do amido remanescente em oligossacarídeos solúveis e continua atuando durante a filtração, assim previne o aumento na viscosidade devido à gelificação do amido. Com o aumento da temperatura do mosto no filtro, este se tornará menos viscoso 
e passará pelo meio filtrante mais rápida e suavemente, diminuindo o tempo de filtração (AEHLE, 2007; KUNZE, 1996).

As principais enzimas amilolíticas comerciais e os microrganismos produtores, os pontos de ataque durante a hidrólise e sua utilização estão apresentados na Tabela 7.

Tabela 7 - Principais enzimas amilolíticas comerciais. Adaptado de Andrade (2007)

\begin{tabular}{|c|c|c|c|c|}
\hline $\begin{array}{c}\text { Nome } \\
\text { comercial }\end{array}$ & Enzimas & $\begin{array}{c}\text { Microrganismo } \\
\text { produtor }\end{array}$ & Ataque de ligações & Utilização \\
\hline $\begin{array}{l}\text { TERMAMYL } \\
\text { 120L }\end{array}$ & $\begin{array}{l}\text { a-amilase termo } \\
\text { estável }\end{array}$ & $\begin{array}{c}\text { Bacillus } \\
\text { licheniformes }\end{array}$ & $\begin{array}{c}\alpha-(1 \rightarrow 4) \text { da amilose e da } \\
\text { amilopectina }\end{array}$ & $\begin{array}{c}\text { Liquefação do amido e } \\
\text { produção de } \\
\text { maltodextrinas }\end{array}$ \\
\hline BAN $120 \mathrm{~L}$ & $\alpha$-amilase & $\begin{array}{c}\text { Bacillus } \\
\text { amyloliquefaciens }\end{array}$ & $\begin{array}{c}\alpha-(1 \rightarrow 4) \text { da amilose e da } \\
\text { amilopectina }\end{array}$ & $\begin{array}{l}\text { Produção de } \\
\text { maltodextrinas }\end{array}$ \\
\hline AMG $300 \mathrm{~L}$ & Amiloglicosidase & Aspergillus niger & $\begin{array}{l}\alpha-(1 \rightarrow 4) \text { e } \alpha-(1 \rightarrow 6) \text { do } \\
\text { amido liquefeito }\end{array}$ & $\begin{array}{l}\text { Sacarificação do amido } \\
\text { na produção de glicose }\end{array}$ \\
\hline TERMOLASE & $\begin{array}{c}\text { a-amilase termo } \\
\text { estável }\end{array}$ & $\begin{array}{c}\text { Bacillus } \\
\text { licheniformes }\end{array}$ & $\begin{array}{c}\alpha-(1 \rightarrow 4) \text { da amilose e da } \\
\text { amilopectina }\end{array}$ & $\begin{array}{l}\text { Produção de } \\
\text { maltodextrinas }\end{array}$ \\
\hline PROLASE & $\alpha$-amilase & Não informado & Não informado & $\begin{array}{c}\text { Produção de } \\
\text { maltodextrinas }\end{array}$ \\
\hline PANZYN GA & Amiloglicosidase & Não informado & Não informado & Não informado \\
\hline $\begin{array}{l}\text { PANZYN FA } \\
100\end{array}$ & $\begin{array}{l}\text { Amilases } \\
\text { fúngicas }\end{array}$ & Não informado & Não informado & $\begin{array}{c}\text { Produção de dextrinas e } \\
\text { açúcares } \\
\text { fermentescíveis }\end{array}$ \\
\hline $\begin{array}{l}\text { OPTITHERM } \\
\text { L-340 }\end{array}$ & $\begin{array}{l}\text { a-amilase termo } \\
\text { estável }\end{array}$ & $\begin{array}{c}\text { Bacillus } \\
\text { licheniformes }\end{array}$ & $\begin{array}{c}a-(1 \rightarrow 4) \text { da amilose e da } \\
\text { amilopectina }\end{array}$ & $\begin{array}{c}\text { Liquefação do amido e } \\
\text { produção de } \\
\text { maltodextrinas }\end{array}$ \\
\hline TENASE L-680 & $\alpha$-amilase & Bacillus subtilis & $\begin{array}{c}\alpha-(1 \rightarrow 4) \text { da amilose e da } \\
\text { amilopectina }\end{array}$ & $\begin{array}{c}\text { Liquefação do amido e } \\
\text { produção de } \\
\text { maltodextrinas }\end{array}$ \\
\hline $\begin{array}{l}\text { OPTIDEX } \\
\text { L-300 }\end{array}$ & Amiloglicosidase & Aspergillus niger & $\begin{array}{c}\alpha-(1 \rightarrow 4) \text { e } \alpha-(1 \rightarrow 6) \text { do } \\
\text { amido liquefeito }\end{array}$ & $\begin{array}{l}\text { Sacarificação do amido } \\
\text { na produção de glicose }\end{array}$ \\
\hline FUNGAMYL & Sacarificantes & Aspergillus oryzae & $\begin{array}{c}\alpha-(1 \rightarrow 4) \text { da amilose e da } \\
\text { amilopectina }\end{array}$ & $\begin{array}{l}\text { Produção de maltose, } \\
\text { maltotriose e glicose }\end{array}$ \\
\hline
\end{tabular}

O efeito das condições operacionais na hidrólise do amido de arroz foi estudado por Apar e Özbek (2005), avaliando a influência do pH, temperatura, velocidade de agitação, tempo de processamento e alguns materiais, tais como hidrolisado de amido de arroz, maltose, glicose, etanol, e $\mathrm{CaCl}_{2}$ no grau de hidrólise do amido e na atividade residual da a-amilase fúngica Sigma A6211, extraída de Aspergillus oryzae, utilizando um reator descontínuo agitado. Os resultados sugerem que a velocidade de agitação acima de $200 \mathrm{rpm}$ pode comprometer a integridade da enzima devido às forças de cisalhamento geradas durante os testes, resultando numa diminuição de sua atividade, $\mathrm{o} \mathrm{pH} \mathrm{e} \mathrm{a}$ temperatura ótimos para a $\alpha$-amilase estudada foram 6,5 e $65{ }^{\circ} \mathrm{C}$, respectivamente. Os testes em relação ao tempo de processamento mostraram que melhores resultados são obtidos abaixo de 90 minutos, acima deste tempo a enzima perde a estabilidade, o que faz com que sua atividade baixe a $18,2 \%$ e 
que apenas $84,5 \%$ do amido seja hidrolisado. Com a adição de hidrolisado, maltose e glicose houve inibição no grau de hidrólise. A adição de etanol não mudou o grau de hidrólise significativamente. $\mathrm{O} \mathrm{CaCl}_{2}$ aumentou a atividade da enzima, mas não influenciou no grau de hidrólise.

Kolusheva e Marinova (2007) determinaram as condições ótimas de hidrólise do amido pela $\alpha$ - amilase (E.C. 3.2.1.1) termostável produzida por Bacillus subtilis cepa XK-86, e demonstraram que a hidrólise teve seu pico em pH 7,0, na concentração de $250 \mathrm{~g} / \mathrm{L}, 12$ unidades de enzima por $\mathrm{mL}$ de suspensão e temperatura de $90{ }^{\circ} \mathrm{C}$. Na avaliação da temperatura concluíram que o ponto ótimo seria $90{ }^{\circ} \mathrm{C}$, porque quando comparada a $100{ }^{\circ} \mathrm{C}$ a atividade foi quase idêntica e naquela temperatura não ocorreu ebulição da mistura e nem formação de espuma. Ocorreu inibição enzimática em concentrações de substrato acima de $250 \mathrm{~g} / \mathrm{L}$ e também pela glicose. A enzima estudada tem alta taxa de reação, que resulta em alta concentração de açúcares redutores em um período relativamente curto, $4 \mathrm{~h}$ e $15 \mathrm{~min}$, quando comparado à hidrólise com $\alpha$ - amilase termostável produzida por Bacillus licheniformis MB $\square 80$, que teve duração acima de 7 horas.

O efeito da proteína da farinha de arroz na hidrólise enzimática do amido de arroz foi estudado por Wansuksi et al (1999) com duas enzimas diferentes, uma a-amilase e uma glucoamilase, e mostrou que dependendo do tipo de enzima utilizada, a proteína pode contribuir positivamente com a atividade enzimática da glucoamilase e negativamente com a da $\alpha$-amilase. 


\section{MATERIAL E MÉTODOS}

Os experimentos foram realizados na Escola de Engenharia de Lorena, da Universidade de São Paulo, EEL - USP. Exceto as determinações de amido total, amilose aparente e amilopectina, realizadas no Laboratório de Análises de Alimentos da Faculdade de Ciências Farmacêuticas, da Universidade de São Paulo, FCF - USP.

\subsection{Matérias Primas}

\subsection{1. Água}

A água utilizada nos experimentos para a obtenção do mosto com arroz preto foi obtida do poço artesiano localizado no Campus I da USP - Lorena.

\subsubsection{Malte de Cevada}

O malte de cevada utilizado foi o malte claro, tipo Pilsen, gentilmente doado pela Malteria do Vale S/A, fornecido em sacos de $50 \mathrm{~kg}$.

\subsubsection{Lúpulo}

O lúpulo utilizado na pesquisa foi da variedade Zeus, na forma de pellets isomerizados, com aproximadamente $11 \%$ de iso- $\alpha$-ácidos $+\alpha$-ácidos, gentilmente doado pela Wallerstein Industrial e Comercial Ltda.

\subsubsection{Arroz Preto IAC-600}

A quirera de arroz preto IAC-600 utilizado neste trabalho foi gentilmente doada pela empresa Arroz Preto Ruzene.

\subsection{Microrganismo}

O inóculo foi preparado a partir da levedura cervejeira comercial Saccharomyces cerevisiae tipo lager Saflager S-23 (Fermentis), na forma seca, armazenada a $4{ }^{\circ} \mathrm{C}$, gentilmente doada pela empresa WE Consultoria. A variedade é originária do Instituto de Ensino e Pesquisa em Cerveja VLB, de Berlim na Alemanha, onde também é denominada de RH. 


\subsection{Caracterização do arroz preto IAC-600}

\subsubsection{Determinação da temperatura de gelificação}

A temperatura de gelificação do amido do arroz preto foi determinada por Calorimetria Exploratória Diferencial (DSC). O arroz preto foi pulverizado e misturado com água deionizada numa proporção de 1:4 (arroz: $\left.\mathrm{H}_{2} \mathrm{O}\right)$. Desta mistura, 9,1 mg foram acondicionados e selados em cadinho próprio, e analisados no aparelho de DSC TA Instruments, modelo Q10, com taxa de aquecimento de $10^{\circ} \mathrm{C} / \mathrm{min}$ e faixa de temperatura de $30^{\circ} \mathrm{C}$ a $110^{\circ} \mathrm{C}$.

\subsubsection{Determinação do teor de metais no arroz preto}

O teor de metais do arroz preto foi determinado por espectrometria de absorção atômica em espectrômetro Perkin Elmer, modelo AAnalyst 800. Os metais analisados foram: $\mathrm{Mn}, \mathrm{Cu}, \mathrm{Mg}, \mathrm{Ca}, \mathrm{K}, \mathrm{Zn}, \mathrm{Ni}, \mathrm{Pb}, \mathrm{Se}, \mathrm{Ag}, \mathrm{Al}, \mathrm{Ba}, \mathrm{Cd}, \mathrm{Co}$, Cr. Os resultados foram expressos em $\mathrm{mg} / \mathrm{g}$ e em todas as medições foi determinado o índice de recuperação do método.

\subsubsection{Determinação do teor de amido total}

O teor de amido total foi determinado enzimaticamente, utilizando o kit da marca Bioclin Diagnóstica ${ }^{\circledR}$, com o sistema glicose oxidase / peroxidase / ABTS. Este método baseia-se na quantificação do teor de glicose liberados após a reação enzimática, que, multiplicado por um fator de correção de 0,9 , resulta no teor de amido. O fator considera a remoção de uma molécula de água $(18 \mathrm{~g} / \mathrm{mol})$ das ligações covalentes entre as moléculas de glicose $(180 \mathrm{~g} / \mathrm{mol})$ que formam o amido, após a hidrólise enzimática. O amido de batata (Sigma S-2630) foi utilizado como padrão para controle da reação, sendo considerado o teor de amido total igual a $100 \%$.

\subsubsection{Determinação do teor de amilose e amilopectina}

O teor de amilose foi quantificado colorimetricamente, utilizando como padrão amilose de batata (Sigma A-0512) e amilopectina (Sigma A- 8515). O teor de amilopectina foi calculado pela diferença entre os teores de amido total e de amilose. 


\subsubsection{Determinação do teor de cinza}

A análise do teor de cinzas no arroz preto foi realizada, em duplicata, em amostra de arroz preto pulverizada e calcinada em mufla a $600{ }^{\circ} \mathrm{C}$ durante 4 horas, em cadinhos previamente pesados. Ao final da calcinação, os cadinhos foram novamente pesados e o teor de cinzas calculado segundo a equação 1 :

$$
\begin{aligned}
& \qquad \text { Teor de cinzas }(\%)=\left(\frac{m_{f}-m_{c}}{m_{a}}\right) \times 100 \\
& m_{f}=\text { massa do cadinho após calcinação } \\
& m_{c}=\text { massa do cadinho sem a amostra } \\
& m_{a}=\text { massa da amostra }
\end{aligned}
$$

\subsection{Caracterização da $\alpha$-amilase termoestável}

A $\alpha$-amilase comercial utilizada neste trabalho foi a Brautec Alfa-TF, gentilmente doada pela Prozyn BioSolutions. Trata-se de uma $\alpha$-amilase termoestável, com temperatura ótima em $95^{\circ} \mathrm{C}$ e pH ótimo entre 5,5 e 5,8.

\subsubsection{Determinação do teor de proteínas da enzima}

A determinação do teor de proteínas do extrato enzimático Brautec Alfa TF foi conduzida pelo método de Lowry (1951).

\subsubsection{Determinação da atividade enzimática}

Para a determinação da atividade da $\alpha$-amilase, $250 \mu \mathrm{L}$ de uma solução

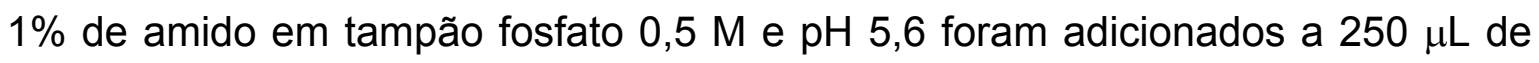
enzima diluída em 3 proporções diferentes, 1:5000; 1:10000; 1:50000 com a mesma solução tampão. Para cada diluição, foram feitas 3 replicatas com 3 repetições, totalizando 9 tubos para cada diluição. O tubos foram incubados por 60 minutos a $95^{\circ} \mathrm{C}$ em banho de água quente. O teor de açúcares redutores foi determinado pelo método do ácido 3,5-dinitrossalicílico (DNS), proposta por Miller (1959). 


\subsubsection{Determinação da atividade enzimática específica.}

Com os resultados de atividade enzimática e teor de proteínas, foi calculada a atividade específica do extrato enzimático, segundo a equação 2 :

$$
A_{\text {esp }}=\frac{A_{\text {enz }}}{T_{\text {prot }}}
$$

Na qual:

$A_{\text {esp }}=$ Atividade específica (UI/mg de proteína do extrato)

$A_{e n z}=$ Atividade enzimática $(U \mathrm{I} / \mathrm{mL}$ de extrato)

$\mathrm{T}_{\text {prot }}=$ Teor de proteínas totais no extrato enzimático (mg de proteínas $/ \mathrm{mL}$ de extrato)

\subsection{Determinação da melhor condição de hidrólise do arroz preto}

Foi realizada uma avaliação da melhor condição de hidrólise, variando a concentração da enzima em relação à massa seca de amido do arroz preto (mg de extrato/kg de amido em base seca) e o tempo de exposição do arroz à enzima.

Todos os ensaios foram conduzidos em um mosturador de bancada marca Lochner Labor + Technik, modelo LB Eletronic, com 4 cubas de mosturação com capacidade de $500 \mathrm{~mL}$. Os ensaios foram conduzidos com base nas instruções de uso da enzima recomendadas pelo fabricante.

\subsubsection{Preparo das amostras}

O arroz preto e o malte foram moídos a seco, em moinho de rolos, com distância de 0,7 mm entre os rolos, conforme Tschope (2001).

Primeiramente, foram colocados no recipiente de mosturação $33,5 \mathrm{~g}$ de arroz, adicionaram-se 167,5 g de água com pH 5,5 e uma alíquota da solução de enzima $(10 \mathrm{mg} / \mathrm{mL})$ correspondente a cada ensaio. Em todos os ensaios o arroz preto moído passou por processo de hidrólise inicialmente a $50{ }^{\circ} \mathrm{C}$ durante 10 minutos, depois a $80{ }^{\circ} \mathrm{C}$, durante 30 minutos e finalmente a $95{ }^{\circ} \mathrm{C}$, durante $\mathrm{o}$ tempo especificado para cada ensaio, conforme planejamento experimental descrito na Tabela 8. 
Tabela 8 - Matriz do planejamento fatorial completo $2^{2}$ com três ensaios no ponto central e mais quatro ensaios em estrela rotacional

\begin{tabular}{ccccc}
\hline Ensaios & $\begin{array}{c}\text { Tempo } \\
(\mathbf{m i n})\end{array}$ & $\begin{array}{c}\text { Níveis Reais } \\
\text { Concentração de Enzima } \\
(\mathbf{m g} / \mathbf{k g})\end{array}$ & $\begin{array}{c}\text { Níveis Codificados } \\
\text { Tempo }\end{array}$ & Concentração \\
\hline 1 & 40 & 400 & -1 & -1 \\
2 & 120 & 400 & +1 & -1 \\
3 & 40 & 800 & -1 & +1 \\
4 & 120 & 800 & +1 & +1 \\
5 & 80 & 600 & 0 & 0 \\
6 & 80 & 600 & 0 & 0 \\
7 & 80 & 600 & 0 & 0 \\
8 & 80 & 882 & 0 & $+1,414$ \\
9 & 80 & 317 & 0 & $-1,414$ \\
10 & 137 & 600 & $+1,414$ & 0 \\
11 & 23 & 600 & $-1,414$ & 0 \\
\hline
\end{tabular}

Após a hidrólise inicial, a temperatura do sistema foi diminuída para $47^{\circ} \mathrm{C} \mathrm{e}$ a cada recipiente foram adicionados $43,7 \mathrm{~g}$ de malte de cevada previamente moídos e 145,5 g de água com pH 5,5. Iniciou-se então o processo de mosturação em escala de bancada, de acordo com as condições mostradas na Figura 6.

Forai avaliado o teor de extrato obtido, e no analisador de bebidas Anton Paar, modelo Beer Analyzer 2.

\section{Gráfico da mosturação}

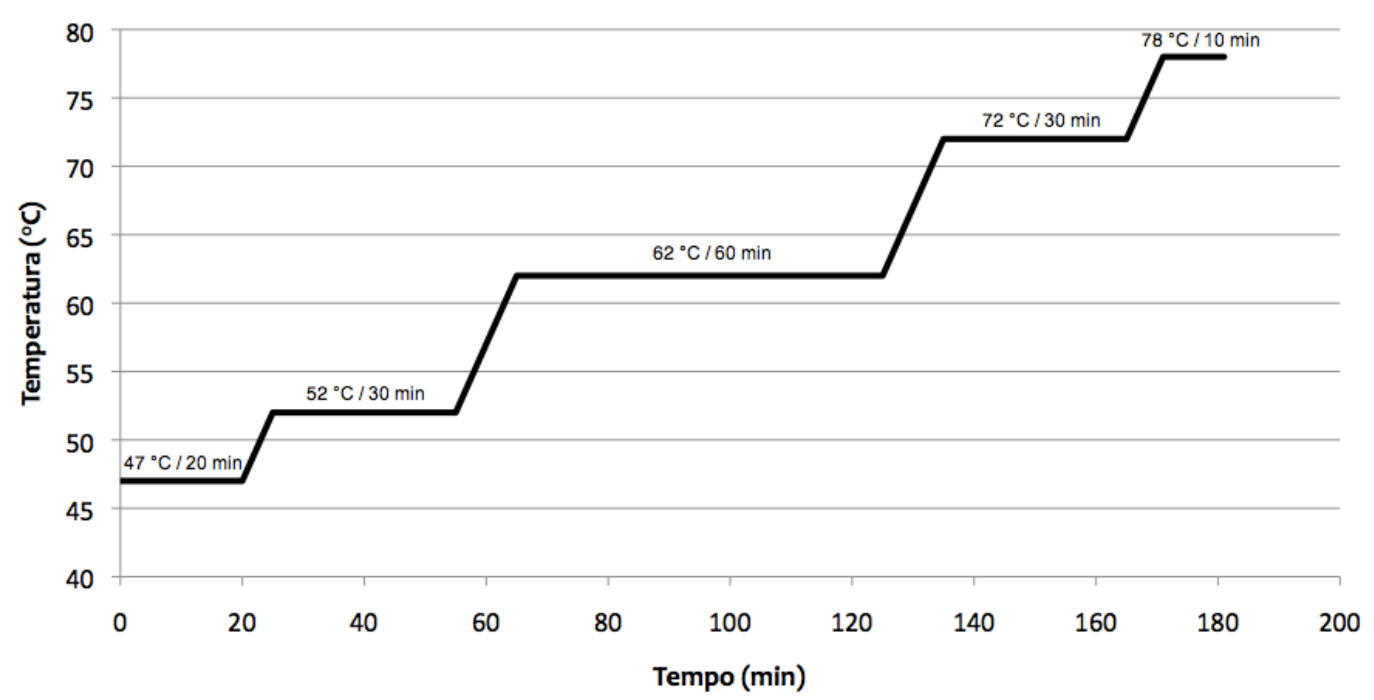

Figura 6. Gráfico da mosturação aplicada ao hidrolisado enzimático de arroz preto e malte. Adaptado de Tschope (2001). 


\subsection{Avaliação da eficiência da mosturação com arroz preto e malte e mosto puro malte.}

Com o objetivo de avaliar a eficiência da mosturação com arroz preto e malte, foram efetuados testes de mosturação em escala de bancada, utilizando o mosturador de bancada Lochner Labor + Technik, modelo LB Eletronic. Os experimentos foram conduzidos, em duplicata, sendo um mosto puro malte e um mosto com $45 \%$ de arroz preto.

A moagem dos grãos foi realizada a seco em moinho de rolo. A granulometria, tanto do malte como do arroz preto, foi ajustada, primeiramente moendo com uma distância de $1,3 \mathrm{~mm}$ entre os rolos, e posteriormente $0,7 \mathrm{~mm}$, conforme Tschope (2001).

As amostras foram preparadas utilizando a condição determinada no item 4.5, e submetidas à mosturação juntamente com o malte, de acordo com o perfil ilustrado na Figura 7. A eficiência da mosturação foi calculada pelo teor de açúcares extraídos do malte por meio do analisador de bebidas Anton Paar, modelo Beer Analyzer 2.

\subsection{Seleção da cepa de Saccharomyces cerevisiae.}

Quatro cepas de Saccharomyces cerevisiae, de baixa fermentação, foram utilizadas e foi avaliado o desempenho fermentativo no mosto com arroz preto. A cepa que apresentou o melhor desempenho foi selecionada para a produção da cerveja em escala piloto.

Os testes foram conduzidos em triplicatas, em recipientes cilíndricos de vidro, estéreis, com capacidade de $1 \mathrm{~L}$, contendo $500 \mathrm{~mL}$ de mosto padronizados a $11,6{ }^{\circ} \mathrm{P}$ e concentração inicial de $1-2 \times 10^{7}$ celulas $/ \mathrm{mL}$. Os frascos foram incubados a $20{ }^{\circ} \mathrm{C}$ por 48 horas. Foram coletadas amostras a cada 12 horas, e analisadas em relação à produção de álcool e grau de atenuação. 
Tabela 9 - Cepas de leveduras utilizadas no experimento

\begin{tabular}{cll}
\hline \multicolumn{1}{c}{ Cepa } & \multicolumn{1}{c}{ Procedência } & \multicolumn{1}{c}{ Fornecedor } \\
\hline Saflager W34/70 & Fermentis - França & $\begin{array}{l}\text { WE Consultoria } \\
\text { Assessoria e } \\
\text { Representação } \\
\text { WE Consultoria }\end{array}$ \\
Saflager S-23 & Fermentis - França & $\begin{array}{l}\text { Assessoria e } \\
\text { Representação }\end{array}$ \\
& Academia Doemens - & Senai - Vassouras \\
Fermento 308 & Alemanha & Instituto de Investigación \\
& Instituto de Investigación & Alimentícia de Cuba
\end{tabular}

\subsection{Fermentação em escala piloto}

Os ensaios em escala piloto foram conduzidos na microcervejaria da Planta Piloto de Bebidas da EEL, com capacidade de produção de 200 L. Foram preparados 3 lotes de $130 \mathrm{~L}$ de cerveja com $45 \%$ arroz preto em relação ao extrato primitivo.

\subsubsection{Preparo do inóculo}

Foi pesado $1 \mathrm{~g}$ da levedura seca, em seguida reidratada com $10 \mathrm{~mL}$ de água destilada estéril. Após 10 minutos, este volume foi transferido para um Erlenmeyer de $500 \mathrm{~mL}$ contendo $200 \mathrm{~mL}$ de mosto com arroz preto a 5 'Plato. $\mathrm{O}$ frasco foi incubado a $30^{\circ} \mathrm{C}$, em incubadora com agitação orbital, a $150 \mathrm{rpm}$ por 18 horas. Posteriormente, o inóculo obtido foi avolumado para $2 \mathrm{~L} \mathrm{com} \mathrm{a} \mathrm{adição} \mathrm{de}$ 1,8 L de mosto com arroz preto a $7^{\circ} \mathrm{P}$, em condições assépticas, em um frasco Erlenmeyer com capacidade para $4 \mathrm{~L}$, e incubado a $30{ }^{\circ} \mathrm{C}$, em incubadora com agitação orbital, a 120 rpm por 18 horas.

Após este tempo, o inóculo foi avolumado para $12 \mathrm{~L}$ pela adição de $10 \mathrm{~L}$ de mosto com arroz preto a $10{ }^{\circ} \mathrm{P}$ diretamente no tanque de fermentação, com capacidade para $200 \mathrm{~L}$. A mistura foi, então, incubada a $15^{\circ} \mathrm{C}$ e as células submetidas a aeração pelo tempo necessário para atingir uma concentração celular de 1 a $2 \times 10^{8}$ células $/ \mathrm{mL}$, de modo que ao adicionar o mosto, a 
concentração celular fosse de aproximadamente de $10^{7}$ células $/ \mathrm{mL}$ no início da fermentação.

\subsubsection{Preparo do Mosto}

A quantidade de malte e adjuntos foi calculada para a fabricação de $130 \mathrm{~L}$ de mosto a $12{ }^{\circ} \mathrm{P}$, levando em consideração o rendimento de $75 \%$ da massa de malte e $80 \%$ da massa do arroz em açúcares fermentáveis.

Foram pesados 9,6 $\mathrm{kg}$ de arroz preto e $12,5 \mathrm{~kg}$ de malte de cevada, e em seguida moídos em moinho de rolos, com distância de 0,7 mm entre os rolos.

No tanque de mosturação foram adicionados o arroz, 48 litros de água e 2,24 g de extrato enzimático Brautec Alfa - TF. O pH foi ajustado em 5,5 com ácido lático $85 \%$. Esta mistura foi hidrolisada como descrito no 4.5.1. Ao final deste processo, foram adicionados o malte, 52 litros de água e 15,75 g de cloreto de cálcio. Toda o sistema foi submetido à mosturação, conforme descrito no item 4.5.1. Ao final da mosturação a $72{ }^{\circ} \mathrm{C}$ foi realizado o teste com solução de iodo a $0,2 \mathrm{~N}$ para verificar a sacarificação do amido do malte e das dextrinas resultantes da hidrólise prévia do arroz. Após a confirmação, a mistura foi aquecida a $78{ }^{\circ} \mathrm{C}$ durante 10 minutos para inativar as enzimas do malte.

\subsubsection{Filtração do Mosto}

O mosto preparado com arroz preto foi submetido à filtração em tanque de açi inox com capacidade para $120 \mathrm{~L}$ contendo agitador, disco filtrante ranhurado Pak Screens, bomba centrífuga e isolamento térmico. A camada filtrante, denominada "torta", formada pelo bagaço do malte e do arroz, foi lavada com $50 \mathrm{~L}$ $(30+20)$ de água a $78^{\circ} \mathrm{C}$.

\subsubsection{Filtração e Fervura do Mosto}

Quando o permeado que estava saindo do filtro apresentou concentração de açúcares de $3,5^{\circ}$ Brix, a filtração foi interrompida e o mosto doce foi submetido à fervura em tanque de fervura encamisado, com capacidade para $250 \mathrm{~L}$, provido de aquecimento elétrico e isolamento térmico, até que fosse corrigida a concentração de açúcares no mosto em $12{ }^{\circ} \mathrm{P}$. Durante a fervura foram 
adicionados $65 \mathrm{~g}$ de lúpulo em pellets, $30 \mathrm{~g}$ no início da fervura e $35 \mathrm{~g} 15$ minutos antes do final.

Após a fervura, o mosto foi submetido à recirculação tangencial por cerca de 60 minutos para permitir a precipitação de proteínas e polifenóis. Durante este tempo, o mosto foi resfriado por meio da troca da água da camisa por água fria corrente.

Após a recirculação, o mosto foi mantido em repouso por 60 minutos, sendo resfriado até $30{ }^{\circ} \mathrm{C}$. Ao final deste período, foi retirado o sedimento de proteínas e polifenóis, denominado "trub", e o mosto transferido por bombeamento para o tanque de fermentação.

\subsubsection{Fermentação}

As fermentações foram conduzidas em tanque de fermentação de $200 \mathrm{~L}$, equipado com controlador e indicador digital de temperatura e registro para retirada de amostra.

Após a transferência do mosto para o fermentador, iniciou-se a aeração por 20 minutos com ar estéril. Após este tempo, foi adicionado o inóculo e a temperatura regulada em $15{ }^{\circ} \mathrm{C}$. Foram retiradas amostras a cada 12 horas e feitas determinações dos teores de álcool e de extratos por meio do analisador de bebidas Anton Paar, modelo Beer Analyzer 2. O ponto final da fermentação foi determinado quando estes teores não se alterassem entre 2 medições.

Imediatamente ao constatar o término da fermentação, o excesso de leveduras foi retirado pelo fundo do fermentador e a temperatura ajustada em 0 ${ }^{\circ} \mathrm{C}$ para o início da maturação, permanecendo assim por 14 dias.

\subsubsection{Filtração}

Ao término da maturação, o chope obtido foi filtrado em filtro de placas de celulose KS-100, utilizando terra diatomácea como adjuvante de filtração, sob pressão de $2 \mathrm{kgf} / \mathrm{cm}^{2}$. O chope filtrado foi armazenado no tanque de fermentação para correção do teor de $\mathrm{CO}_{2}$ para $2 \mathrm{kgf} / \mathrm{cm}^{2}$ e posterior análise sensorial. 


\subsubsection{Embalagem e Pasteurização}

Após a filtração e correção do teor de $\mathrm{CO}_{2}$, uma parte do chope foi envasado manualmente em 24 garrafas de cerveja de $600 \mathrm{~mL}$ desinfetadas e limpas.

O processo de pasteurização foi conduzido em autoclave com água suficiente para cobrir as garrafas dispostas em pé, deixando de fora apenas a boca da garrafa. O controle de temperatura foi feito com um termômetro digital colocado em uma garrafa com água, destampada. Após a temperatura atingir 63 ${ }^{\circ} \mathrm{C}$ dentro da garrafa controle, iniciou-se o tempo de contagem da pasteurização, estipulados em 30 minutos.

Após este tempo, as garrafas foram submersas em água a $2{ }^{\circ} \mathrm{C}$, e $\mathrm{o}$ controle de temperatura feito com a adição de gelo para manter a temperatura baixa. O recipiente com todas as garrafas foi armazenado em câmara fria a $2{ }^{\circ} \mathrm{C}$ até o momento da análise sensorial.

\subsection{Acompanhamento analítico da fermentação}

\subsubsection{Análises Físico-Químicas}

No mosto foram determinados o teor de extrato aparente e extrato real, por meio do analisador de bebidas Anton Paar, modelo Beer Analyzer 2. O mosto também foi analisado por Cromatografia Líquida de Alta Eficiência (CLAE) para a identificação do teor de cada tipo de açúcar. No produto acabado, foram analisados o teor de álcool e açúcares (Beer Analyzer 2).

A massa de extrato recuperado foi calculada usando a equação 3 :

$$
\operatorname{Massa}_{E R}=\frac{\text { Teor }_{\text {AC }} \times V_{\text {MOSTO }}}{100}
$$

Na qual:

Massa $_{E R}=$ Massa de extrato recuperado no mosto misto (g);

Teor $_{A C}=$ Teor de açúcar no extrato $(\% \mathrm{~m} / \mathrm{v})$;

$V_{\text {mosto }}=$ Volume do mosto $(\mathrm{L})$. 
A eficiência da mosturação foi calculada pela equação 4 :

$$
E m=\frac{\text { Massa }_{E R}}{M_{\text {malte }}+M_{\text {adjunto }}} \times 100
$$

Na qual:

$E_{m}=$ Eficiência da mosturação (\%);

$M_{E R}=$ massa de extrato recuperado no mosto $(\mathrm{g})$;

$M_{\text {malte }}=$ massa de extrato do malte $(\mathrm{g})$;

$M_{\text {adjunto }}=$ massa de extrato do adjunto (g).

\subsubsection{Análise da fermentação}

Durante a fermentação foram medidos o teor de álcool (\% v/v), o extrato real $(\% \mathrm{~m} / \mathrm{m})$, e o extrato aparente ( $\left.{ }^{\circ} \mathrm{P}\right)$, grau aparente de fermentação (\%) e grau real de fermentação (\%), por meio do equipamento Beer Analyzer 2 (Anton Paar).

Ao final da fermentação, o rendimento foi calculado pela equação 5 .

$$
Y_{p / s}=\frac{m_{E t}}{m_{A c}}
$$

Na qual:

$\mathrm{Y}_{\mathrm{p} / \mathrm{s}}=$ Rendimento do álcool produzido em relação ao açúcar consumido $(\mathrm{g} / \mathrm{g})$;

$\mathrm{m}_{\mathrm{Et}}=$ massa de etanol produzido $(\mathrm{g})$;

$\mathrm{m}_{\mathrm{Ac}}=$ massa de açúcar consumido $(\mathrm{g})$

A eficiência da fermentação foi obtida por meio da equação (6):

$$
\text { Eficiência }(\%)=\frac{Y_{p / s \text { obtido }}}{Y_{p / s \text { teórico }}} \times 100
$$

O cálculo da produtividade em álcool é feito através da seguinte equação 7 : 


$$
\mathrm{Q}=\frac{T A_{f}-T A_{i}}{t}
$$

$\mathrm{Q}=$ Produtividade em álcool $\left(\mathrm{g} \cdot \mathrm{L}^{-1} \cdot \mathrm{h}^{-1}\right)$

$\mathrm{TA}_{\mathrm{f}}=$ Teor de álcool final $(\mathrm{g} / \mathrm{L})$

$\mathrm{TA}_{\mathrm{i}}=$ Teor de álcool inicial $(\mathrm{g} / \mathrm{L})$

$t=$ tempo $(h)$

\subsubsection{Análise microbiológica}

No início e a cada 12 horas, foram realizadas contagens de leveduras suspensas por contagem na câmara de Neubauer $(11400 \mathrm{~mm} 2 \times 1110 \mathrm{~mm}) \mathrm{e}$ expresso em cel/mL. A determinação da viabilidade celular (células viáveis e não viáveis) foi realizada pelo método com azul de metileno, segundo ASBC (1996).

\subsection{Análise sensorial}

Foram aplicados testes de Análise Sensorial, em sala apropriada, da Planta Piloto de Bebidas da EEL, equipado com cabines individuais, iluminação adequada.

O painel de provadores não treinados foi composto por 63 consumidores de ambos os sexos. Foram aplicados o Teste de Comparação Pareada ou Preferência e o Teste de Aceitação, com escala hedônica de 9 pontos. O formulário utilizado na análise sensorial está ilustrado na Figura 8. As amostras utilizadas durante o teste foram a cerveja de arroz preto pasteurizada e não pasteurizada (chope). Aproximadamente $100 \mathrm{~mL}$ de amostra foram servidas individualmente na temperatura de consumo, entre 2 e $5^{\circ} \mathrm{C}$, em copos plásticos transparentes, e entre as amostras um copo com água mineral e biscoito cream cracker para enxágue e renovação do paladar. 


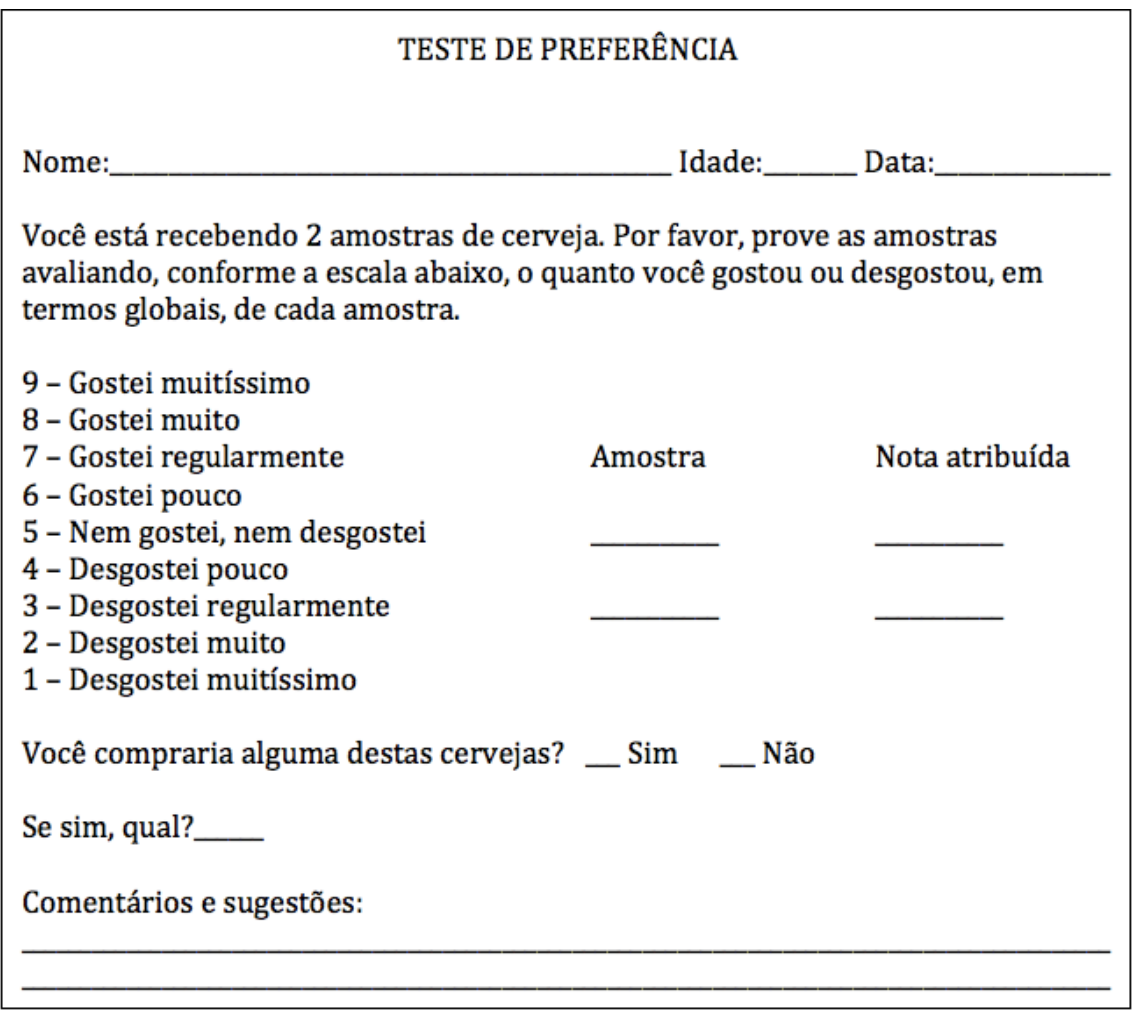

Figura 7. Formulário utilizado no Teste de Comparação Pareada e Teste de Aceitação

\subsection{Análise estatística}

Os experimentos foram internamente casualizados, e realizados em duplicata. Para todas as análises foram calculados média e desvio padrão. Para a análise sensorial a significância estatística foi obtida a partir de tabela específica para este método, conforme ASBC (1996). Para o teste de aceitação, bem como para os resultados de rendimentos de mosturação e fermentação e das análises físico-químicas e microbiológicas dos mostos foram calculadas médias e desvio padrão, e aplicado teste $t$ de Student em nível de $5 \%$ de probabilidade. 


\section{RESULTADOS E DISCUSSÃO}

\subsection{Caracterização da $\alpha$-amilase termoestável Prozyn Brautec Alfa-TF ${ }^{\circledR}$}

\subsubsection{Determinação do teor de proteínas}

O teor de proteínas obtido no extrato enzimático pelo método proposto por Lowry et al. (1951) foi de 20,5 $\pm 1,24 \mathrm{mg}$ de proteína/mL de extrato.

\subsubsection{Determinação da atividade enzimática}

A atividade enzimática da enzima Brautec Alfa TF foi determinada pela medida dos açúcares redutores resultantes da hidrólise, por meio do método do ácido 3,5-dinitrossalicílico (3,5-DNS) (Miller, 1959). Os resultados obtidos estão apresentados na Tabela 10. As fichas de informação da Termamyl 2X e Termamyl 120L, fornecidas pela Novozymes e da Brautec Alfa-TF, fornecida pela Prozyn, apresentam valores superiores aos resultadosobtidos experimentalmente. A atividade enzimática declarada pela Prozyn é visivelmente diferente da determinada de forma experimental, o que confirma a necessidade de testar o reagente antes do experimento. Esta diferença pode ter ocorrido pela degradação das moléculas de $\alpha$-amilase devido ao tempo de armazenamento, ou porque, durante os testes, não foi utilizado $\mathrm{Ca}^{+2}$, o que pode ter desestabilizado a molécula da enzima e diminuído sua atividade (TANAKA; HOSHINO, 2003).

Tabela 10. Comparação entre as atividades declaradas e a atividade medida experimentalmente.

\begin{tabular}{ccc}
\hline Enzima & Atividade $(\mathrm{Ul} / \mathrm{mL})$ & $\%$ de atividade $^{\times \times}$ \\
\hline Brautec Alfa TF* & 163830 & $100,0 \%$ \\
Brautec Alfa TF** & $112000^{\times}$ & $68,4 \%$ \\
Termamyl 2X*** & 147280 & $89,9 \%$ \\
Termamyl 120 L*** & 73640 & $44,9 \%$ \\
\hline $\begin{array}{c}\times \text { Média de três replicatas } \\
\text { * Em relação à maior atividade declarada } \\
* \text { Dados declarados pela Prozyn } \\
* * \text { Dados Experimentais } \\
* * \text { Dados declarados pela Novozymes }\end{array}$ &
\end{tabular}


A atividade específica da Brautec Alfa-TF obtida foi de $5463 \mathrm{Ul} / \mathrm{mg}$ de proteína do extrato, atividade consideravelmente maior que do extrato estudado por Haq et al. (2010), que apresentou atividade de 756,83 U/mg.

\subsection{Caracterização do Arroz Preto IAC-600 (Oryza sativa)}

\subsubsection{Temperatura de Gelificação do Arroz Preto}

Foi determinada a temperatura de gelificação do arroz preto pela análise por Calorimetria Exploratória Diferencial (DSC), e a temperatura de conclusão da curva endotérmica $\left(T_{c}\right)$ encontrada foi de $78,68{ }^{\circ} \mathrm{C}$. Este resultado é similar àqueles apresentados por Shu et al. (2006) em 8 amostras de arroz de diferentes variedades analisadas e na variedade analisada por Bassinelo et al. (2008b), conforme podem ser vistos na Tabela 11.

Usansa (2008) determinou a faixa de temperatura de gelificação do amido do malte de duas variedades de arroz preto tailandês e estes apresentaram temperaturas entre 70 e $74^{\circ} \mathrm{C}$.

Como a temperatura ótima da Brautec Alfa-TF é de $95{ }^{\circ} \mathrm{C}$, a enzima se mostra adequada ao processo de hidrólise proposto, já que aos $78,7^{\circ} \mathrm{C}$ os grãos de amido do arroz preto estarão completamente gelificados quando a enzima estiver no seu ponto ótimo de atuação.

Tabela 11 - Tabela comparativa de temperaturas finais de gelificação do amido em 10 variedades de arroz.

\begin{tabular}{lc}
\hline \multicolumn{1}{c}{ Variedade } & $\begin{array}{c}\text { Temperatura final de gelificação } \\
\left(\mathrm{T}_{c}\right)\left({ }^{\circ} \mathrm{C}\right)\end{array}$ \\
\hline Arroz Preto IAC 600 & 78,7 \\
${ }^{* *}$ Arroz Preto CNA 10887 & 68,0 \\
* Huangyu A 110 & 76,7 \\
* Huangyu B & 77,8 \\
* II32 B & 82,5 \\
* R3027 & 80,8 \\
* Niqingzhan & 76,5 \\
* Xiushui & 72,7 \\
* (II23A/Huangyu B) F1 & 78,8 \\
* (Huangyu A/II32 B) F1 & 78,7 \\
* dados em Shu et al. (2006) & \\
${ }^{* *}=$ dados em Bassinelo et al. (2008b) &
\end{tabular}




\subsubsection{Quantificação de Metais}

Foram realizados testes para quantificar o teor de metais presentes nesta variedade de arroz preto, cujos resultados se encontram apresentados na Tabela 12.

Tabela 12 - Teores de metais na amostra de quirera de arroz preto.

\begin{tabular}{ccc|ccc}
\hline Metal & $\begin{array}{c}\text { Teor } \\
(\mathrm{mg} / \mathrm{g})\end{array}$ & $\begin{array}{c}\text { Recuperação } \\
(\%)\end{array}$ & Metal & $\begin{array}{c}\text { Teor } \\
(\mathrm{mg} / \mathrm{g})\end{array}$ & $\begin{array}{c}\text { Recuperação } \\
(\%)\end{array}$ \\
\hline $\mathrm{K}$ & 2,410 & 102,8 & $\mathrm{Al}$ & $<0,010$ & 95,7 \\
$\mathrm{Mg}$ & 0,960 & 98,7 & $\mathrm{Co}$ & $<0,010$ & 98,8 \\
$\mathrm{Zn}$ & 0,030 & 92,2 & $\mathrm{Cr}$ & $<0,010$ & 99,1 \\
$\mathrm{Mn}$ & 0,020 & 94,4 & $\mathrm{Cd}$ & $<0,005$ & 93,3 \\
$\mathrm{Ca}$ & 0,020 & 96,7 & $\mathrm{Cu}$ & $<0,005$ & 93,0 \\
$\mathrm{Se}$ & $<0,500$ & 93,6 & $\mathrm{~Pb}$ & $<0,005$ & 92,1 \\
$\mathrm{Ba}$ & $<0,020$ & 93,7 & $\mathrm{Fe}$ & n.d. & 101,9 \\
$\mathrm{Ni}$ & $<0,010$ & 96,0 & $\mathrm{Na}$ & n.d. & 103,0 \\
$\mathrm{Ag}$ & $<0,010$ & 97,2 & & & \\
\hline
\end{tabular}

n.d. = não detectado

$\mathrm{Na}$ Figura 8 observa-se que os teores de metais diferem dos valores encontrados no arroz branco por Heinemann (2005), na forma integral e parboilizado integral. Nota-se também que para o arroze integral e integral parboilizado, o potássio é o mineral mais abundante no arroz preto com 2,41 $\mathrm{mg} / \mathrm{g}$, teor $32,6 \%$ maior do que na versão integral $(1,82 \mathrm{mg} / \mathrm{g})$ e $57,6 \%$ maior que na forma integral parboilizada $(1,53 \mathrm{mg} / \mathrm{g})$.

$\mathrm{O}$ arroz preto tem mais minerais que as versões do arroz branco, como pode ser visto na Figura 8. 


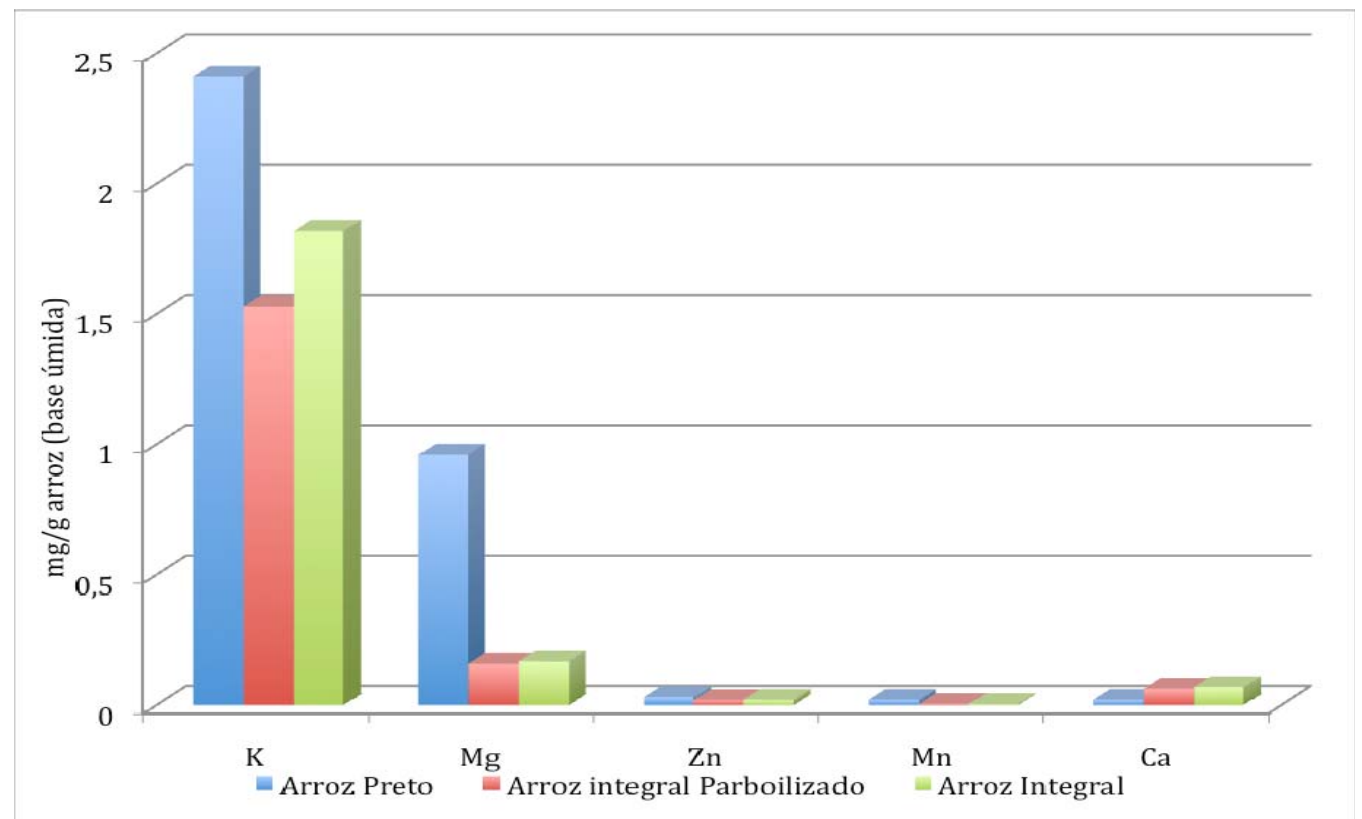

Figura 8. Gráfico comparativo do teor de alguns metais entre tipos diferentes de arroz.

\subsubsection{Teores de Amido Total e Amilose Aparente}

Os resultados são apresentados na Tabela 13 referem-se à determinação de teores de amido total e amilose aparente

Tabela 13. Teores de amido total e amilose aparente em quirera de arroz preto IAC-600

\begin{tabular}{lcccc}
\hline & $\begin{array}{c}\text { Teor de Amido } \\
\text { Total }(\%) \pm \text { Desvio } \\
\text { padrão }\end{array}$ & $\begin{array}{c}\text { Coeficiente de } \\
\text { Variação }\end{array}$ & $\begin{array}{c}\text { Teor de Amilose } \\
(\%) \pm \text { Desvio } \\
\text { padrão }\end{array}$ & $\begin{array}{c}\text { Coeficiente } \\
\text { de Variação }\end{array}$ \\
\hline Base úmida & $73,67 \pm 1,25$ & 1,70 & $9,95 \pm 0,30$ & 2,97 \\
Base seca & $83,20 \pm 1,41$ & 1,70 & $11,23 \pm 0,33$ & 2,97 \\
\hline
\end{tabular}

Uma composição centesimal média do arroz integral, com o teor de amido de $74,12 \%$ em base seca, foi determinada por Walter et al. (2008). Embora a variedade IAC-600 seja integral, o teor de amido total obtido é similar ao do arroz branco polido e do arroz parboilizado polido, $87,58 \%$ e $85,08 \%$ em base seca, respectivamente.

Bassinelo et al. (2008) citaram que a linhagem de arroz preto CNA 10887 apresenta cerca de $17 \%$ de amilose, em base seca, valor considerado baixo pela autora. O teor de amilose encontrado no arroz preto IAC-600 é consideravelmente menor do que aquele presente no CNA 10887. Isto explica a característica pegajosa da variedade após o cozimento, pois segundo Castro et al. (2003), as 
cultivares com baixo teor de amilose aparente apresentam grão macios, aquosos e pegajosos após o cozimento, características muito marcantes no IAC-600.

\subsubsection{Teor de Cinzas}

O teor de cinzas foi determinado, em mufla a $600{ }^{\circ} \mathrm{C}$ durante 4 horas, e o valor obtido foi de 1,61 $\pm 0,02 \%$. Este resultado é superior àquele encontado no arroz preto IAC-600 por Bassinelo et al. (2008), que foi de 1,40\%. Porém, isto pode ocorrer devido ao fato do arroz ser uma matéria-prima de origem vegetal, o que faz com que hajam variações significativas nos teores de cinza. Em relação aos outros tipos de arroz integral, o IAC-600 apresentou uma quantidade maior de cinzas do que o arroz integral analisado por Heinemann et al. (2005), 1,21 \pm $0,06 \%$ e também do valor encontrado por Walter et al (2008), que foi de $1,15 \%$.

\subsection{Determinação da melhor condição de hidrólise enzimática do arroz preto}

Os resultados dos experimentos realizados para determinar a melhor condição de hidrólise estão apresentados na Tabela 14.

Os resultados foram submetidos a análise estatística por meio do programa Design Expert v. 6.0 e foi aplicado o método da superfície de resposta, que não apresentou curvatura, ou seja, nenhum dos resultados apresentou diferença estatística entre si. Em virtude disto, foi adotada a condição de menor tempo e menor concentração de enzima para os estudos posteriores (23 minutos na temperatura ótima e $317 \mathrm{mg}$ de extrato/kg de amido em base seca). Foram feitas, ainda, 6 repetições desta condição para confirmar o resultado obtido no experimento. Os resultados, a média e o desvio padrão são apresentados na Tabela 14. 
Tabela 14. Valores de extrato e eficiência de fermentação obtidos em diferentes condições de hidrólise.

\begin{tabular}{ccccccc}
\hline \multirow{2}{*}{ Condição } & \multicolumn{2}{c}{ Níveis Reais } & \multicolumn{2}{c}{ Níveis Codificados } & Extrato & Eficiência \\
\cline { 2 - 4 } & $\begin{array}{c}\text { Tempo } \\
(\mathrm{min})\end{array}$ & Enzima $(\mathrm{mg} / \mathrm{kg})$ & Tempo & Enzima & & \\
\hline 1 & 40 & 400 & -1 & -1 & 15,12 & 72,63 \\
2 & 120 & 400 & +1 & -1 & 14,39 & 68,91 \\
3 & 40 & 800 & -1 & +1 & 14,90 & 71,54 \\
4 & 120 & 800 & +1 & +1 & 15,07 & 72,41 \\
5 & 80 & 600 & 0 & 0 & 15,72 & 75,71 \\
6 & 80 & 600 & 0 & 0 & 14,98 & 71,95 \\
7 & 80 & 600 & 0 & 0 & 14,73 & 70,63 \\
8 & 80 & 882 & 0 & $+1,414$ & 15,06 & 72,31 \\
9 & 80 & 317 & 0 & $-1,414$ & 15,45 & 74,31 \\
10 & 137 & 600 & $+1,414$ & 0 & 15,31 & 73,62 \\
11 & 23 & 600 & $-1,414$ & 0 & 15,42 & 74,17 \\
\hline
\end{tabular}

Tabela 15. Repetições da condição escolhida para a hidrólise da quirera de arroz

\begin{tabular}{ccccccc}
\hline \multirow{2}{*}{ Condição } & \multicolumn{2}{c}{ Níveis Reais } & \multicolumn{2}{c}{ Níveis Codificados } & \multirow{2}{*}{$\begin{array}{c}\text { Extrato } \\
\left.\text { Obtido ( }{ }^{\circ} \mathrm{P}\right)\end{array}$} & Eficiência (\%) \\
\cline { 2 - 6 } & $\begin{array}{c}\text { Tempo } \\
(\mathrm{min})\end{array}$ & Enzima (mg/kg) & Tempo & Enzima & & \\
\hline 12 & 23 & 317 & $-1,414$ & $-1,414$ & 15,06 & 72,31 \\
13 & 23 & 317 & $-1,414$ & $-1,414$ & 15,40 & 74,08 \\
14 & 23 & 317 & $-1,414$ & $-1,414$ & 15,51 & 74,62 \\
15 & 23 & 317 & $-1,414$ & $-1,414$ & 14,83 & 71,18 \\
16 & 23 & 317 & $-1,414$ & $-1,414$ & 14,79 & 70,95 \\
17 & 23 & 317 & $-1,414$ & $-1,414$ & 15,13 & 72,67 \\
\hline
\end{tabular}

\subsection{Escolha da cepa de Saccharomyces cerevisiae}

O experimento de seleção de cepa foi conduzido em triplicata, durante 48 horas. A média das diferentes análises obtidas estão apresentados na Tabela 18. O perfil de consumo de açúcares e da produção de álcool estão ilustrados nas Figuras 8 e 9, respectivamente. Dentre as variedades estudadas, a cepa S-23 (Fermentis) apresentou a maior produtividade em álcool e, apesar de não apresentar diferença estatística no desempenho fermentativo da cepa Saflager W $34 / 70$, por este motivo, a cepa foi utilizada na fermentação dos lotes em escala piloto. 
Tabela 16. Parâmetros fermentativos após 48 horas de fermentação

\begin{tabular}{lcccrr}
\hline \multicolumn{1}{c}{ Parâmetro } & $\begin{array}{c}\text { Teste de } \\
\text { Atenuação }\end{array}$ & \multirow{2}{*}{$\mathbf{3 0 8}$} & IIAC & \multicolumn{1}{c}{$\begin{array}{c}\text { Saflager } \\
\text { S-23 }\end{array}$} & $\begin{array}{c}\text { Saflager } \\
\text { W34/70 }\end{array}$ \\
\hline Álcool $(\% \mathrm{v} / \mathrm{v})$ & 4,89 & $3,47 \pm 0,27$ & $4,20 \pm 0,09$ & $5,01 \pm 0,04$ & $4,88 \pm 0,06$ \\
Extrato Real $(\% \mathrm{~m} / \mathrm{m})$ & 3,58 & $6,00 \pm 0,40$ & $4,75 \pm 0,16$ & $3,84 \pm 0,17$ & $4,03 \pm 0,27$ \\
Extrato Original ( $\left.{ }^{\circ} \mathrm{P}\right)$ & 11,06 & $11,25 \pm 0,02$ & $11,15 \pm 0,06$ & $11,48 \pm 0,20$ & $11,66 \pm 0,14$ \\
Extrato Aparente ( $\left.{ }^{\circ} \mathrm{P}\right)$ & 1,82 & $4,77 \pm 0,50$ & $3,25 \pm 0,20$ & $2,04 \pm 0,16$ & $2,48 \pm 0,07$ \\
Grau Real de Ferm (\%) & 68,94 & $48,10 \pm 3,63$ & $58,73 \pm 1,21$ & $67,99 \pm 0,94$ & $65,17 \pm 0,39$ \\
Grau Apar de Ferm (\%) & 83,57 & $57,53 \pm 4,49$ & $70,86 \pm 1,70$ & $82,22 \pm 1,11$ & $78,73 \pm 0,49$ \\
$\mathrm{Y}_{\mathrm{p} / \mathrm{s}}(\mathrm{g} / \mathrm{g})$ & 0,33 & $0,23 \pm 0,02$ & $0,29 \pm 0,01$ & $0,33 \pm 0,00$ & $0,32 \pm 0,00$ \\
$\mathrm{Q}_{\mathrm{p}}\left(\mathrm{g} \cdot \mathrm{L}^{-1} \cdot \mathrm{h}^{-1}\right)$ & 0,80 & $0,57 \pm 0,04$ & $0,69 \pm 0,01$ & $0,82 \pm 0,01$ & $0,80 \pm 0,01$ \\
\hline
\end{tabular}

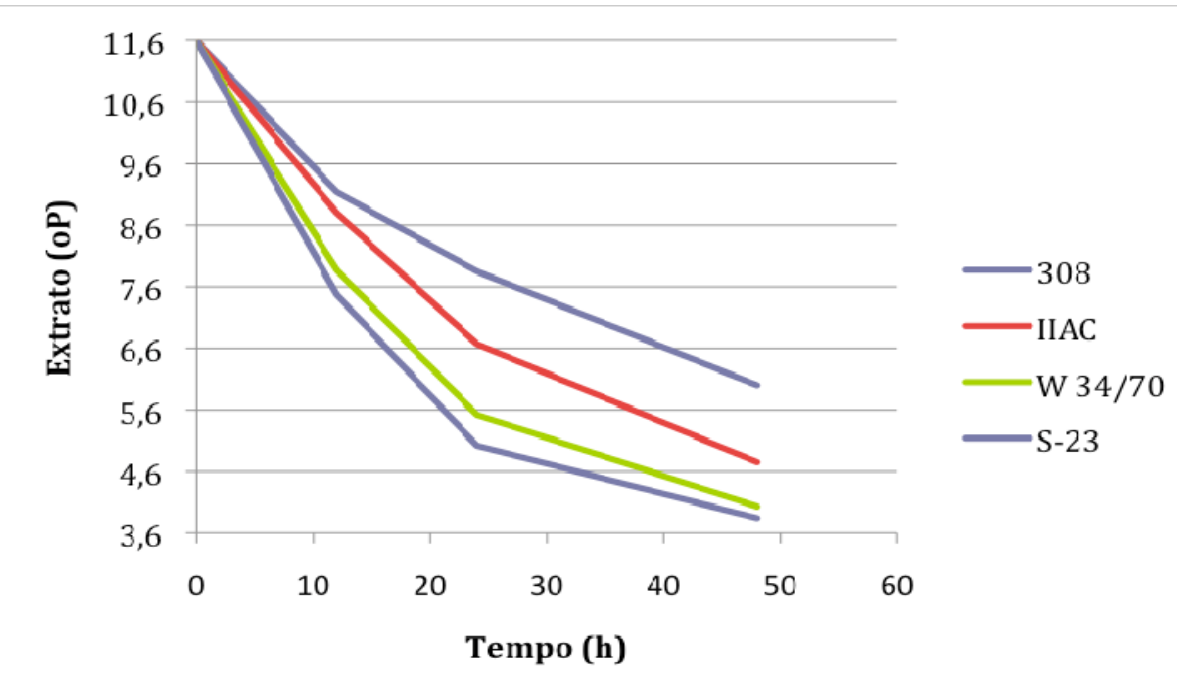

Figura 9. Consumo de açúcares durante o experimento de seleção de leveduras

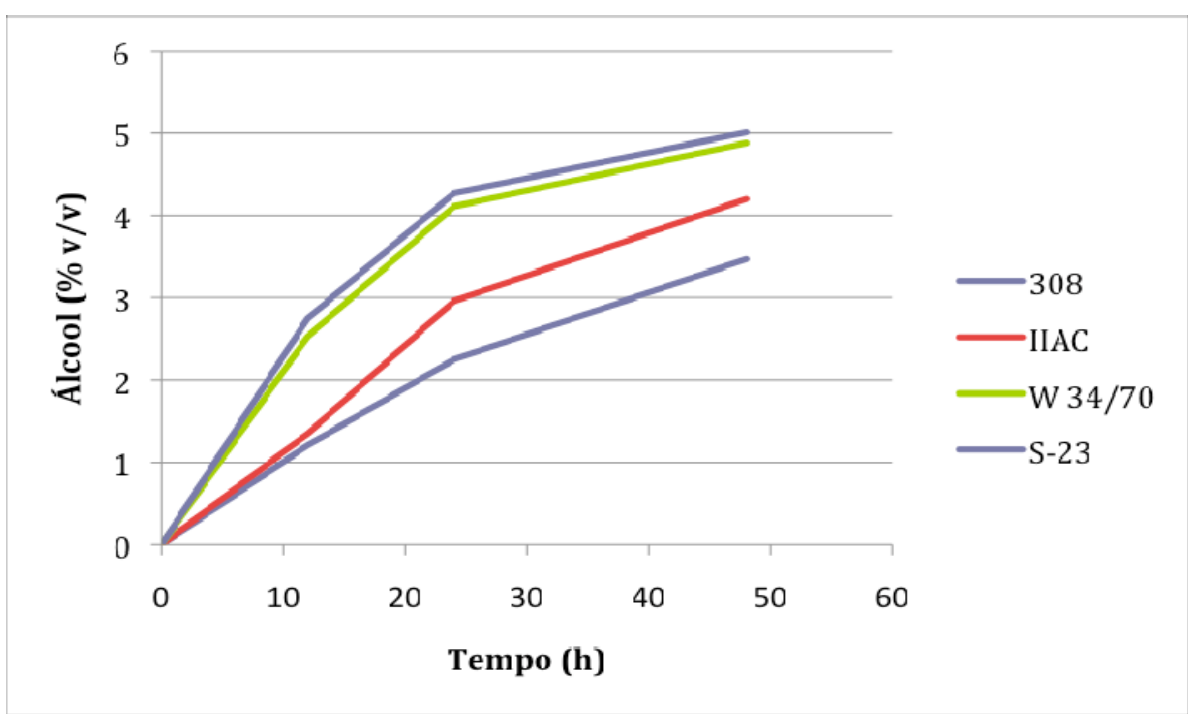


Figura 10. Produção de álcool durante o experimento de seleção de leveduras

A cepa S-23 apresentou $Q_{p}$ de $0,82 \pm 0,01 \mathrm{~g} \cdot \mathrm{L}^{-1} \cdot \mathrm{h}^{-1}$, esta produtividade é $44 \%$ maior que o valor apresentado pela cepa 308, variedade que apresentou desempenho dentre as variedades estudadas, 0,57 $\pm 0,04 \mathrm{~g} \cdot \mathrm{L}^{-1} \cdot \mathrm{h}^{-1}$.

Andrade (2007), ao produzir o chope a partir de um mosto com 35\% de arroz preto na formulação com a variedade 308 obteve produtividade de 0,46 \pm 0,01, com a mesma concentração celular inicial de leveduras. Isto sugere que a fermentação conduzida em temperatura de $20{ }^{\circ} \mathrm{C}, 5^{\circ} \mathrm{C}$ maior que a temperatura utilizada por Andrade (2007), pode ter influenciado o desempenho da levedura estudada. Outra hipótese, seria que a mosturação conduzida por Andrade pode ter rendido uma concentração relativamente grande de maltotriose no mosto, 0 que pode levar a uma fermentação mais lenta, já que a maltotriose é mais lentamente absorvida pela levedura (DAY et al., 2002). Durante a brassagem do mosto com $45 \%$ de arroz preto, foi utilizada a temperatura de $63{ }^{\circ} \mathrm{C}$ por 60 minutos, período três vezes mais longo do que em Andrade (2007). Como esta é temperatura ótima para a ação da $\beta$-amilase (HAMILTON; LEWIS, 1974), o rendimento da hidrólise em maltose pode ter sido muito maior, promovendo a melhor absorção dos carboidratos e aumentando a produtividade em álcool da fermentação (DAY et al., 2002).

\subsection{Fermentação em escala piloto}

\subsubsection{Análise físico-química do mosto com $45 \%$ de arroz preto}

Os mostos foram analisados quanto as suas principais características no analisador de bebidas Anton Paar, modelo Beer Analyzer 2 e os resultados são apresentados na Tabela 17.

Segundo a legislação brasileira, a cerveja produzida a partir deste mosto é classificada como cerveja extra, pois tem extrato primitivo entre 12 e $14 \% \mathrm{~m} / \mathrm{m}$ $(13,01 \% \mathrm{~m} / \mathrm{m})$.

A atenuação limite demonstrou que, em média, os valores obtidos neste trabalho foram menores que aqueles obtidos por Andrade (2007), o que sugere uma fermentabilidade maior do mosto com $45 \%$ de arroz preto submetido à hidrólise com enzima exógena, que pode ter contribuído para a melhor eficiência de hidrólise durante a mosturação. Curi (2006) também estudou as características 
físico-químicas de mostos utilizando cevada com adjunto, e estes apresentaram atenuação limite num patamar mais elevado que o presente estudo, entre 3,0 e $3,2^{\circ}$ Brix.

Tabela 17. Análises feitas com os mostos dos 3 lotes produzidos e sua média

\begin{tabular}{lrrrr}
\hline Parâmetro & Lote 1 & Lote 2 & Lote 3 & Média \pm SD \\
\hline Extrato Real $(\% \mathrm{~m} / \mathrm{m})$ & 13,01 & 13,01 & 13,00 & $13,01 \pm 0,01$ \\
Extrato Aparente $\left({ }^{\circ} \mathrm{P}\right)$ & 13,12 & 13,10 & 13,07 & $13,10 \pm 0,03$ \\
Atenuação limite $\left({ }^{\circ} \mathrm{P}\right)$ & 2,93 & 1,91 & 1,82 & $2,22 \pm 0,61$ \\
$\mathrm{pH}$ & 5,40 & 5,50 & 5,30 & $5,4 \pm 0,10$ \\
Extrato Recuperado & 15,17 & 17,21 & 16,49 & $16,29 \pm 1,03$ \\
$(\mathrm{~kg})$ & & & & \\
Eficiência da & 68,64 & 77,88 & 74,61 & $73,71 \pm 4,69$ \\
mosturação $(\%)$ & 110 & 125 & 120 & $118,33 \pm 7,64$ \\
Volume $(\mathrm{L})$ & & &
\end{tabular}

$\mathrm{O}$ pH de 5,4 apresentado pelo mosto estava dentro da especificação listada por Eßlinger (2009), entre 5,4 e 5,6.

Além das análises conduzidas no Beer Analyzer 2, foi feita a análise dos açúcares fermentáveis do mosto por Cromatografia Líquida de Alta Eficiência (CLAE). A tabela 18 apresenta as médias dos resultados em comparação aos resultados de Andrade, (2007).

Tabela 18. Perfil de carboidratos no mosto com arroz preto, comparado com o perfil obtido por Andrade, (2007).

\begin{tabular}{crrrrr}
\hline & \multicolumn{5}{c}{ Concentração $(\mathrm{g} / \mathrm{L})$} \\
\cline { 2 - 6 } Carboidrato & \multicolumn{1}{c}{ Lote 1 } & \multicolumn{1}{c}{ Lote 2} & \multicolumn{1}{c}{ Lote 3} & Média & Andrade, \\
& & & & & $(2007)$ \\
\hline Maltotriose & $18,28 \pm 0,33$ & $18,91 \pm 0,49$ & $19,40 \pm 0,25$ & $18,86 \pm 0,56$ & $24,30 \pm 0,07$ \\
Maltose & $75,05 \pm 1,03$ & $76,63 \pm 1,39$ & $77,83 \pm 0,46$ & $76,50 \pm 1,39$ & $63,47 \pm 0,99$ \\
Glicose & $9,69 \pm 0,12$ & $9,91 \pm 0,26$ & $10,03 \pm 0,13$ & $9,87 \pm 0,18$ & $17,28 \pm 0,04$ \\
Frutose & $1,24 \pm 0,01$ & $1,73 \pm 0,38$ & $1,76 \pm 0,41$ & $1,58 \pm 0,29$ & $2,24 \pm 0,00$ \\
Fermentáveis & $104,26 \pm$ & $107,17 \pm$ & $109,01 \pm$ & $106,81 \pm 2,52$ & 107,29 \\
& 1,50 & 2,53 & 0,17 & & \\
\hline Dextrinas e outros & \multicolumn{1}{c}{29,6} & 19,2 & 18,3 & $22,37 \pm 6,28$ & 17,95
\end{tabular}


Total geral

133,86

126,37

127,31

129,18

125,24

O perfil de carboidratos do mosto obtido com arroz preto foi calculado e comparado ao perfil encontrado por Briggs et al. (2004) e por Andrade, (2007), cujos resultados estão apresentados na Tabela 19.

Tabela 19. Perfil centesimal de carboidratos no mosto.

\begin{tabular}{lrrr}
\hline \multicolumn{1}{c}{ Carboidrato } & $\begin{array}{c}\text { Arroz preto } \\
45 \%\end{array}$ & $\begin{array}{c}\text { Briggs et al. } \\
(2004)\end{array}$ & Andrade, (2007) \\
\hline Maltotetraose (\%) & - & 6,1 & - \\
Maltotriose (\%) & 17,65 & 14,0 & 19,40 \\
Maltose (\%) & 71,62 & 41,1 & 50,68 \\
Sacarose (\%) & - & 5,5 & - \\
Glicose (\%) & 9,24 & 8,9 & 13,80 \\
Frutose (\%) & 1,48 & - & 1,79 \\
Dextrinas e Outros (\%) & $22,37^{*}$ & 22,2 & 14,33 \\
Total & 100,0 & 97,8 & 100,0 \\
\hline
\end{tabular}

* Teor de açúcares não fermentáveis presentes no mosto com $45 \%$ de arroz preto

O maior teor de maltose obtido no presente estudo é resultado, principalmente, da fase de hidrólise da $\beta$-amilase do malte, que em torno de 63 ${ }^{\circ} \mathrm{C}$, hidrolisa tanto $\mathrm{o}$ amido do malte quanto as dextrinas disponibilizadas pela hidrólise prévia do arroz preto, quando atua a $\alpha$-amilase termoestável (HAMILTON; LEWIS, 1974).

O teor de glicose obtido no presente trabalho, de 9,24 $\mathrm{g} / \mathrm{L}$, foi muito próximo do teor preconizado por Briggs et al (2004), de 8,9 g/L. De certa forma, esta baixa concentração de glicose é favorável à fermentação, pois em um perfil padrão de fermentação, a glicose é utilizada rapidamente, restando apenas maltose e maltotriose no mosto. Como os dois açúcares permeam a célula da levedura pelo mesmo mecanismo, é natural que haja competição pelo receptor da permease. Esta alta disponibilidade de maltose favorece a absorção de carboidratos pelas leveduras, e leva a um alto rendimento em álcool, pois a relação entre a absorção de maltose e maltotriose é de aproximadamente 4:1 (DAY et al., 2002). Além de que o rendimento da conversão de glicose, maltose e maltotriose em álcool é de $0,51 \mathrm{~g} / \mathrm{g}, 0,53 \mathrm{~g} / \mathrm{g}$ e $0,55 \mathrm{~g} / \mathrm{g}$, respectivamente 


\subsubsection{Análise físico-química da cerveja.}

Os resultados das análises físico-químicas dos três lotes de cerveja produzidos estão apresentados na Tabela 20.

Tabela 20. Análises físico-químicas dos 3 lotes de cerveja com $45 \%$ de arroz preto ao final da fermentação.

\begin{tabular}{lrrrr}
\hline \multicolumn{1}{c}{ Análise } & Lote 1 & Lote 2 & Lote 3 & Média \pm SD \\
\hline Álcool $(\%$ v/v) & 5,57 & 5,47 & 5,02 & $5,35 \pm 0,29$ \\
Extrato Real $(\% \mathrm{~m} / \mathrm{m})$ & 4,91 & 3,86 & 3,63 & $4,13 \pm 0,68$ \\
Extrato Original $\left({ }^{\circ} \mathrm{P}\right)$ & 13,29 & 12,18 & 11,30 & $12,26 \pm 1,00$ \\
Extrato Aparente ( $\left.{ }^{\circ} \mathrm{P}\right)$ & 2,93 & 1,91 & 1,82 & $2,22 \pm 0,62$ \\
Grau Real Fermentação (\%) & 64,73 & 69,67 & 69,20 & $67,87 \pm 2,73$ \\
Grau Aparente de Ferm (\%) & 77,95 & 84,33 & 83,86 & $82,05 \pm 3,56$ \\
pH & 4,57 & 4,49 & 4,56 & $4,54 \pm 0,04$ \\
Cor (EBC) & 17,08 & 17,22 & 16,89 & $17,06 \pm 0,17$ \\
Rendimento (g/g) & 0,41 & 0,36 & 0,34 & $0,37 \pm 0,04$ \\
Eficiência Fermentação (\%) & 80,67 & 71,16 & 65,62 & $72,48 \pm 7,61$ \\
Produtividade (g.L-1.h-1) & 0,29 & 0,33 & 0,33 & $0,32 \pm 0,02$ \\
\hline
\end{tabular}

O produto obtido no presente estudo pode ser classificado, segundo a legislação brasileira de bebidas alcoólicas, como uma Cerveja Pilsen Extra, Clara, de Baixa Fermentação, porque foi formulada com 55 \% de malte proporção mínima de malte exigida por lei para que seja denominada cerveja em relação ao extrato primitivo; com malte tipo Pilsen, a partir de um mosto com teor de extrato primitivo entre 12 e $14 \%$ m/m; apresentando uma média de 17,06 unidades EBC de cor, abaixo do mínimo de 20 unidades EBC para ser considerada escura; e fermentada com a levedura Saflager S-23, cepa comercial de baixa fermentação (BRASIL, 2009).

Os teores de Extrato Real e Aparente se situaram dentro da faixa citada por Compton (1978) - 3,7 a 4,8 \% para o Extrato Real e 2,0 a 3,1 ${ }^{\circ} \mathrm{P}$ para o Extrato Aparente, diferentemente de Andrade (2007), que obteve resultados acima da especificação citada, 5,05 \% e 3,20 ${ }^{\circ} \mathrm{P}$, respectivamente.

O grau real de fermentação obtido, 67,87 \%, ficou acima do obtido por Andrade (2007), que foi de 61,69 \%. Curi (2006) obteve um grau real de 
fermentação entre 59,72 e 62,50 \% nas formulações de suas cervejas. Novamente, a explicação para a melhor fermentabilidade do mosto se dá pelas condições de mosturação às quais o mosto foi submetido, principalmente em relação ao tempo em $63^{\circ} \mathrm{C}$.

O pH da cerveja, 4,54 $\pm 0,04$, seguiu a tendência apresentada por Eßlinger, (2009), que cita que o pH deve estar entre 5,4 e 5,6 no mosto e entre 4,3 e 4,6 após a fermentação. $\mathrm{O}$ pH abaixo de 4,2 deve ser evitado, para que a cerveja não apresente sabor ácido. Por outro lado, um aumento no pH após a fermentação pode indicar autólise das leveduras, o que pode trazer prejuízo sob ponto de vista sensorial à cerveja.

A cor apresentada pela cerveja obtida, 17,06 \pm 0,17 EBC, ficou abaixou da obtida por Andrade (2007), que apresentou 26,33 0 0,41 EBC. Apesar da cerveja obtida ter mais arroz preto na fórmula, pode ter ocorrido maior adsorção das antocianinas pelas leveduras, já que se trata de cepas diferentes nos dois estudos. Porém, o resultado obtido no presente trabalho é maior que o resultado obtido por Curi (2006), que cita o valor de 11,4 EBC para uma cerveja puro malte e 8,1 EBC para a cerveja produzida com cevada como adjunto.

Os parâmetros fermentativos apresentaram resultados bastante similares aos resultados de Andrade (2007). A Tabela 21 apresenta os resultados dos estudos obtidos no presente trabalho e aqueles encontrados por Andrade, (2007).

Tabela 21. Parâmetros Fermentativos do estudo, em comparação com Andrade (2007)

\begin{tabular}{ccc}
\hline Parâmetro Fermentativo & Cerveja arroz preto 45\% & Andrade, (2007) \\
\hline Rendimento $\left(\mathrm{Y}_{\mathrm{p} / \mathrm{s}}\right)(\mathrm{g} / \mathrm{g})$ & $0,37 \pm 0,04$ & 0,36 \\
Eficiência de fermentação (\%) & $72,48 \pm 7,61$ & 70,92 \\
Produtividade em álcool $\left(\mathrm{g} \cdot \mathrm{L}^{-1} \cdot \mathrm{h}^{-1}\right)$ & $0,32 \pm 0,02$ & 0,34 \\
\hline
\end{tabular}

As Figuras 11 a 15 ilustram o consumo de açúcar e a produção de álcool em cada lote de fermentação e as comparações entre si. 


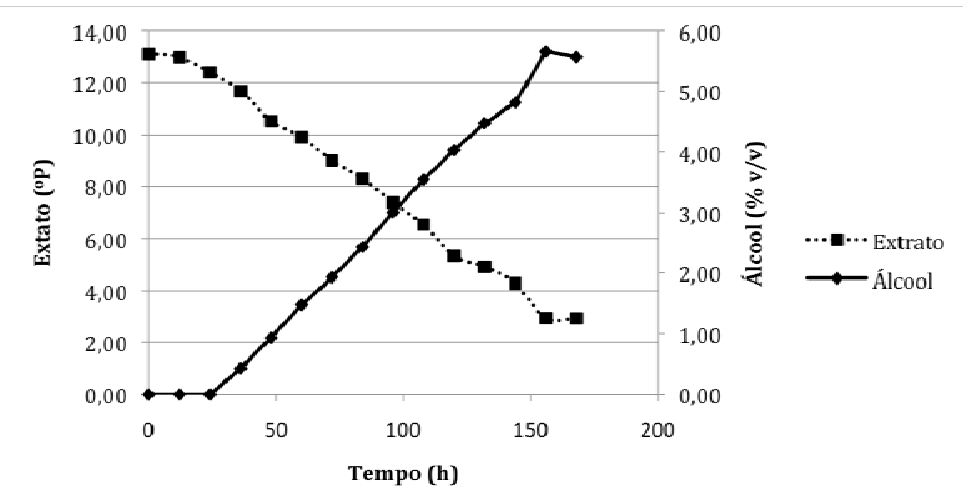

Figura 11.Perfil do consumo de açúcares e produção de álcool durante as 168 h de fermentação do lote 1.

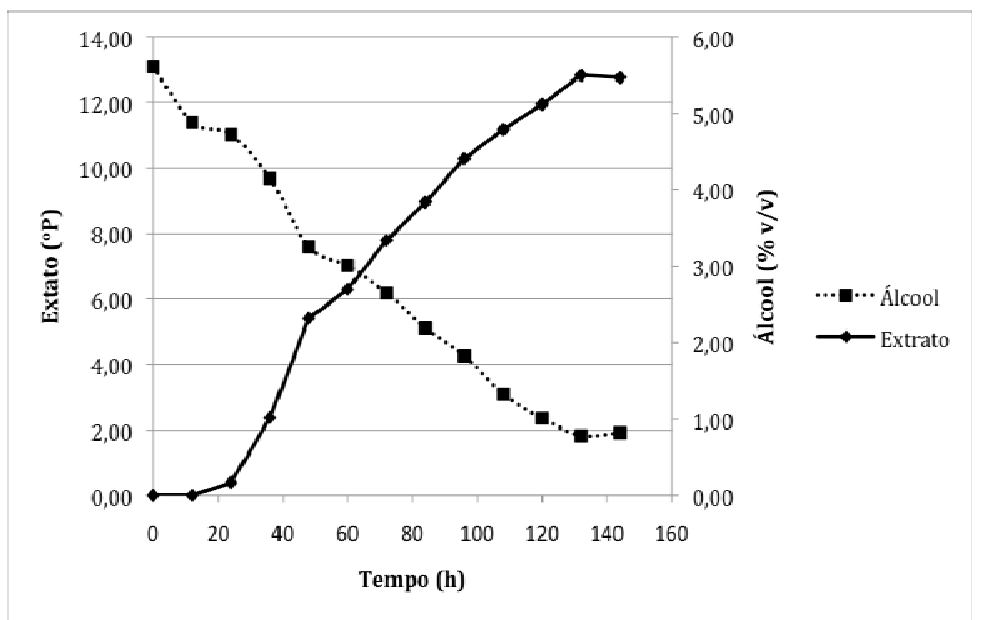

Figura 12. Perfil do consumo de açúcares e produção de álcool durante as $144 \mathrm{~h}$ de fermentação do lote 2.

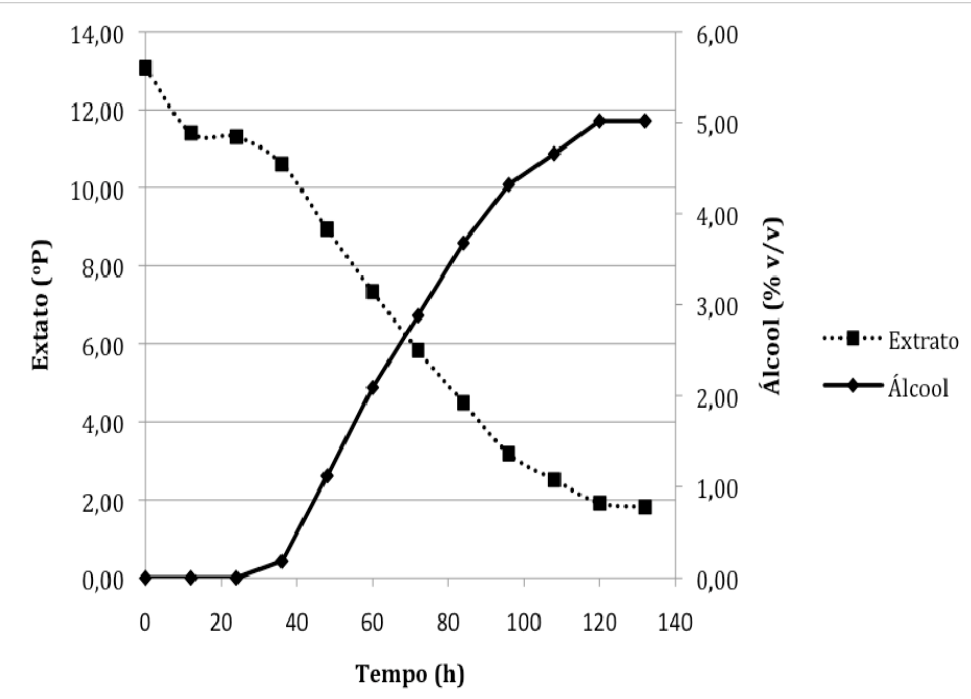

Figura 13. Perfil do consumo de açúcares e produção de álcool durante as $132 \mathrm{~h}$ de fermentação do lote 3. 


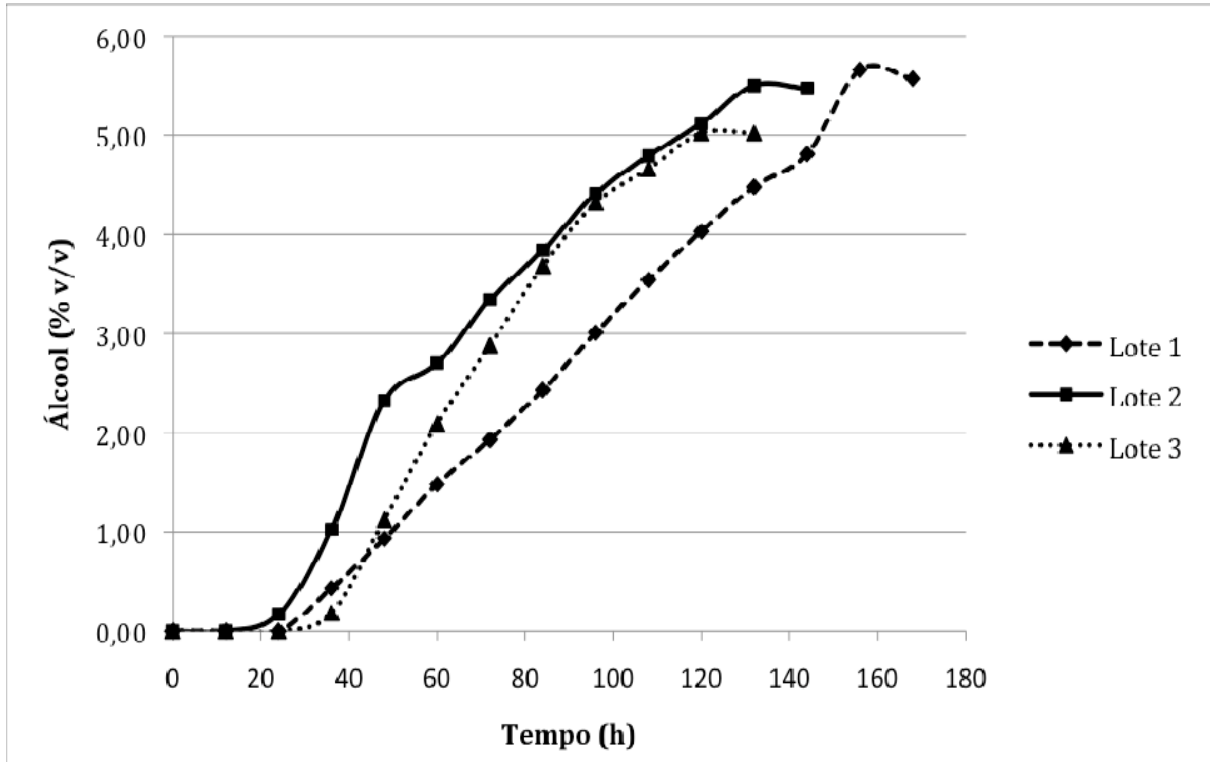

Figura 14. Gráfico comparativo do perfil da produção de álcool durante as 3 fermentações.

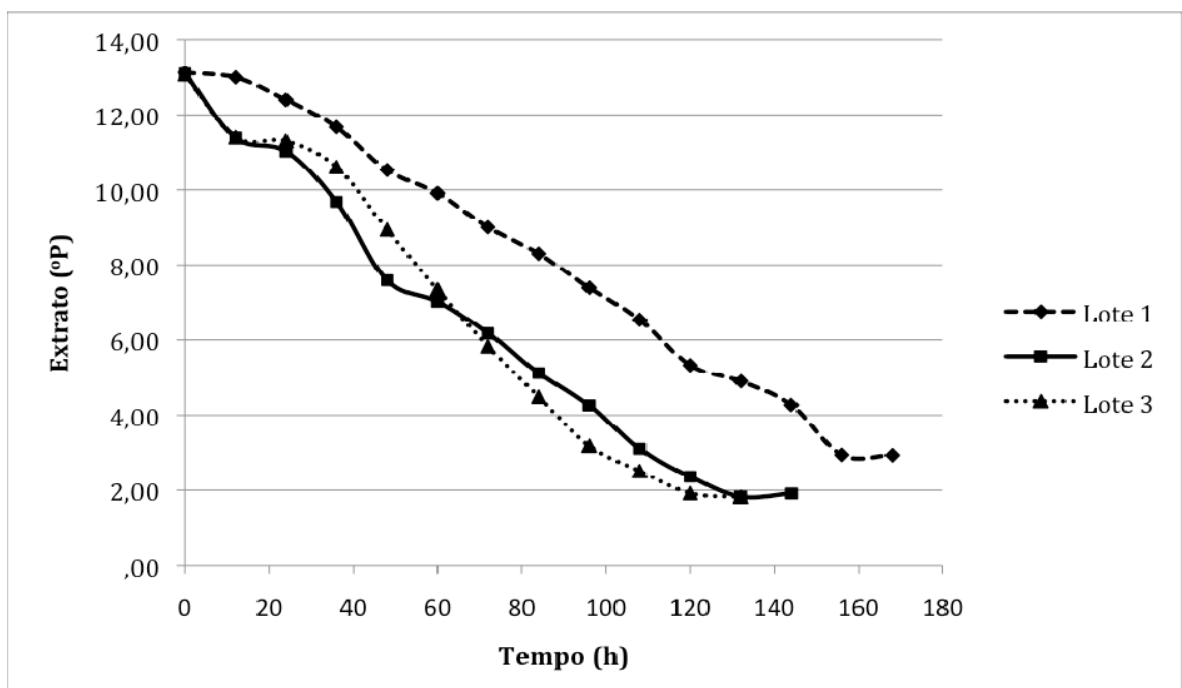

Figura 15. Gráfico comparativo do perfil de consumo de açúcares com as 3 fermentações.

Observa-se que no lote 1 que seu perfil de consumo de açúcares A Figura 16 apresenta a cerveja obtida pelo processo proposto no presente trabalho. 


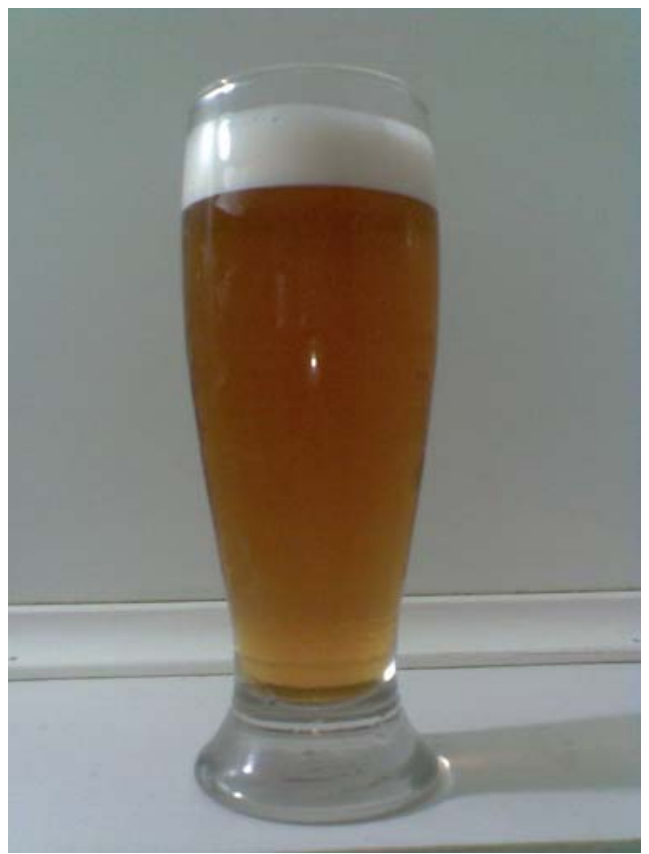

Figura 16. Cerveja produzida utilizando o hidrolisado de arroz preto como adjunto

Observa-se uma cor acastanhada e uma espuma bastante consistente, principais características da cerveja feita com este adjunto (ANDRADE, 2007)

\subsubsection{Análise microbiológica da cerveja.}

O acompanhamento microbiológico foi feito durante a fermentação dos lotes de cerveja, e a média dos resultados estão ilustrados na Figura 17. Não houve contaminação bacteriana relevante em qualquer das 3 cervejas produzidas.

Nota-se que o declínio do número de células suspensas no meio de fermentação coincide com a diminuição da produção de álcool, aproximadamente em 120 horas, isto ocorre como consequência da combinação da depleção de nutrientes e dos efeitos tóxicos do etanol (BOULTON; QUAIN, 2001).

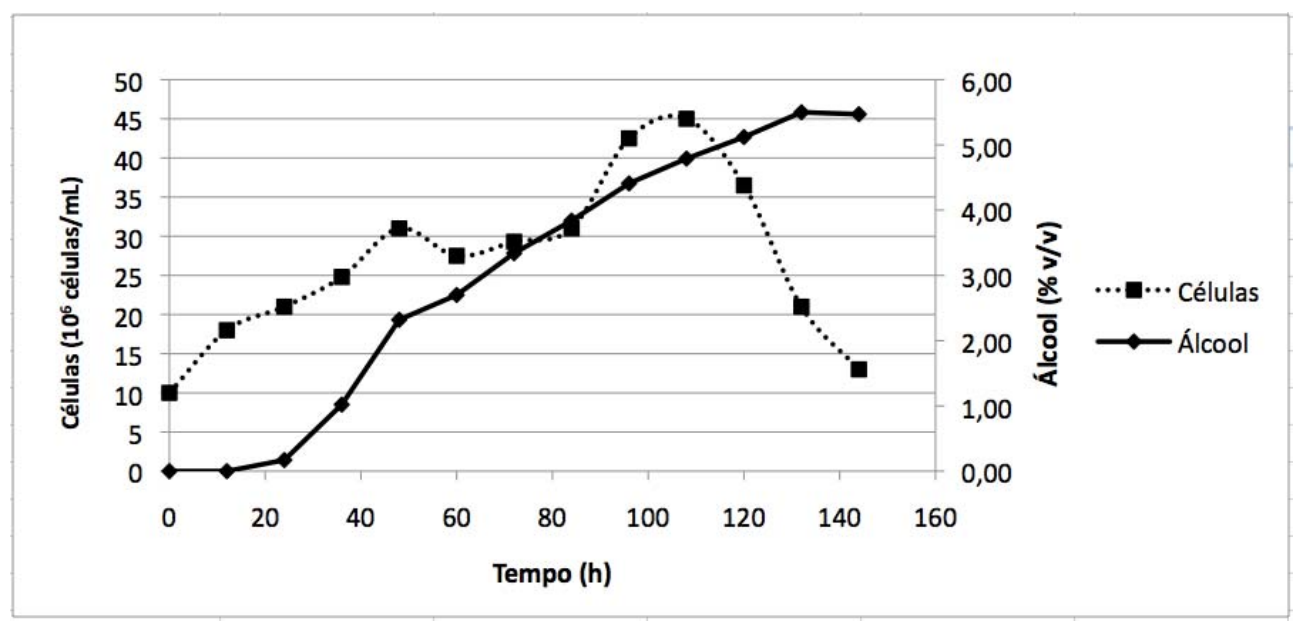

Figura 17. Número de células suspensas em relação à produção de álcool durante a fermentação. 


\subsection{Análise Sensorial}

\subsubsection{Caracterização dos provadores}

O painel de provadores formado por 112 consumidores comuns, nãotreinados, foi distribuído da seguinte forma:

Sexo: 76 homens e 36 mulheres

Idade: entre 18 e 60 anos

A distribuição etária dos grupos está ilustrada na Figura 18.

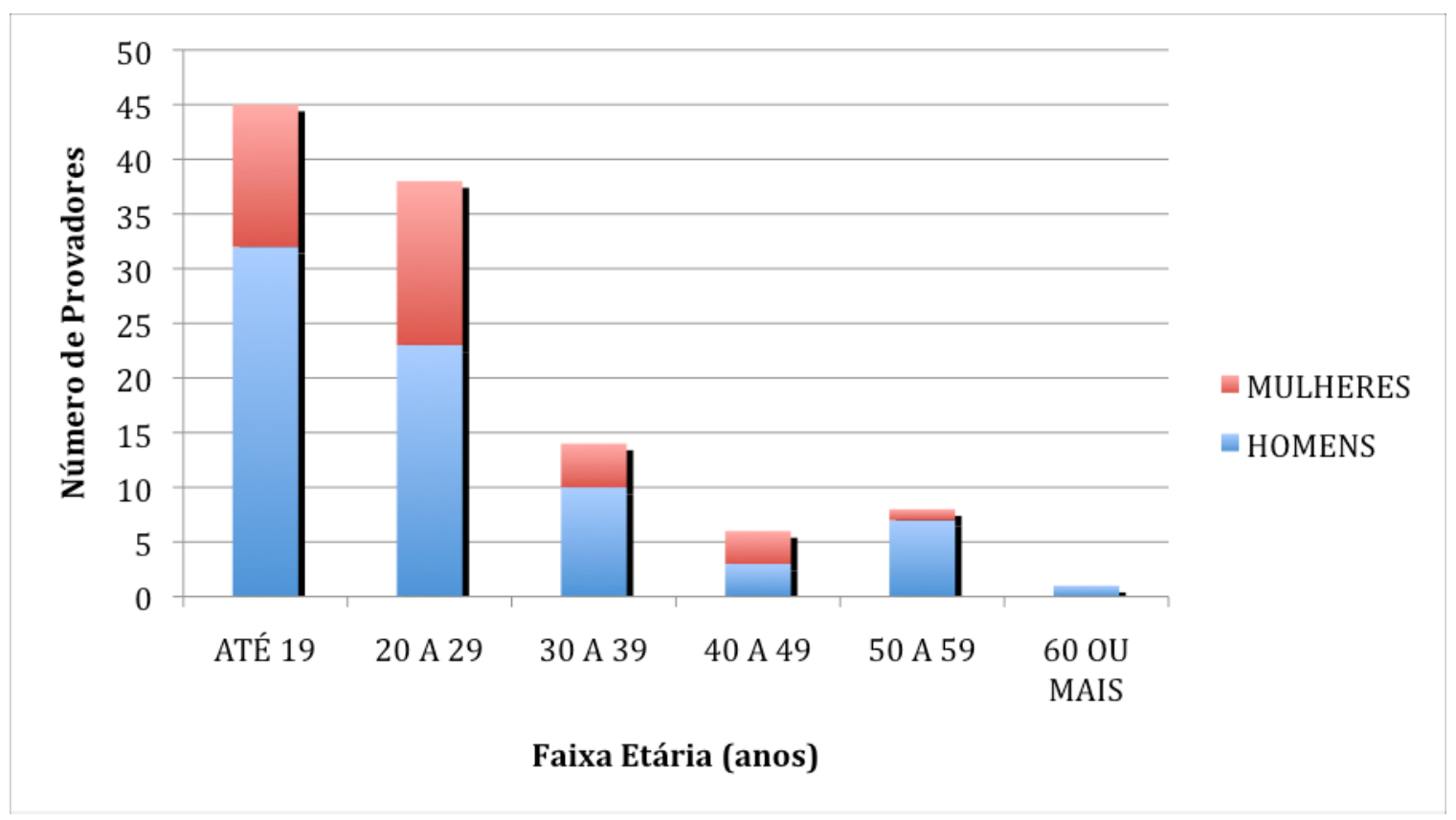

Figura 18. Distribuição dos provadores por faixa etária e sexo.

Observa-se que o público da faixa etária entre 18 e 29 anos representa $74,1 \%$ do universo de provadores. A população dividida entre homens e mulheres representa, entre os provadores, $67,9 \%$ e $32,1 \%$, respectivamente.

\subsubsection{Teste de Preferência}

Foram aplicados 63 testes de preferência aos alunos e funcionários da EEL, dentre os quais, 22 mulheres e 41 homens. Foram atribuídas notas entre $1 \mathrm{e}$ 9 a duas amostras de cerveja oferecidas, uma pasteurizada e uma nãopasteurizada (chope), de acordo com a escala hedônica. Também responderam se comprariam alguma das duas cervejas oferecidas, e se sim, qual delas. Entre os consumidores que responderam que comprariam alguma das cervejas apresentadas no teste, 18 preferiram a amostra de chope, 19 comprariam a 
cerveja e 6 responderam que comprariam ambas. De acordo com a tabela específica para o teste (ASBC, 1996), não há diferença estatística entre as cervejas testadas em qualquer nível de confiança. Os resultados estão apresentados nas Tabelas 22 e 23.

Tabela 22. Teste de aceitação, com as respostas divididas entre homens e mulheres

\begin{tabular}{|c|c|c|c|c|c|c|}
\hline \multirow[b]{2}{*}{ Compraria? } & \multicolumn{2}{|c|}{ Homens } & \multicolumn{2}{|c|}{ Mulheres } & \multicolumn{2}{|c|}{ Total } \\
\hline & Respostas & $\begin{array}{l}\% \text { entre } \\
\text { homens }\end{array}$ & Respostas & $\begin{array}{c}\% \text { entre } \\
\text { mulheres }\end{array}$ & Respostas & $\begin{array}{l}\% \text { do } \\
\text { Total } \\
\end{array}$ \\
\hline $\operatorname{Sim}(\%)$ & 27 & 65,9 & 16 & 72,7 & 43 & 68,3 \\
\hline $\begin{array}{l}\text { Não }(\%) \\
\text { Não respondeu }\end{array}$ & 12 & 29,3 & 6 & 27,3 & 18 & 28,6 \\
\hline$(\%)$ & 2 & 4,9 & 0 & 0,0 & 2 & 3,2 \\
\hline Total (\%) & 41 & 100,0 & 22 & 100,0 & 63 & 100,0 \\
\hline
\end{tabular}

Tabela 23. Teste de preferência, entre os provadores que comprariam a cerveja

\begin{tabular}{lrrrrrrr}
\hline & \multicolumn{2}{c}{ Homens } & \multicolumn{2}{c}{ Mulheres } & \multicolumn{2}{c}{ Total } \\
\cline { 2 - 8 } \multicolumn{1}{c}{ Qual? } & \multicolumn{3}{c}{ \% } & \multicolumn{1}{c}{$\%$} & M do \\
\hline \% Pasteurizada & 12 & 44,4 & 7 & 43,8 & 19 & 44,2 \\
\% Não Pasteuriz. & 11 & 40,7 & 7 & 43,8 & 18 & 41,9 \\
Ambas & 4 & 14,8 & 2 & 12,5 & 6 & 14,0 \\
Total & 27 & 100,0 & 16 & 100,0 & 43 & 100,0 \\
\hline
\end{tabular}

Ainda, entre os consumidores que comprariam a cerveja, as notas atribuídas à cerveja e ao chope não apresentaram diferença estatística quando submetidas ao Teste $t$ de Student, pois o $t$ calculado foi de 0,302. Os resultados estão apresentados na Tabela 24.

Tabela 24. Notas médias das amostras entre os consumidores que comprariam a cerveja.

\begin{tabular}{cc}
\hline Amostra & Notas médias \pm Desvio Padrão \\
\hline Pasteurizado & $7,19 \pm 1,30$ \\
Não-Pasteurizado & $6,88 \pm 1,61$ \\
Teste t de Student & $0,302<\mathrm{t}_{\text {crítico }}$ em $5 \%$ \\
\hline
\end{tabular}

Estas notas mostram que as amostras tiveram uma aceitação num nível da escala hedônica entre "gostei regularmente" e "gostei muito" para a cerveja e o chope foi aceito em um nível entre "gostei pouco" e "gostei moderadamente".

Em relação aos consumidores que não comprariam qualquer das amostras, as notas atribuídas ao chope e à cerveja também não apresentaram diferença 
estatística no Teste $t$ de Student, as médias de nota para o chope e para a cerveja foram 4,15 $\pm 1,76$ e 4,40 $\pm 1,35$, respectivamente. As notas atribuídas, mostram que ambas as amostras tiveram avaliação entre "desgostei pouco" e "nem gostei, nem desgostei".

\subsubsection{Teste de Aceitação}

Foi conduzido um teste de aceitação entre alunos e funcionários da EEL, apenas com o chope, num total de 112 provadores, não treinados. Os resultados analisados mostram que o chope teve aceitação geral pelos provadores entre "gostei pouco" e "gostei "regularmente", com a média das notas em 6,29 \pm 1,79. Entre os provadores que comprariam o chope, a aceitação foi entre "gostei regularmente" e "gostei muito", com a média das notas em 7,29 \pm 1,06. 


\section{CONCLUSÕES}

Os resultados obtidos no estudo de melhor condição de hidrólise do arroz preto com extrato enzimático apresentou tempo e concentração de enzima abaixo dos preconizados pelo fabricante.

A enzima utilizada no processo mostrou-se própria ao fim a que se destinava, fazendo com que o rendimento da mosturação fosse similar ou superior a outras cervejas listadas na literatura.

A mosturação com arroz preto previamente hidrolisado apresentou bom rendimento quando comparado a uma mosturação feita apenas com malte. Fazendo com que o arroz preto possa ser considerado uma ótima opção de adjunto de malte na obtenção de uma cerveja especial.

O rendimento em álcool, a eficiência da fermentação foram excelentes e a produtividade em álcool foi bastante satisfatória, tanto nos experimentos em escala de bancada quanto na escala piloto.

Não houve sinais de que os compostos fenólicos do arroz preto pudessem ter inibido a fermentação.

Do ponto de vista sensorial, a cerveja obtida no presente estudo apresenta sabor agradável e intenso, similar a cervejas consumidas no inverno, porém diferente de qualquer exemplar existente no mercado.

\section{Sugestões para futuros trabalhos}

Realizar estudos para que se conheça melhor as propriedades funcionais do arroz preto IAC 600.

Realizar um estudo aprofundado de análise sensorial da cerveja utilizando equipes treinadas por meio da técnica de Análise Descritiva Quantitativa.

Avaliar a manutenção da capacidade antioxidante da cerveja feita com arroz preto ao longo de sua vida de prateleira 


\section{REFERÊNCIAS}

AEHLE, W. Industrial Enzymes. In: Enzymes in Industry. 3 ed. Weinheim: Wiley-VCH Verlag GmbH \& Co. KGaA, 2007. cap. 5, p. 99-262.

AGÊNCIA BRASIL. Setor de microcervejarias cresce no Brasil. Tendencias e mercado. Disponível em http://www.tendenciasemercado.com.br/negocios/setor-de-microcervejarias-cresceno-brasil/. Acesso em 05 jul. 2010.

AGÊNCIA ESTADO. Microcervejarias procuram variedade. Portal Último Segundo. Disponível em

http://ultimosegundo.ig.com.br/economia/2008/08/04/microcervejarias buscam variedade 149319 6.html. Acesso em 05 jul. 2010.

ALMEIDA e SILVA, J.B. Tecnologia de Bebidas: matéria prima, processamento, BPF / APPCC, legislação e mercado. In:Venturini Filho,W.G. Cerveja. São Paulo: Edgard Blucher, 2005.

ALMEIDA, R.B. Avaliação dos fatores que influenciam na concentração de dicetonas vicinais na cerveja produzida pelo processo de alta densidade com utilização de planejamento de experimentos. 1999. 96f. Dissertação (Mestrado em Biotecnologia Industrial) Faculdade de Engenharia Química de Lorena, Lorena.

ALVAREZ, E.; CANCELA, M.A.; CORREA, J.M.; NAVAZA, J.M.; RIVEROL, C. Fuzzy logic control for the isomerized hop pellets production. Journal of Food Engineering. v. 39, p. 145-150. 1999

ANDRADE, C. M. Obtenção de chope utilizando arroz preto (Oryza sativa) como adjunto de malte. 2007. f.78. Dissertação (Mestrado em Biotecnologia Industrial) - Escola de Engenharia de Lorena, Universidade de São Paulo, Lorena, 2007.

ANGELINO, S.A.G.F. Beer. In: MAARSE, H. Volatile Compounds in Foods and Beverages. New York: Marcel Dekker, 1991. p.580-599.

ANGER, H.M.; SCHILDBACH, S.; HARMS, D.; PANKOKE, K. Analysis and Quality Control. In EßLINGER, H.M.: Handbook of Brewing. Weinheim, Germany: WILEY-VCH, 2009. p. $437-473$

APAR, D. K.; ÖZBEK, B. a-Amylase inactivation during rice starch hydrolysis. Process Biochemistry. v.40, n. 3-4, p.1367-1379, 2005.

ASBC - Methods of Analysis of the American Society of Brewing Chemists. $8^{\text {th }}$ Rev. Ed. Minnesota: The Technical Committee and the Editorial Committe of the ASBC, 1996.

AZEREDO, D.P. Síntese e degradação de glicogênio e viabilidade de levedura cervejeira. 1999. 103 p. Dissertação (Mestrado em Ciências) - Universidade Federal do Rio de Janeiro. Rio de Janeiro.

BASSINELO, P.Z.; KOAKUZO, S.N.; SOARES, L.A.; FERREIRA, R.A. Determinação da qualidade de grãos em arroz preto. In: CONGRESSO BRASILEIRO DE QUÍMICA. 48. 2008. Rio de Janeiro. Resumos... Rio de Janeiro. 2008a. Disponível em http://www.abq.org.br/cbq/2008/trabalhos/10/10-481-2358.htm. Acesso em 10 ago. 2010.

BASSINELO, P.Z.; GARCIA, J.S.; SOARES, L.A.; KOAKUZU, S.N.; NETO, F.P.M.; FERREIRA, R.A.; MENDONÇA, J.A.; SANTIAGO, C.M.; RANGEL, P.H.N. ARROZ PRETO: nova opção culinária para o Brasil. Comunicado Técnico Embrapa. n. 147, p. 1-6, 2008 b. 
BeMILLER, J.M.; WHISTLER, R.L. Starch, Chemistry and Technology. $3^{\text {rd }}$ ed. London: Elsevier Academic, 2009. 879p.

BILIADERIS, C.G. The structure and interactions of starch with food constituents. Canadian Journal of Physiology and Pharmacology. v.69, p.60-78, 1991.

BIOTECNOLOGIA
<http://www.biotecnologia.com.br/bionoticias/noticia.asp?id=1400> Acesso em 18 out. 2010.

BOULTON, C.; QUAIN, D. Biochemistry of fermentation. In:

Fermentation. London: Blackwell Science Ltd, 2001. cap. 3, p. 69-142.

Brewing Yeast and

BRASIL. Decreto n. 6871, de 04 de junho de 2009. Regulamenta a Lei $n^{\circ} 8.918$, de 14 de julho de 1994, que dispõe sobre a padronização, a classificação,o registro, a inspeção e fiscalização de bebidas. Diário Oficial da União. Brasília, DF, 05 jun. 2009. Disponível em <http://www.planalto.gov.br/ccivil_03/_Ato2007-2010/2009/Decreto/D6871.htm>. Acesso em: 05 jul. 2010.

BRIGGS, D.E.; BOULTON, C.A.; BROOKES, P.A; STEVENS, R. Brewing - Science and Practice. Cambridge, England: Woodhead Publishing. 2004.

BULÉON, A.; COLONNA, P.; PLANCHOT, V.; BALL, S. Starch granules: structure and biosynthesis. International Journal Biological Macromolecules, v.23, p.85-112, 1998.

BVOCHORA, J.M.; ZVAUYA, R. Biochemical changes occurring during the application of high gravity fermentation technology to the brewing of Zimbabwean traditional opaque beer. Process Biochemistry, v.37. p. 365-370. 2001.

BVOCHORA, J.M.; DANNER, H.; MIYAFUJI, H.; BRAUN,R.; ZVAUYA, R. Variation of sorghum phenolic compounds during the preparation of opaque beer. Process Biochemistry, v.40. p. 1207-1213. fev./abr. 2004.

CARGILL. Tecnologia, Uso e Potencialidades de Tuberosas Amiláceas Latino Americanas. In: Cultura de Tuberosas Amiláceas Latino Americanas. São Paulo: Fundação Cargill, 2003. v.3, cap.15, p.377-449.

CARVALHO, G. B. M.; BENTO, C. V.; ALMEIDA e SILVA; J.B. Elementos biotecnológicos fundamentais no processo cervejeiro: $1^{\text {a }}$ Parte - As leveduras. Revista Analytica, v.5, n.25. p. 3642. 2005.

CARVALHO, G. B. M. Obtenção de cerveja usando banana como adjunto e aromatizante. 2009. 163f. Tese (Doutorado em Biotecnologia Industrial) - Escola de Engenharia de Lorena, Universidade de São Paulo, 2009.

CASTRO, E.M.; FERREIRA, C.M.; MORAIS, O.P. Qualidade de grãos e competitividade do arroz de terras altas. In: CONGRESSO DA CADEIA PRODUTIVA DE ARROZ, 1., REUNIÃO NACIONAL DE PESQUISAS DE ARROZ, 7., 2002, Florianópolis. Anais... Santo Antônio de Goiás: Embrapa Arroz e Feijão, 2003. p. 220-233.

CEREDA, M.P. Cervejas. In: AQUARONE, E.; LIMA, U.A.; BORZANI, W. Alimentos e Bebidas Produzidos por Fermentação. São Paulo: Edgar Blucher, p.3-78, 1983.

CHEUN, P.N.; KUO, W.H.; CHIANG,C.L.; CHIOU, H.L.; HSIEH, Y.S.; CHU,S.C. Black rice anthocyanins inhibit cancer cells invasion via repressions of MMPs and u-PA expression. Chemico-Biological Interactions, v.163, p.18-229. 2006.

CHOI, Y.; JEONG, H.S.J.; LEE, J. Antioxidant activity of methanolic extracts from some grains consumed in Korea. Food Chemistry, v.103, p. 130-138. 2007. 
CODONÊR, P. Actividad antioxidante de la fracción polifenólica de la cerveza. In: I Simpósio Internacional de La Cerveza. 2002, España.

COMPTON, J. Beer quality and taste methodology. In: BRODERICK, H.M. (Ed.) The practical brewer: a manual for the brewing industry. $2^{\text {nd }}$.ed. Madison: Impressions, 1978. cap.15, p.288-308.

CONCENÇO, G; FERREIRA, E.A.; FERREIRA, F.A.; SANTOS, J.B. Plasmodesmos: Transporte simplástico de herbicidas na planta. Planta Daninha, Viçosa-MG, v. 25, n. 2, p. 423-432, 2007

COTELLE, N. Role of flavonoids in oxidative stress. Current Topics of Medical Chemistry, v.1, n.6, 569-590, 2001.

CURI, R.A. Produção de cerveja utilizando cevada como adjunto de malte. 2006. 110f. Tese (Doutorado em Agronomia/Energia na Agricultura) - Faculdade de Ciências Agronômicas, Universidade Estadual Paulista. Botucatu.

DANCAUSE K.N.; AKOL H.A.; GRAY S.J. Beer is the cattle of women: sorghum beer commercialization and dietary intake of agropastoral families in Karamoja, Uganda. Social science \& medicine. v. 70, p.1123-30. 2010.

DAY, R. E.; ROGERS, P. J.; DAWES, I. W.; HIGGINS, V. J. Molecular Analysis of Maltotriose Transport and Utilization by Saccharomyces cerevisiae. Applied and Environmental Microbiology, v. 68, n. 11, p. 5326-5335, 2002.

DEMUYAKOR, B.; OHTA, Y. Characteristics of single and mixed culture fermentation of Pito beer. Journal of Science and Food Agricultural, v.62. p. 401-408. 1993.

EßLINGER, H.M. Fermentation, Maturation and Storage. In Handbook of Brewing. Weinheim, Germany: WILEY-VCH, 2009. p. $207-224$.

EUROPEAN BREWERY CONVENTION. Analytica-EBC. $5^{\text {th }}$.ed. Zurique: Brauerei und Getränke Rundschau, 2000. 271p.

FAO - Food and Agriculture Organization of the United Nations. $\alpha$-amylase (thermostable) from Bacillus licheniformis containing a modified $\alpha$-amylase gene from $B$. licheniformis http://www.fao.org/ag/agn/jecfa-additives/specs/Monograph1/Additive-027.pdf Acesso em 16 jun. 2010.

FAO - Food and Agriculture Organization of the United Nations. International Year of Rice 2004: Factsheet. Disponível em <http://www.fao.org/rice2004/en/f-sheet/factsheet3.pdf> Acesso em 06 jul. 2010.

FERMENTIS. Especificações técnicas de Saccharomyces cerevisiae Saflager W-34/70, Levedura seca tipo lager. Disponível em <http://www.fermentis.com/FO/pdf/CB/PT/Saflager W34-70 CB PT.pdf> Acesso em 08 abr. 2010.

FILLAUDEAU, L.; BLAINPAIN-AVET, P.; DAUFIN, G. Water, wastewater and waste management in brewing industries, Journal of Cleaner Production, v. 14. p. 463-471, 2006.

FREEMAN, P.L. Cebada e Malteado. In: El Cervecero en la Práctica. $3^{\mathrm{a}}$ ed., Master's Brewers Association of the Americas. St Paul, MN - EUA. 2002. cap. 3. p. $61-85$.

GODOY, J.L. A vez dos “gourmets"!. Revista Rural. São Paulo, v. 91, set. 2005. Disponível em http://www.revistarural.com.br/Edicoes/2005/artigos/rev91 arroz.htm. Acesso em 06 jul. 2010.

GONZALES SAN JOSÉ, M.L.; MUNIZ RODRIGUES, P.; VALL BELLÉS, Y.V. Actividad antioxidante de la cerveza: estudios in vitro e in vivo ( ${ }^{\circ}$ Parte). Cerveza y Salud, v. 154. p. 47-54, 2001. 
GOODE, D.L.; ARENDT, E.K. Pilot scale production of a lager beer from a grist containing $50 \%$ unmalted sorghum. Journal of the Institute of Brewing, v. 109. p. 208-217, 2003.

HAMILTON, D.M.; LEWIS, M.J. Factors affecting wort extract and attenuation. MBAA Technical Quarterly, v. 11, n. 1, p. 31-34, 1974.

HAQ, I. U.; JAVED, M. M.; HAMEED, U.; ADNAN, F. Kinetics and thermodynamic studies of alpha amylase from Bacillus licheniformis mutant. Pakistan Journal of Botany, v. 42, n. 5, p. 35073516. 2010.

HARDWICK, W.A. Handbook of brewing. New York: Marcel Dekker, 1995. 714p.

HEINEMANN, R.J.B.; FAGUNDES, P.L.; PINTO, E.A.; PENTEADO, M.V.C.; LANFER-MARQUEZ, U.M. Comparative study of nutrient composition of commercial brown, parboiled and milled rice from Brazil. Journal of Food Composition and Analysis. v. 18, p. 287-296, 2005.

HOUGH, J.S. Biotechnology of malting and brewing. Cambridge: Cambridge University Press, 1985. p.159.

HU, C.; ZAWISTOWSKI, J.; WENHUA, L.; KITTS, D.D. Black rice (Oryza sativa L. indica) pigmented fractions supress both reactive oxygen species and nitric oxide in chemical and biological model systems. Journal of Agricultural and Food Chemistry, v.1, p.5271-5277. 2003.

IAC - IAC 600: Primeira cultivar de arroz preto para o Estado de São Paulo. O Agronômico, v. 56, n. 1, p. 20. 2004. Disponível em <http://www.iac.sp.gov.br/oagronomico/56_1/cultivaresiac.pdf> Acesso em 11 fev. 2011.

KANEDA, I.; KUBO, F.; SAKURAI, H. Relationship between trace metal concentration and antioxidative activity of ancient rice bran (red and black rice) and a present-day rice bran (Koshihikari). Journal of Trace Elements in Medicine and Biology, v. 21, p. 43-51. 2007.

KOLUSHEVA, T; MARINOVA, A. A study of the optimal conditions for starch hydrolysis through thermostable $\alpha$ - amylase. Journal of the University of Chemical Technology and Metallurgy. v. 42, n.1, p. 93-96, 2007.

KONG, S; LEE, J. Antioxidants in milling fractions of black rice cultivars. Food Chemistry, v. 120, n. 1 , p. $278-281,2010$.

KREISZ, S. Malting. In EßLINGER, H.M. Handbook of Brewing. Weinheim, Germany. WILEY$\mathrm{VCH}, 2009$. p. $147-164$

KROTTENTHALER, M. Hops. In: EßLINGER, H.M. Handbook of Brewing. Weinheim, Germany. WILEY-VCH, 2009. p. $85-104$

KROTTENTHALER, M; GLAS, K. Brew Water. In: EßLINGER, H.M. Handbook of Brewing. Weinheim, Germany. WILEY-VCH, 2009. p. $105-118$.

KUNZE, W. Technology of Brewing and Malting: International Edition, Berlin, VLB, 1996. 726p.

LEWIS, M.J.; YOUNG, T.W. Brewing. London: Chapman \& Hall. 1995. 260p.

LIMA, J.M.B. O sucesso do mercado da cerveja no Brasil e os prejuízos do Sistema de Saúde (público em <http://www.abead.com.br/artigos/arquivos/Artigo290110.pdf>. Acesso em 05 jul.2010.

LNF - Latino America. Termamyl ${ }^{\circledR}$ 2X - Ficha de Informação do produto. Disponível em http://www.Inf.com.br/downloads/termamyl 2x.pdf. Acesso em 16 jun. 2010.

LOWRY, O. H., ROSEBROUGH, N. J.; FARR, A. L.; RANDALL, R. J. Protein measurement with the Folin phenol reagent. Journal of Biological Chemistry. n. 193, p. 265-275. 1951. 
MacGREGOR, A.W.; BAZIN, S.L.; MACRI, L. J.; BABB, J. C. Modelling the Contribution of AlphaAmylase, Beta-Amylase and Limit Dextrinase to Starch Degradation During Mashing. Journal of Cereal Science. v. 29, n.2, p. 161-169. 1999.

MATOS, D.A.; SANTOS, I.J.; COIMBRA, J.S.R.; SILVA, P.H.A. Fécula de batata como adjunto de malte na fabricação de cerveja. Boletim Centro de Pesquisa de Processamento de Alimentos, vol.23, n. 1, p. 161-172. 2005.

MENG, F; WEI, Y; YANG, X. Iron content and bioavailability in rice. Journal of Trace Elements in Medicine and Biology. v. 18, n.4. p.333-338. 2005.

MEUSSDOERFFER, F.; ZARNKOW, M. Starchy Raw Material. In: EßLINGER, H.M. Handbook of Brewing. Weinheim, Germany: WILEY-VCH, 2009. p. $43-84$

MILLER, G.L. Use of de dinitrosalicylic acid reagent for determination of reducing sugar. Analytical Chemistry, Washington, v.31, n.3, p.426-428, 1959.

MIRANDA, C.L.; STEVENS, J.F.; IVANOV, V.; MCCALL, M.; FREI, B.; VEINZER, M.L.; UHLER, D.R. Antioxidant and prooxidant actions of prenylated and non-prenylated chalcones and flavonones in vitro. Journal of Agricultural and Food Chemistry, v.9, n.48, p. 3876-3784, 2000.

MOOL, M. Beers and Coolers. In: BAMFORTH, C.W. Beer: Health and Nutrition. Boston: Blackwell, 2004. p. 50-51.

MORIMITSU, Y; KUBOTA, K.; TASHIRO, T.; HASHIZUME, E.; KAMIYA, T.; OSAWA, T. Inhibitory effect of anthocyanins and colored rice on diabetic cataract formation in the rat lenses. International Congress Series, v. 1245, p. 503-508. 2002.

MUNROE, J.H. Fermentation. In: PRIEST, F.G; STEWART, G.G. Handbook of Brewing. $2^{\text {nd }}$ ed. Boca Raton: Taylor \& Francis, 2006. 853p.

NAKAZAWA, F.; NOGUCHI, S.; TAKAHASHI, J.; TAKADA, M. Gelatinization and Retrogradation of Rice Starch Studied by Differential Scanning Calorimetry. Agricultural and Biological Chemistry, v. 48, n.1, p. 201-203. 1984

NELSON, D.L.; COX, M.M. Lehninger's Biochemistry. $4^{\text {th }}$ ed. New York: W. H. Freeman, 2004. $1119 \mathrm{p}$.

NOEL, S.; LIÉGEOIS, C.; LERMUSIEAU, G.; BODART, E.; BADOT, C.; COLLIN, S. Release of deuterated nonenal during beer aging from labeled precursors synthesized in the boilling kettle. Journal of Agricultural and Food Chemistry, v.47,p. 4323 - 4326, 1999.

NOOTS, I.; DERYCKE, V.; MICHIELS, C.; DELCOUR, J.A.; DELRUE, R.; COPPENS, T. Improvement of Malt Modification by Use of Rhizopus VII as Starter Culture. Journal of Agricultural and Food Chemistry, v.49, 2001. p. $3718-3724$

PALMER, G.H. Barley and Malt. In: PRIEST, F.G; STEWART, G.G. Handbook of Brewing. $2^{\text {nd }}$ ed. Boca Raton, FL. USA. Taylor \& Francis Group. 2006. 853p.

PARRA, C.D. Cervejarias Ampliam para Suportar Crescimento. Engarrafador Moderno, n.157, p.10-17, 2007.

PÉREZ, S.; BALDWIN, P.M.; GALLANT, D.J. Structural Features of Starch Granules I. In: BeMILLER, J.; WHISTLER, R. Starch: Chemistry and Technology. $3^{\text {rd }}$ ed. New York, USA. Academic Press. 2009. Cap. 5. p. $149-192$.

RAO JL, SATYANARAYANA T. Hyperthermostable, $\mathrm{Ca}^{2+}$-independent, and high maltose-forming alpha-amylase production by an extreme thermophile Geobacillus thermoleovorans: whole cell immobilization. Applied biochemistry and biotechnology. v. 159, n.2 p. 464-77. 2009. 
ROSS, H.A.; SUNGURTAS, J.; DUCREUX, L.; SWANSTON, J.S.; DAVIES, H.V.; MCDOUGALL, G.J. Limit dextrinase in barley cultivars of differing malting quality: activity, inhibitors and limit dextrin profiles. Journal of Cereal Science. v. 38, n. 3, p. 325-334. 2003.

RUSSELL, I.; STEWART, G.G. Brewing. In: REHM, H.J.; REED, G. ed. Biotechnology. New York: VCH, v.9, cap.11, 1995.

RUSSELL, I. Yeast. In: PRIEST, F.G; STEWART, G.G. Handbook of Brewing. $2^{\text {nd }}$ ed. Boca Raton: Taylor \& Francis, 2006. 853p.

SÃO PAULO - Disponível em <http://www.saopaulo.sp.gov.br/sis/lenoticia.php?id=73834> Acesso em 18 out. 2006.

SASAKI, T.; YASUI, T.; MATSUKI, J. Effect of Amylose Content on Gelatinization, Retrogradation, and Pasting Properties of Starches from Waxy and Nonwaxy Wheat and Their F1 Seeds. Cereal Chemistry, v. 77, n.1, p.58-63. 2000.

SINDICERV - Sindicato Nacional da Indústria Cervejeira. Disponível em <http://www.sindicerv.com.br/mercado.php> Acesso em 23 jan. 2010.

SLEIMAN, M. Produção de cerveja com extrato de malte nas formas de xarope e pó: análise físico-química, sensorial e energética. 2002. 110f. Dissertação (Mestrado em Agronomia/Energia na Agricultura)-Faculdade de Ciências Agronômicas, Universidade Estadual Paulista, Botucatu.

STEWART, G.G. A Brewer's Delight. Chemistry and Industry, p.706-709, nov, 2000.

SHU, X.; SHEN, S.; BAO, J.; WU, D. Molecular and biochemical analysis of the gelatinization temperature characteristics of rice (Oryza sativa L.) starch granules. Journal of Cereal Science, v. 44, p. 40-48, 2006.

TANAKA, A.; HOSHINO, E. Calcium-binding parameter of Bacillus amyloliquefaciens a-amylase determined by inactivation kinetics. Biochemical Journal, n. 364, p. 635-639. 2002.

TAYLOR, D.G. Water. In: PRIEST, F.G; STEWART, G.G. Handbook of Brewing. $2^{\text {nd }}$ ed. Boca Raton: Taylor \& Francis, 2006. 853p.

TENGE, C. Yeast. In EßLINGER, H.M. Handbook of Brewing. Weinheim, Germany: WILEY-VCH, 2009. p. 119 - 146.

TSCHOPE, E.C. Microcervejarias e Cervejarias. A História, a Arte e a Tecnologia. São Paulo: Editora Aden, 2001. 223 p.

USANSA, U. Beer production from Thai rice. 2008. f. 187. Thesis (Doctor of Philosophy in Biotechnology) - Suranaree University of Technology, Nakhon Ratchasima, Thailand, 2008.

VAN DER MAAREL, M.J.E.C. Starch-processing enzymes. In: WHITEHURST, R.J.; VAN OORT, M. Enzymes in Food Technology. $2^{\text {nd }}$ ed. Ames: Wiley-Blackwell, 2010. cap. 14, p. 320-331.

VENTURINI FILHO, W.G.; CEREDA, M.P. Hidrolisado de fécula de mandioca como adjunto de malte na fabricação de cerveja: avaliação química e sensorial. Ciência e Tecnologia de Alimentos, v.18, n.2, p.156-164, 1998.

VENTURINI FILHO, W. G.; CEREDA, M. P. Cerveja. In: ALMEIDA LIMA, U.; AQUARONE, E.; BORZANI, W.; SCHMIDELL, W. Biotecnologia Industrial. v.4. Biotecnologia na Produção de Alimentos. São Paulo: Edgar Blucher, 2001. p.91-144.

VENTURINI FILHO, W.G. Tecnologia de cerveja. Jaboticabal: Funep, 2000.83p. 
VERSTREPEN, K.J.; DERDELINCKX, G.; VERACHTERT, H.; DELVAUX, F.R. Yeast flocculation: what brewers should know. Applied microbiology and biotechnology, v.61, n.3, p.197-205. 2003.

WALTER, M.; MARCHEZAN, E.; AVILA, L.A. Arroz: composição e características nutricionais. Ciência Rural, v. 38, n. 4, p.1184-1192. 2008.

WANSUKSRI R, CHOTINEERANAT S, PIYACHOMKWAN K. Protein in Rice Flour and Its Effect on Rice Starch Hydrolysis. In: $5^{\text {th }}$ ASIA-PACIFIC BIOCHEMICAL ENGINEERING CONFERENCE and $11^{\text {th }}$ ANNUAL MEETING OF THE THAI SOCIETY FOR BIOTECHNOLOGY. 1999, Phuket, Thailand. Resumo. Disponível em: http://www.cassava.org/Pub/1999/1999 05.htm. Acesso em: 16 abr. 2010.

WONG, D.W.S.; ROBERTSON, G.H. $\alpha$-Amylases. In: WHITAKER, J.R.; VORAGEN, A.G.H.; WONG, D.W.S. Handbook of Food Enzymology. New York, Marcel Dekker, 2003. cap. 56, p. 678-689.

WONG, D.W.S.; ROBERTSON, G.H. $\beta$-Amylases. In: WHITAKER, J.R.; VORAGEN, A.G.H.; WONG, D.W.S. Handbook of Food Enzymology. New York, Marcel Dekker, 2003b. cap. 57, p. 690-698.

WURZBURG, O.B. Modified Starches: properties and uses. Boca Raton: CRC Press, 1986. 277p. 